\title{
INVESTIGATION OF POTENTIALLY ACTIVE TECTONIC FAULTS ALONG THE ROUTE OF THE PROPOSED ALASKA STAND ALONE PIPELINE, LIVENGOOD TO COOK INLET, ALASKA
}

Rich D. Koehler, Richard D. Reger, Eleanor R. Spangler, and Alexander I. Gould

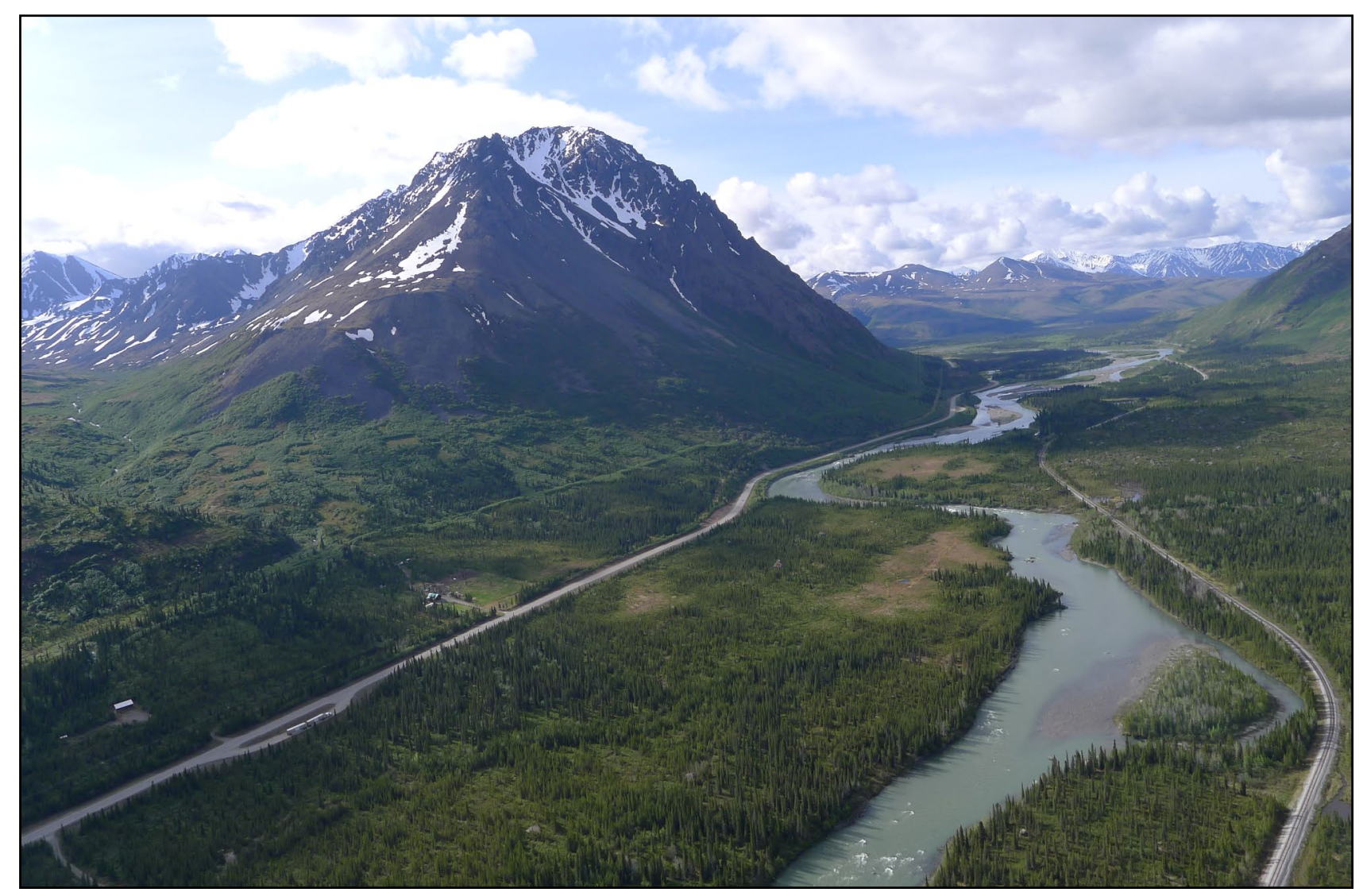

Aerial photograph of Panorama Mountain and the Nenana River, looking south along the proposed ASAP pipeline route. Photo by Rich Koehler.

April 2015

Published by

STATE OF ALASKA

DEPARTMENT OF NATURAL RESOURCES

DIVISION OF GEOLOGICAL \& GEOPHYSICAL SURVEYS

3354 College Road

Fairbanks, Alaska 99709-3707 

Report of Investigations 2015-4

INVESTIGATION OF POTENTIALLY ACTIVE TECTONIC FAULTS ALONG THE ROUTE OF THE PROPOSED ALASKA STAND ALONE PIPELINE, LIVENGOOD TO COOK INLET, ALASKA

\author{
Rich D. Koehler, Richard D. Reger, Eleanor R. Spangler, and Alexander I. Gould
}

\author{
Prepared for: \\ Alaska Gasline Development Corporation (AGDC) \\ 3201 C Street, Suite 200 \\ Anchorage, Alaska 99503
}

2015

$\$ 7.00$

This DGGS Report of Investigations is a final report of scientific research.

It has received technical review and may be cited as an agency publication. 


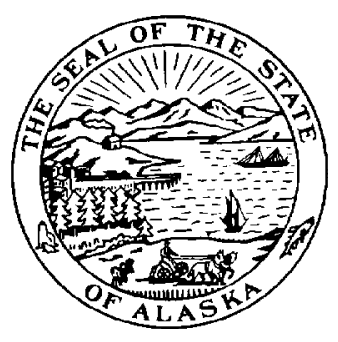

STATE OF ALASKA

Bill Walker, Governor

DEPARTMENT OF NATURAL RESOURCES

Mark D. Myers, Ph.D., Commissioner

DIVISION OF GEOLOGICAL \& GEOPHYSICAL SURVEYS

Steve Masterman, Director and State Geologist

Publications produced by the Division of Geological \& Geophysical Surveys (DGGS) are available for free download from the DGGS website (www.dggs.alaska.gov). Publications on hard-copy or digital media can be examined or purchased in the Fairbanks office:

\section{Alaska Division of Geological \& Geophysical Surveys 3354 College Rd., Fairbanks, Alaska 99709-3707 Phone: (907) 451-5020 Fax (907) 451-5050 \\ dggspubs@alaska.gov www.dggs.alaska.gov}

Alaska State Library

State Office Building, 8th Floor 333 Willoughby Avenue Juneau, Alaska 99811-0571

Elmer E. Rasmuson Library University of Alaska Fairbanks Fairbanks, Alaska 99775-1005
Alaska Resource Library \& Information Services (ARLIS)

3150 C Street, Suite 100

Anchorage, Alaska 99503-3982

University of Alaska Anchorage Library 3211 Providence Drive

Anchorage, Alaska 99508-4614

This publication released by the Division of Geological \& Geophysical Surveys was produced and printed in Fairbanks, Alaska. Publication is authorized by Alaska Statute 41, which charges the division "to determine the potential of Alaskan land for production of metals, minerals, fuels, and geothermal resources; the location and supplies of groundwater and construction materials; the potential geologic hazards to buildings, roads, bridges, and other installations and structures; and shall conduct such other surveys and investigations as will advance knowledge of the geology of Alaska." 


\section{CONTENTS}

1.0 EXECUTIVE SUMMARY..... 1

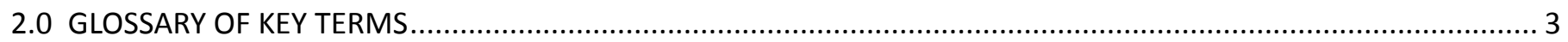

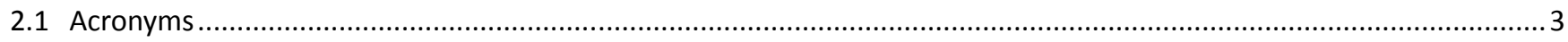

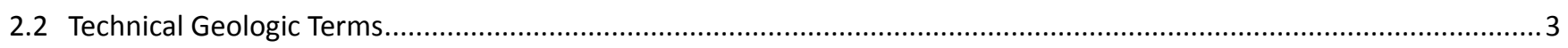

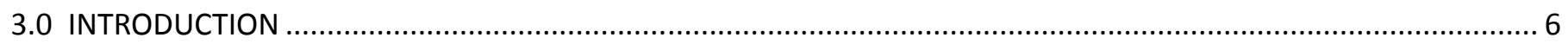

3.1 Purpose

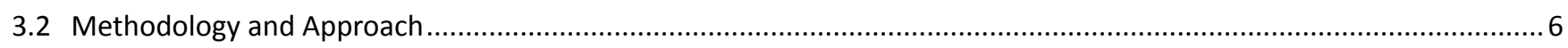

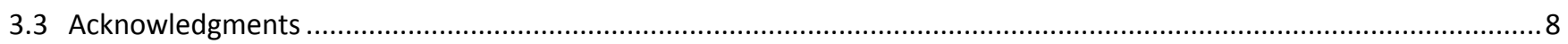

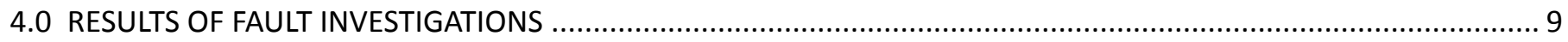

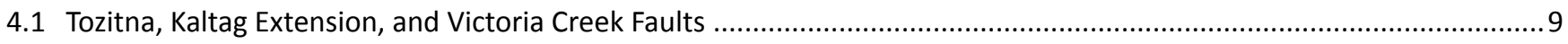

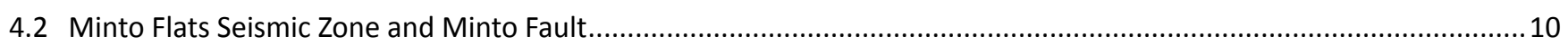

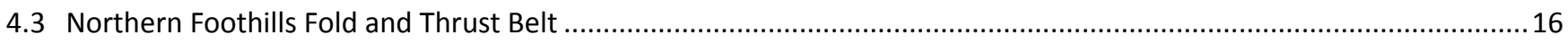

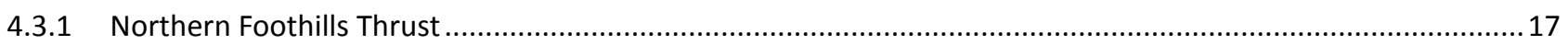

4.3.2 Backthrusts Associated with the Northern Foothills Thrust......................................................................21

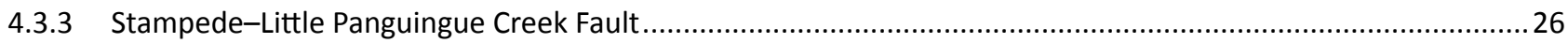

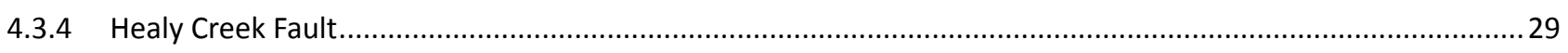

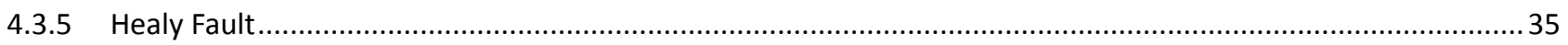

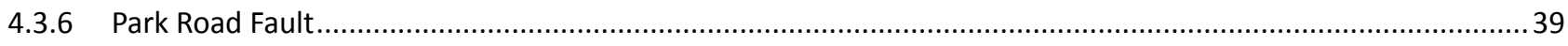

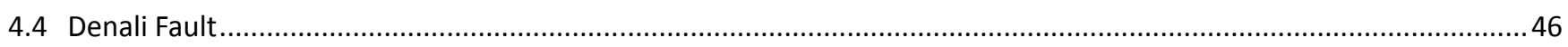

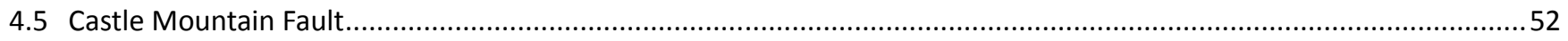

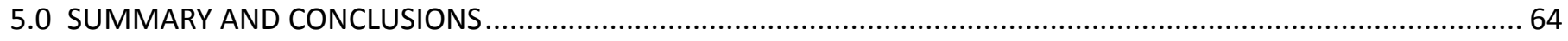

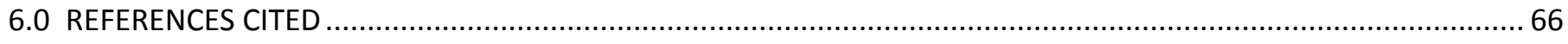

7.0 APPENDIX A References for previously-mapped faults shown on map figures ..............................................69

8.0 APPENDIX B Summary of laboratory results and calibration probability density functions for radiocarbon samples collected from trenches excavated across the Minto Fault, Northern Foothills backthrust faults, and the Castle Mountain fault......

\section{FIGURES}

Figure 1. Alignment of the proposed ASAP natural gas pipeline route from Prudhoe Bay to Cook Inlet .................................. 7

2. Regional fault map and lidar-derived hillshade maps for the Livengood vicinity, showing the active Kaltag, Tintina, Tozitna, Kaltag Extension, and Victoria Creek faults and other poorly understood faults .............................. 9

3. Topographic map and lidar hillshade, showing previous mapping of the Minto fault in the Minto Flats

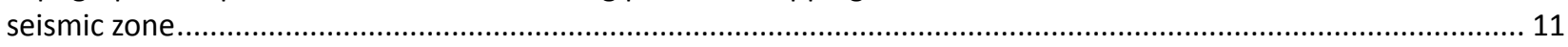

4. Geomorphic interpretation of lidar hillshade in the vicinity of the Minto fault ................................................... 12

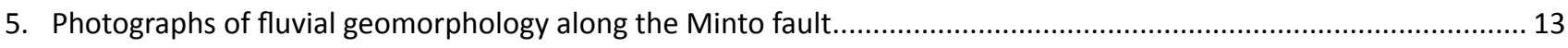

6. Original mapping of the Tanana River floodplain and Minto fault and satellite image, showing prominent meander channel margins in the vicinity of the Minto fault ........................................................................ 14

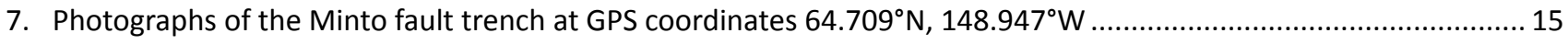

8. Stratigraphic log of trench MF-T-1 excavated across the Minto fault ................................................................... 15

9. Hillshade map of part of the western section of the Northern Foothills Fold and Thrust Belt, showing active faults of the Quaternary fault and fold database 
10. Cross section of the Northern Foothills Fold and Thrust Belt

11. Topographic map and lidar hillshade, showing previous fault mapping of the Northern Foothills thrust and mapping of associated backthrust faults south of the main trace in the vicinity of the proposed pipeline crossing. 18

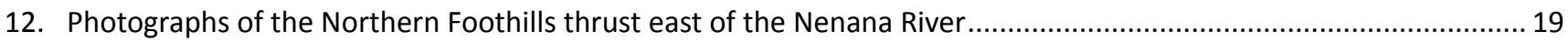

13. Photographs of the Northern Foothills thrust.....

14. Topographic profiles across the mapped trace of the Northern Foothills thrust and an active backthrust south of the main fault

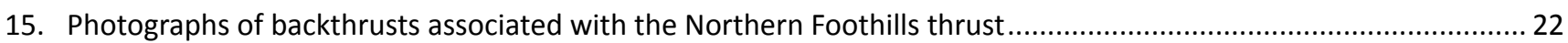

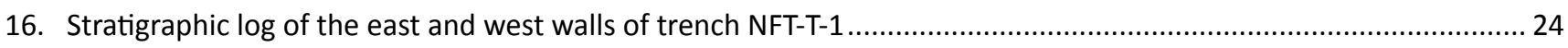

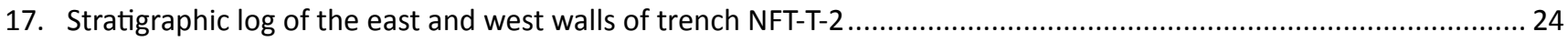

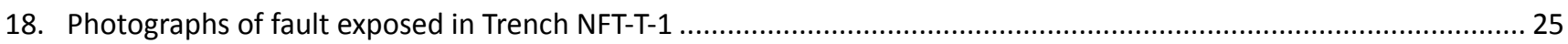

19. Topographic map and lidar hillshade, showing previously-mapped trace of the Stampede-Little Panguingue Creek fault and projection of the mapped trace toward the proposed pipeline route ........................................ 27

20. Helicopter photographs of the Stampede-Little Panguingue Creek fault .............................................................. 28

21. Topographic profiles across projected traces of the Stampede-Little Panguingue Creek fault ................................. 29

22. Topographic map and lidar hillshade (bottom), showing the mapped trace of the Healy Creek fault in the

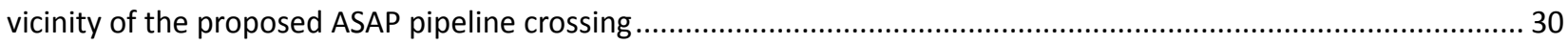

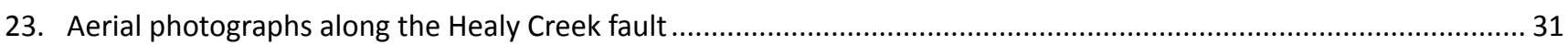

24. Surficial-geologic map of the Healy area, showing the Healy and Healy Creek faults and deposits discussed

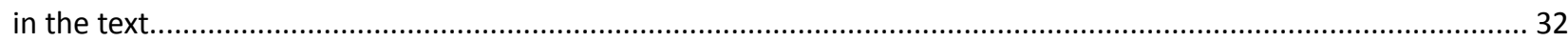

25. Topographic profiles across Healy-aged outwash terrace surface in the vicinity of the Healy Creek fault..................33

26. Topographic profiles across Riley Creek-aged outwash terrace surface in the vicinity of the mapped trace of Healy Creek fault.

27. Views to north of the Healy Creek and Stampede faults, showing uplifted surfaces directly west of the proposed pipeline route 35

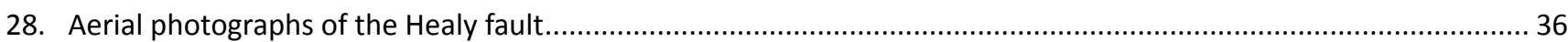

29. Topographic map and lidar hillshade, showing proposed pipeline route and previous mapping of the Healy fault.....

30. Healy fault scarp on the highest Riley Creek outwash surface

31. Topographic profiles across the projected trace of the Healy fault in the vicinity of the proposed pipeline route.

32. Tectonic geomorphology along the Park Road fault . 40

33. Topographic map and lidar hillshade map showing the mapped trace of the Park Road fault in the vicinity of the proposed ASAP pipeline crossing.

34. Lidar hillshade images of the Park Road fault, showing uninterpreted image and fault mapping performed for this project

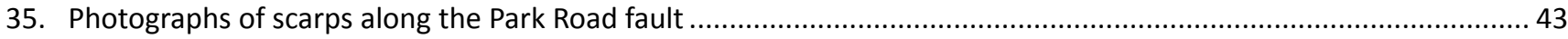

36. Lidar-generated topographic profiles of segments across the Park Road fault .....................................................44

37. Quaternary geologic map, showing the projection of the Park Road fault toward Lynx Creek crossing ....................45

38. Map of the Alaska Range, showing the extent of the western, central, and eastern sections of the Denali fault.

39. Topographic map and lidar hillshade, showing the mapped trace of the Denali fault in the vicinity of the Denali fault crossing...... 48

40. Photographs illustrating surface rupture patterns along the Denali fault 
41. Oblique air photo of the projection of the Denali fault across the forested Jack River alluvial valley in the vicinity of the proposed ASAP pipeline route

42. Lidar hillshade image of the Denali fault at the confluence of the Jack and Nenana rivers

43. Lidar hillshade image zoomed in to the Denali fault crossing, showing the preferred interpretation of the width of deformation marked by red-shaded rectangle.

44. Photographs of the Denali fault directly east of the Nenana River

45. Shaded relief map of south-central Alaska, showing the location of the Castle Mountain (CMF) and Denali faults.... 53

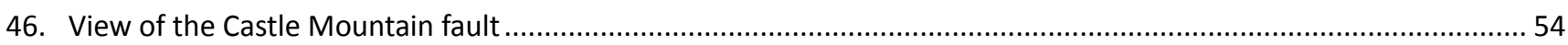

47. Lidar hillshade, DEM, and surficial-geologic map of the Castle Mountain fault

48. Topographic map and lidar hillshade, showing the mapped trace of the Castle Mountain fault in the vicinity of the proposed pipeline crossing

49. Topographic profile directly west of proposed pipeline crossing, showing originally flat sand plain surface at $36 \mathrm{~m}$ elevation that is warped into an anticline across the fault

50. Photos showing typical scarps along the Castle Mountain fault, with vertical displacement on the north side 58

51. Lidar hillshade, slope map, and 0.5-m-contour map for area west of proposed pipeline crossing, showing little lateral displacement of stream channel margins, left-stepping en echelon scarps, and width of deformation zone

52. Lidar hillshade, 0.5-m-contour topographic map, and photo of the Castle Mountain fault trench sites

53. Photographs of faulted fluvial stratigraphy from the Castle Mountain fault trenches

54. Stratigraphic log of the east and west walls of trench CMF-T-1.

55. Stratigraphic logs of the east and west walls of trench CMF-T-2

\section{TABLES}

Table 1. Summary of results for active or potentially active faults that cross or project toward the proposed ASAP pipeline route.

2. Summary of fault rupture parameters for proposed ASAP pipeline route fault crossings. 



\title{
INVESTIGATION OF POTENTIALLY ACTIVE TECTONIC FAULTS \\ ALONG THE ROUTE OF THE PROPOSED ALASKA STAND ALONE PIPELINE, LIVENGOOD TO COOK INLET, ALASKA
}

\author{
Rich D. Koehler ${ }^{1}$, Richard D. Reger ${ }^{2}$, Eleanor R. Spangler ${ }^{1}$, and Alexander I. Gould ${ }^{1}$
}

\subsection{EXECUTIVE SUMMARY}

This report presents the results of an evaluation of potentially active faults in south-central and interior Alaska that could intersect the alignment of the proposed Alaska Stand Alone Pipeline (ASAP) project being considered by the Alaska Gasline Development Corporation (AGDC). The purpose of this report is to summarize the relative tectonic activity (active, potentially active, not active) of each structure of concern, determine fault rupture parameters, and delineate the locations of possible fault/pipeline crossings on maps. The proposed pipeline route extends from Prudhoe Bay to northern Cook Inlet. This report focuses on the southern part of the proposed route that runs from the vicinity of Livengood to the Susitna lowland, generally paralleling the Parks Highway southward from the Nenana basin.

Twelve faults or fault systems that potentially intersect the proposed pipeline route were identified based on evaluation of existing data and imagery, helicopter reconnaissance, and field investigations. The faults include the Tozitna, Kaltag Extension, and Victoria Creek faults, the Minto Flats seismic zone (Minto fault), the Northern Foothills thrust and associated backthrust faults, and the Stampede-Little Panguingue Creek, Healy Creek, Healy, Park Road, Denali, and Castle Mountain faults. Table 1 summarizes the relative activity of each fault investigated in this report, its crossing location on the current route, whether the fault is well defined at the crossing location, style of deformation, single event displacement estimate, and recurrence.

Earthquake hazard studies typically consider faults to be active if they have generated surface displacement during the Holocene (the last $\sim 11,500$ years). In this investigation, faults are considered active if they deform Holocene deposits. In areas lacking Holocene deposits or with long recurrence intervals along some structures, faults were subject to investigation if they displaced or warped the surface of late Pleistocene ( 11,500 to 1.8 million years BP) deposits.

The Castle Mountain, Denali, and Park Road faults all displace Holocene deposits and are clearly active. These faults potentially pose major surface fault rupture hazards to the proposed pipeline. The location of the Denali fault is associated with a wide zone of uncertainty due to burial of the surface trace by late Holocene deposition in the Jack River valley. However, the Denali fault is well defined east of the Nenana River. Several subsidiary parallel strands of the fault have not been investigated on the ground, and warrant further inspection.

The Healy and Healy Creek faults are considered potentially active and could possibly displace late Pleistocene deposits east of the proposed pipeline route. These faults have been considered active in previous studies; however, neither structure deforms deposits where they cross or project toward the proposed pipeline route. The Healy Creek fault does not displace Holocene deposits, and is eliminated from consideration. Additional trenching studies are recommended along the Healy fault to determine whether this fault is Holocene active and to better define fault rupture parameters.

The Northern Foothills thrust is associated with large displacements of Holocene alluvial fans east of the proposed pipeline route and is considered active. Its location relative to the route of the proposed pipeline is indeterminate. Backthrusts associated with the Northern Foothills thrust are active and comprise a broad zone of multiple splays that warp and displace the surface of a late Pleistocene fluvial terrace where the backthrusts cross the proposed pipeline route.

The Tozitna, Kaltag Extension, Victoria Creek, Minto, and Stampede-Little Panguingue faults were eliminated from consideration because they are not considered to represent active surface fault rupture hazard and/or do not cross the proposed pipeline route.

\footnotetext{
${ }^{1}$ State of Alaska, Department of Natural Resources, Division of Geological \& Geophysical Surveys (DGGS), 3354 College Rd., Fairbanks, Alaska 99709; rich.koehler@alaska.gov

${ }^{2}$ Reger's Geologic Consulting, P.O. Box 3326, Soldotna, AK 99669
} 
Table 1. Summary of results for active or potentially active faults that cross or project toward the proposed ASAP pipeline route.

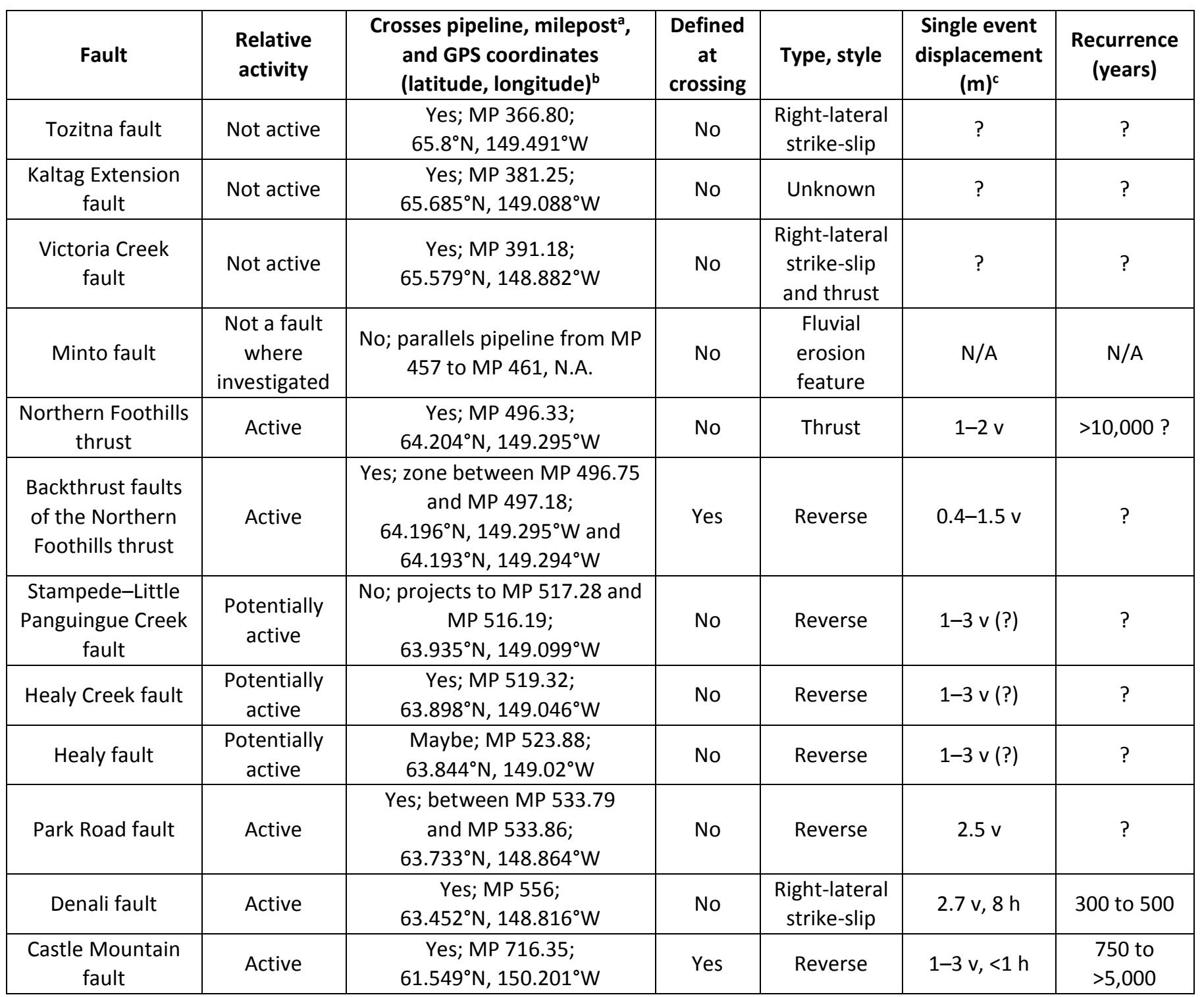

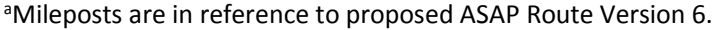

${ }^{b}$ GPS coordinates of the pipeline route crossing are based on the mapped trace of the fault and do not represent the total width of deformation, which is described in the text. In cases where the fault does not extend across the route, the coordinates of the crossing are based on projection of the fault from east or west of the route. Coordinate system is NAD 1983.

ch, horizontal; v, vertical; N/A, not applicable. For Northern Foothills thrust, displacement is based on the scarp shown on figure $13 B$, which is $3 \mathrm{~m}$ high and has an oversteepened base, suggesting it was formed by more than one event. For the Denali fault, displacement is based on the maximum horizontal displacement that occurred in the 2002 Denali fault earthquake. For the Stampede-Little Panguingue Creek, Healy Creek, and Healy faults estimated displacements are based on surface scarps along the Healy fault and not directly observed in subsurface exposures. 


\subsection{Acronyms}

AGDC: Alaska Gasline Development Corporation

AHAP: Alaska High Altitude Photography

ASAP: Alaska Stand Alone Pipeline

DEM: Digital Elevation Model

DGGS: Division of Geological \& Geophysical Surveys

MFSZ: Minto Flats Seismic Zone

NFFTB: Northern Foothills Fold and Thrust Belt

SPCO: State Pipeline Coordinator's Office

TAPS: Trans Alaska Pipeline System

\subsection{Technical Geologic Terms}

${ }^{10}$ Be surface-exposure dating: A geochronological technique for estimating the length of time that a rock has been exposed at the earth's surface using cosmogenic radionuclide dating of beryllium-10.

active fault: A fault that has generated displacement during the Holocene epoch (the last 11,500 years).

angular unconformity: An unconformity between two groups of rocks whose bedding planes are not parallel or in which the older, underlying rocks dip at a different angle (usually steeper) than the younger, overlying strata.

anticline: A fold, generally convex upward, whose core contains the stratigraphically older rocks.

backthrust: A thrust fault in a fold-thrust belt that dips opposite to the general dip of the master fault and results in displacement back toward the hinterland of the fold-thrust belt.

basal detachment thrust fault: A low-angle thrust fault forming the base of a thrust sheet; also, the basal main fault of an imbrication.

blind fault: A fault that does not appear at the Earth's surface as an outcrop.

BP: Before present (with "present" fixed as the year 1950). Commonly used as "yBP", or years before present.

brecciated: Converted into, characterized by, or resembling a breccia; esp. said of a rock structure marked by an accumulation of angular fragments, or of an ore texture showing mineral fragments without notable rounding.

deformation: The change in the geometry of a body of rock that occurs as a consequence of faulting, shearing, or fabric development of the rocks.

dextral slip: Movement on a strike-slip fault on which the side opposite the observer has been displaced to the right. Also called right-lateral slip.

dip: The maximum angle that a structural surface, such as bedding or a fault plane, makes with the horizontal; measured perpendicular to the strike of the structure and in the vertical plane.

dip-slip fault: A fault on which the movement is parallel to the dip of the fault.

displacement: The relative movement of the two sides of a fault, measured in any chosen direction; also, the specific amount of such movement.

drag fold: A minor fold, formed due to shear resulting from slip on a fault.

en echelon: Geologic features that are in an overlapping or staggered arrangement and are systematically offset in either a left-stepping or right-stepping manner. Each is relatively short but collectively they form a linear zone in which the strike of the individual features is oblique to that of the zone as a whole.

escarpment: A long, more or less continuous cliff or relatively steep slope facing in one general direction, breaking the continuity of the land by separating two level or gently sloping surfaces, and produced by erosion or faulting.

fault: A discrete surface or zone of discrete surfaces separating two rock masses along which one mass has slid past the other.

fault crossing: The location where a fault crosses the proposed pipeline route.

fault rupture: Brittle deformation due to a momentary loss of cohesion or loss of resistance to differential stress and a release of stored elastic energy. 
fault scarp: A topographic escarpment formed directly by movement along a fault and representing the exposed surface of the fault before modification by erosion and weathering. It is an initial landform.

fault slip: The relative displacement of formerly adjacent points on opposite sides of a fault, measured in the fault surface.

fault strand: An individual fault of a set of closely-spaced parallel or subparallel faults of a fault system.

fault trace: The intersection of a fault plane with the ground surface or with a reference plane.

fault zone: A fault that is expressed as a zone of numerous faults, small fractures, breccia, and/or fault gouge. A fault zone may be as wide as hundreds of meters.

fissure: A surface of fracture or a crack in rock along which there is a distinct separation.

flexural slip folding: A flexure fold in which the mechanism of folding is slip along bedding planes or along surfaces of foliation. There is no change in thickness of individual strata, and the resultant folds are parallel.

flexural slip: Slip between rock layers during flexural folding of a multilayered sequence. Slip occurs on discrete surfaces.

footwall: The underlying side of a fault; especially the wall rock beneath an inclined fault.

fold: A curve or bend of a planar structure such as rock strata, bedding planes, foliation, or cleavage. A fold is usually a product of deformation.

graben: An elongate trough or basin, bounded on both sides by high-angle normal faults that dip toward one another.

hanging wall: The overlying side of a fault; especially the wall rock above an inclined fault.

Holocene: The latest Epoch of the Quaternary Period, younger than the Pleistocene Epoch, covering the time span between $11.5 \mathrm{ka}$ and the present.

ka: Kilo-annum, one thousand $\left(10^{3}\right)$ years. Informal SI notation, where annum is age in years before present, with "present" fixed as 1950.

left-lateral fault: A strike-slip fault on which the side opposite the observer has been displaced to the left. Also called "sinistral" fault.

lineament: A linear topographic feature of regional extent that may or may not reflect crustal structure.

Ma: Mega-annum, one million $\left(10^{6}\right)$ years. Informal SI notation, where annum is age in years before present, with "present" fixed as 1950.

mole track: A small, geologically short-lived ridge, typically $30 \mathrm{~cm}$ to several meters high, formed by displacement and cracking of the ground by strike-slip fault movement in alluvial and/or colluvial materials. It resembles the track of a mole, or a line of disturbed earth turned by a plow.

moment magnitude: The moment magnitude scale (denoted as $\mathrm{M}_{\mathrm{w}}$ or $\mathrm{M}$ ) is used by seismologists to measure the size of earthquakes in terms of the energy released. The scale was developed in the 1970s to succeed the 1930s-era Richter "local magnitude" scale $\left(\mathrm{M}_{\mathrm{L}}\right)$. Other magnitude scales include body $\left(\mathrm{M}_{\mathrm{b}}\right)$ and surface wave $\left(\mathrm{M}_{\mathrm{S}}\right)$.

monocline: A local steepening in an otherwise uniform gentle dip.

non-active fault: A fault that has not deformed Holocene (the last 11,500 years) deposits.

normal fault: A fault in which the hanging wall has moved downward relative to the footwall. The angle of the fault is usually $45^{\circ}-90^{\circ}$, and in most cases close to $60^{\circ}$.

oblique fault: A fault on which the net slip has dip-slip and strike-slip components.

offset: The separation on a fault as observed in the plane of an outcrop or cross section. Also, the displacement of a geomorphic feature laterally or vertically by faulting.

Paleocene: The oldest Epoch of the Paleogene sub-Period of the Tertiary Period, younger than the Cretaceous Period and older than the Eocene Epoch. Covers the time span between 65.5 and 55.8 Ma.

paleoseismic studies: Investigations of or pertaining to prehistoric seismic events. Typically the study of geologic sediments and rocks, for signs of ancient earthquakes, used to complement seismic monitoring, for the calculation of seismic hazard.

Pleistocene: The older Epoch of the Quaternary Period, younger than the Pliocene Epoch of the Tertiary Period and older than the Holocene Epoch. Covers the time span between 1.8 Ma and $11.5 \mathrm{ka}$.

potentially active fault: A fault that displaces or warps the surface of late Pleistocene ( 11,500 to 1.8 million years BP) landforms, but is not associated with deformation of the Holocene (the last 11,500 years) deposits.

Precambrian: A commonly used term to designate all rocks older than the Cambrian. It includes the Archean and Proterozoic Eons and represents 90 percent of geologic time. Covers the timespan between $\sim 4,600 \mathrm{Ma}$ and $542 \mathrm{Ma}$.

pressure ridges: A seismic feature caused by transverse pressure and shortening of subsurface materials. Results in a hill landform on the surface.

Quaternary: The latest Period of the Cenozoic Era, younger than the Tertiary Period. Covers the timespan between $1.8 \mathrm{Ma}$ and the present. 
reverse fault: A fault on which the hanging wall has moved upward relative to the footwall. The dip of the fault is usually greater than $45^{\circ}$.

right-lateral fault: A strike-slip fault on which the side opposite the observer has been displaced to the right. Also called a "dextral" fault.

sag depressions: A depression produced by downwarping of the ground surface on the downthrown side of a fault. These depressions are commonly closed (sag ponds).

separation: The distance, measured in a specified direction, between two once-adjacent points on an index plane (for instance, a surface, bed, or vein) disrupted by a fault.

shear zone: A tabular zone of rock that has been brecciated by many parallel faults and fractures.

shutter ridge: A topographic ridge that has been transported by movement on a strike-slip fault to block an existing topographic valley, deflecting drainages and/or streams.

sinistral slip: Movement on a strike-slip fault on which the side opposite the observer has been displaced to the left. Also called left-lateral slip.

splay (also fault splay): A minor fault that branches off of a larger fault. Commonly, major faults partition into an array of splays.

strain: The change in shape and/or size of a body. Strain is the non-rigid component of deformation.

strike: The direction or trend taken by a structural surface, such as a bedding or fault plane, as it intersects the horizontal.

strike-slip fault: A fault on which the movement is parallel to the fault's strike.

subsidence: The sudden sinking or gradual downward settling of the Earth's surface with little or no horizontal motion. The movement is not restricted in rate, magnitude, or area involved. Subsidence may be caused by natural geologic processes, such as solution (karst phenomena), thawing, compaction, slow crustal warping, or withdrawal of fluid lava from beneath a solid crust; or by man's activity, such as subsurface mining or the pumping of oil or groundwater.

syncline: A fold in which the core contains the stratigraphically younger rocks; it is generally concave upward.

tectonic: Of, or relating to, the structure of the Earth's crust and the large-scale processes that take place within it.

tectonic landform: A landform produced by earth movements, including any topographic features produced by lateral offset, uplift, or subsidence of the Earth's crust.

Tertiary: The oldest Period of the Cenozoic Era, younger than the Cretaceous Period and older than the Quaternary Period. Subdivided into the Paleogene and Neogene sub-Periods. Covers the timespan between 65.5 and $1.8 \mathrm{Ma}$.

thaw basin: A hollow in the ground resulting from subsidence following the local melting of ground ice in permafrost regions.

thrust fault: A fault with a dip of $45^{\circ}$ or less over much of its extent, on which the hanging wall has moved upward relative to the footwall.

uplift: A structurally high area in the crust, produced by positive movements that raise or upthrust the rocks, as in a dome or arch. 
Under the authority of the 26th Alaska State Legislature's House Bill 369, the Alaska Gasline Development Corporation (AGDC) began conducting environmental and engineering studies in 2010 to facilitate planning, development, design, and potential construction of the Alaska Stand Alone Pipeline (ASAP) project (fig. 1). The goal of the ASAP project is to provide a long-term, reliable, and affordable energy source for Alaska communities. The project plan includes the development of a $\sim 730$-mile-long, 36 -inch-diameter natural gas pipeline between Alaska's North Slope and the Cook Inlet area in south-central Alaska as well as lateral lines to Fairbanks and other communities where feasible. The project also includes development of a gas-conditioning facility in Prudhoe Bay and a compressor station on the North Slope.

The proposed pipeline route traverses challenging topography and is exposed to a wide variety of geologic hazards including, but not limited to, active faulting, earthquake ground shaking, liquefaction, landslides, rockfall, permafrost, frost heaving, aufeis, and flooding. Understanding these hazards is fundamental to appropriate pipeline route selection, design, and construction. To address these concerns, the State of Alaska, Division of Geological \& Geophysical Surveys (DGGS) conducted geologic reconnaissance and paleoseismic studies to identify geologic hazards along the entire proposed pipeline route during the 2011, 2012, and 2013 field seasons. Additional site-specific studies along active faults south of Livengood were conducted during the 2014 field season. The investigations were conducted in accordance with proposals and reimbursable services agreements (RSAs) with AGDC and the State Pipeline Coordinator's office (SPCO).

\subsection{Purpose}

The purpose of this report is to summarize the results of the 2013-2014 site-specific fault studies and outline potential impacts to the proposed pipeline route alignment. The report provides information on the relative tectonic activity (active, potentially active, not active) of each structure of concern, details faulting parameters, and uses maps to outline the limits of possible fault/pipeline crossing locations. Additionally, for Holocene-active faults for which sufficient information exists to constrain potential rupture length, we report estimates of potential future earthquake magnitude based on empirical relations in Wells and Coppersmith (1994). Details on the neotectonic setting and regional geology of the proposed pipeline route are summarized in the published literature and field guidebooks (for example: Freymueller and others, 2008; Mull and Adams, 1989) and not provided in this report.

This report is organized into three sections: Methodology and Approach, Results of Fault Investigations, and Summary and Conclusions. Quantitative measurements are reported in metric units except in reference to locations along the proposed pipeline route, which are reported in miles. The majority of the figures are focused on the vicinity of the proposed pipeline route, thus not all references to geographic place names are shown on figures. These locations are shown on maps referenced in the report.

\subsection{Methodology and Approach}

Our investigative approach was designed to identify and characterize locations and displacement parameters of active and potentially active faults that could pose a geohazard to the pipeline due to surface fault rupture and/or surface deformation. In preparation for field studies, we compiled and reviewed pertinent published and unpublished geologic maps, reports, professional journals, and aerial photographs and imagery. Air photos examined during this study include stereo color-infrared photos ( 1:65,000 scale) from NASA Ames Research Center's Alaska High Altitude Photography (AHAP) collection acquired from the University of Alaska Fairbanks and the U.S. Geological Survey's EarthExplorer website. Additionally, black and white stereo air photos ( 1:25,000 scale) along the Denali fault that are archived at DGGS were evaluated. Satellite imagery evaluated included Google Earth and LandSat images available through ArcGIS online.

Lidar coverage provides the most precise available model of the earth's topography and is now the industry standard for geologic and seismic hazard assessments. In anticipation of several proposed pipeline and other infrastructure projects, DGGS acquired high-resolution lidar data for the major transportation corridors in the state, including most of the current selected route of the proposed ASAP project (Hubbard and others, 2011). We generated digital elevation models (DEMs) and hillshade images of a $\sim 2$-km-wide swath generally centered on the proposed ASAP pipeline route (version V6 provided by AGDC). Several expanded sections of lidar data were acquired for areas outside of the alignment corridor to allow investigation of active faults. The lidar coverage was particularly useful in identifying fault location and surficial deposits used to assess relative fault activity. Air photo, satellite imagery, and lidar observations were compiled on topographic base maps and used in the field investigations. Between Nenana and Rex, the proposed pipeline route deviates from the lidar coverage, limiting our observation of this area. 


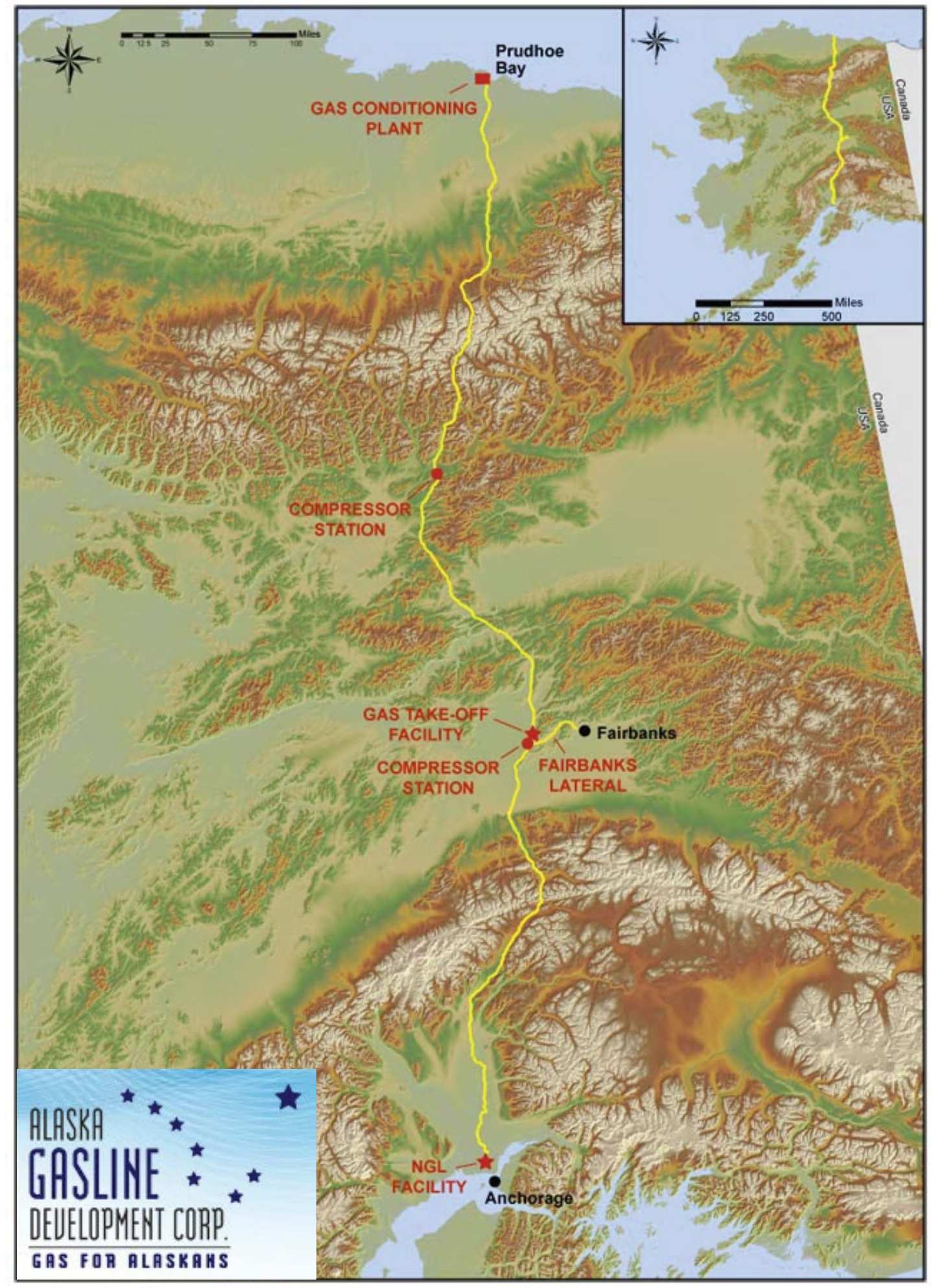

Figure 1. Alignment of the proposed ASAP natural gas pipeline route from Prudhoe Bay to Cook Inlet. Figure from Alaska Gasline Development Corp. website: http://asapgas.agdc.us/. 
Helicopter reconnaissance is the most efficient and effective method for evaluating the landscape over large areas; it provides the opportunity to view tectonic features from different altitudes and angles not possible with traditional air photo evaluation. We performed helicopter reconnaissance along the entire proposed pipeline route alignment and adjacent areas from Prudhoe Bay to Cook Inlet. Our literature review, imagery evaluation, and map compilation were used to guide helicopter reconnaissance surveys. The primary focus of the helicopter reconnaissance was to verify imagery observations, identify faults, evaluate their extent in the vicinity of the proposed pipeline route, and identify evidence of activity or inactivity. Faults that show evidence of slip displacement during the Holocene Epoch (approximately the past 11,500 years) are relevant to the design of the ASAP pipeline.

Based on our air photo/imagery and helicopter observations, we identified sites for detailed site-specific ground studies along faults. The ground studies were designed to map geomorphology and surficial deposits, identify specific crossing locations, and define fault displacement parameters. Specific fault parameters assessed include style of faulting, width and geometry of the fault and zone of deformation, dip angle of the fault in the shallow subsurface, fault orientation (strike), amount and direction of single-event displacement, and recurrence interval. For thrust faults, the amount and geometry of folding at the fault/pipeline crossing were also assessed. Fault scarp profiles were generated from lidar data and field observations to assess scarp height, evidence for multiple surface-rupturing earthquakes, and the near-surface geometry of subsurface structures.

Site-specific field investigations were conducted along nine active or potentially active faults in the proposed pipeline route alignment including, from north to south, the Minto fault, the Northern Foothills thrust and associated backthrust faults, and the Stampede-Little Panguingue Creek, Healy Creek, Healy, Park Road, Denali, and Castle Mountain faults. Limited reconnaissance surveys were conducted in the vicinity of Livengood along previously mapped faults including the Tozitna, Kaltag Extension, and Victoria Creek faults. Because these faults are poorly defined and do not deform Holocene sediments, site-specific ground investigations were not conducted on these structures.

Trenching is the most effective paleoseismic technique to evaluate surface fault rupture hazards. Trenches are particularly useful for delineating precise locations of active faults, defining additional fault splays that might not be expressed on the surface, and assessing fault-displacement parameters. In Alaska, logistical challenges in mobilizing equipment to field sites can mean that trenching is not always feasible. Five trenches were excavated for this project, including one across the Minto fault, two across backthrust splays of the Northern Foothills thrust, and two across the Castle Mountain fault.

\subsection{Acknowledgments}

DGGS acknowledges the logistical and technical support provided by Mr. Bill Burgess of Michael Baker, Inc., which contributed significantly to the successful outcome of the project. We also acknowledge assistance in the field by Dr. Trent Hubbard and Ms. Rachel Frohman of DGGS, Dr. Rob Witter of the U.S. Geological Survey, Dr. Gary Carver of Carver Geologic, Inc., Dr. Tony Crone of PaleoEarthquake International, LLC, and Patrick Beauchesne of WorleyParsons Ltd. Discussions of project objectives by Mr. Dave Norton, Mr. Frank Richards, Mr. Keith Meyer, and Mr. Dave Haugen of AGDC were helpful in guiding project tasks. We are grateful for safe transport to remote field localities by Pathfinder Aviation, Inc., Prism Helicopters, and Quicksilver Air, Inc. We appreciate prompt delivery of fuel to field base camps by Alaska Aerofuel, Inc., and careful excavation of trenches by Clear Excavating, Inc., of Wasilla and Tangent \& Taper Construction of Fairbanks. 
The results of fault investigations are described below from north to south. The investigations include observations from the Tozitna, Kaltag Extension, and Victoria Creek faults, the Minto Flats Seismic Zone and Minto fault, faults of the Northern Foothills fold and thrust belt, and the Denali and Castle Mountain faults. Supporting maps and figures are provided for each fault or fault system studied.

\subsection{Tozitna, Kaltag Extension, and Victoria Creek Faults}

In the vicinity of Livengood, three major faults cross the pipeline route including the Tozitna, Kaltag Extension, and Victoria Creek faults (Weber and others, 1992) (fig. 2). All three of these faults extend for more than $110 \mathrm{~km}$ at an orientation of 245-255 degrees and have been depicted on cross sections with vertical dips (Weber and others, 1992). Together, these faults represent the western extension of the Tintina fault system and might connect with the Kaltag fault to the west. The Kaltag and Tintina faults are considered to be mid-Quaternary to Holocene active, respectively (Koehler and others, 2012a; Foster and others, 1983; Patton and Hoare, 1968), and both have generated historic moderate $M>5$ earthquakes (Gedney and others, 1972). These two fault systems together constitute a major right-lateral fault system that extends over 600 miles across central Alaska in an arcuate east-west direction. Because the Tozitna, Kaltag Extension, and Victoria Creek faults could play a role in transferring slip between the Kaltag and Tintina faults, we performed limited helicopter reconnaissance and lidar inspection of these faults in the vicinity of the pipeline route to evaluate their relative activity.

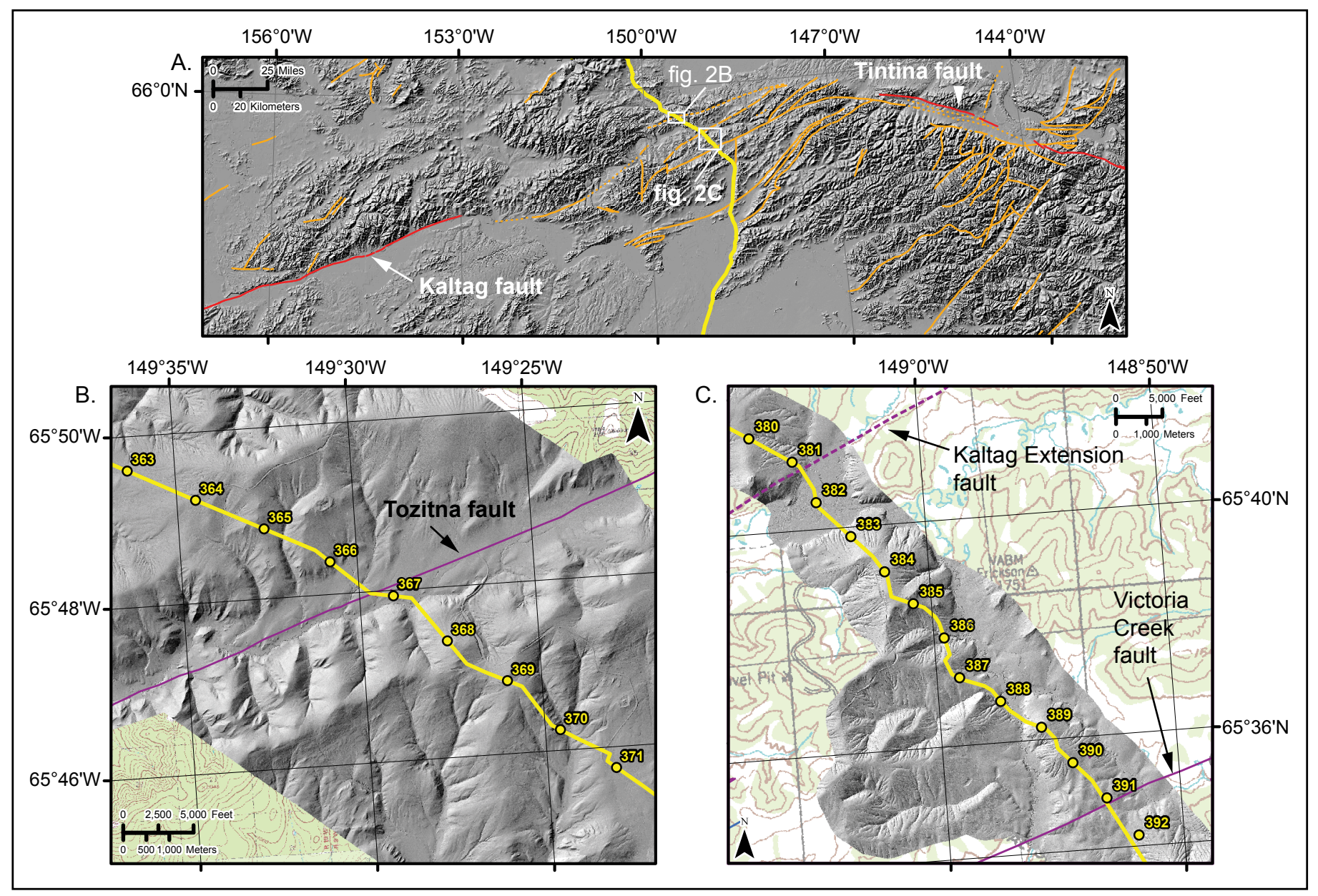

Figure 2. A. Regional fault map for the Livengood vicinity, showing the active Kaltag and Tintina faults (red lines) and other poorly understood faults (orange lines). References for mapped faults are listed in Appendix A. Areas of maps $B$ and $C$ are outlined by white boxes. B. Lidar-derived hillshade map, showing the location of the Tozitna fault (MP $366.80 ; 65.8^{\circ} \mathrm{N}, 149.491^{\circ} \mathrm{W}$ ). C. Lidar-derived hillshade map, showing the location of the Kaltag Extension fault (MP $381.25 ; 65.685^{\circ} \mathrm{N}, 149.088^{\circ} \mathrm{W}$ ) and Victoria Creek fault (MP $391.18 ; 65.579^{\circ} \mathrm{N}, 148.882^{\circ} \mathrm{W}$ ). Proposed pipeline route and mileages shown in bold yellow on each map. 
The Tozitna fault extends along the linear drainages of Isom and Rodgers creeks and merges with the western projection of the Tintina fault in the vicinity of Granite Creek near the southern margin of the Yukon Flats. Weber and others $(1992,1997)$ map the Tozitna fault as concealed along most of its length, but indicate right-lateral motion. The Tozitna fault crosses the proposed pipeline route at MP $366.80^{3}$ (fig. $2 \mathrm{~B}$ ). There the fault is associated with several triangular facets along the southern canyon wall of Isom Creek. Inspection of lidar hillshade images and helicopter reconnaissance indicates that the Tozitna fault is concealed beneath frozen, ice-rich, retransported silts and upland loess of probable late Pleistocene age in the Isom Creek valley. Youthful tectonic geomorphic features (such as offsets or scarps) are not developed along the mapped trace of the fault, which leads us to conclude that the Tozitna fault is not Holocene active in the vicinity of the proposed pipeline crossing. However, we cannot preclude Holocene activity east of the area we investigated.

The Kaltag Extension fault extends from near Granite Creek on the east to the vicinity of Raven Creek Hill on the west where it merges with the Kaltag fault. Tectonic geomorphology along the Kaltag Extension fault includes elongate, linear bedrock ridges and several saddles. Weber and others (1992) map the Kaltag Extension fault as concealed and questioned along most of its length, and do not indicate a sense of motion; however, Weber and others (1997) show the fault as inferred. The Kaltag Extension fault crosses the proposed pipeline route at MP 381.25 (fig. 2C) and extends across a gently south-sloping ridge between Mastodon Creek and Fish Creek east of the route. Tectonic geomorphic features are not evident on the limited lidar coverage, from which we infer that the fault has not produced surface deformation in the Holocene. The Kaltag Extension fault was not investigated along its projection to the east or west of the lidar coverage.

The Victoria Creek fault extends from the Sawtooth Mountains area in the west to the upper headwaters of Victoria Creek in the east where it merges with the Tintina fault. Weber and others (1992) show the fault as a right-lateral strike-slip fault but depict it as concealed over much of its length. Weber and others (1997) show an approximately 20-km-long section of the fault near the Sawtooth Mountains as a south-dipping thrust fault. We inspected more than $60 \mathrm{~km}$ of the fault by helicopter east of the proposed pipeline route where it follows several aligned broad, linear valleys separated by low saddles, including the drainages of upper Erickson, Wolf, Bear, and Victoria creeks. A large bedrock shutter ridge noted in the Victoria Creek drainage is consistent with strike-slip displacement. Small-scale tectonic scarps were not observed along the mapped trace of the fault, and Holocene deposits are not deformed where they cross the fault. The Victoria Creek fault crosses the proposed pipeline route at MP 391.18 (fig. 2C) where it is concealed beneath frozen, ice-rich loess. The surface of the ice-rich loess is smooth and unbroken, and we did not observe tectonic geomorphic features that would indicate Holocene displacement, consistent with our helicopter observations to the east. Therefore we conclude that the Victoria Creek fault is not a Holocene-active fault in the vicinity of the pipeline route, and we eliminate it from consideration.

\subsection{Minto Flats Seismic Zone and Minto Fault}

The Minto Flats seismic zone (MFSZ) is one of several active, north-northeast-trending, left-lateral, strike-slip seismic zones that extend north of the Northern Foothills Fold and Thrust Belt. The MFSZ is associated with two distinct lineaments of seismicity that define the boundaries of the 7-km-deep Nenana Basin (Tape and others, 2013). The southeastern lineament coincides with a 20-km-long, down-to-the-northwest lineament along the Tanana River floodplain from Goldstream Creek to near Dunbar, which is mapped as a fault by Péwé and others (1966) and subsequently named the Minto fault by Gedney and others (1972). A topographic escarpment with subtle cuspate morphology in map view extends for several kilometers along the southern part of the mapped fault trace. This escarpment is attributed by Brogan and others (1975) to active faulting; however, Page and others (1995) suggest that the escarpment is a terrace riser of the Nenana River.

The MFSZ has been the source of numerous earthquakes felt in the Fairbanks area; the largest event was the 1995 M 6.0 Minto Flats earthquake. A M 5.1 earthquake occurred August 30, 2014, in the northern part of the zone and generated a vigorous aftershock sequence of more than 1,500 events, including two events $>$ M 4 (AEC, 2014). These events are dominantly sourced deep in the crust, and tectonic geomorphic evidence for active tectonics at the surface, such as progressively offset landforms and triangular facets along the basin margin, are absent aside from the possible tectonic escarpment near Goldstream Creek. No previous paleoseismic studies have been conducted along the fault.

The feature referred to as the Minto fault ${ }^{4}$ extends roughly parallel and very close to the proposed ASAP pipeline route in the vicinity of MP 458 (fig. 3), and thus a detailed investigation was warranted to re-evaluate the origin of the scarp and assess its tectonic potential. We performed helicopter reconnaissance and an assessment of the local geomorphology; we also excavated a paleoseimic trench across the mapped trace of the Minto fault in the vicinity of Little Goldstream Creek.

\footnotetext{
${ }^{3}$ All milepost measurements used in this report are in reference to ASAP Route Version 6.

${ }^{4}$ Referred to in this report as the "Minto fault", although it has not been proven to be a fault.
} 
Inspection of lidar hillshade imagery indicates that the mapped trace of the Minto fault is coincident with a scarp that marks the boundary between thick alluvial-colluvial silt deposits to the east and Tanana River floodplain deposits to the west (figs. 4 and 5A). The scarp extends into the relatively older part of the alluvial fan deposited by Little Goldstream Creek but does not continue across the relatively younger part of the fan to the southwest. Small bluff-head sand dunes are present along the crest of the scarp, and a large belt of sand dunes was observed across the scarp near Little Goldstream Creek. North of the mapped trace of the fault, sinuous fluvial meander channels on the Tanana River floodplain cut across the fault and might have eroded and removed the escarpment (figs. 4 and 5B). Figure 6 presents previous mapping of the Tanana River floodplain and a modern

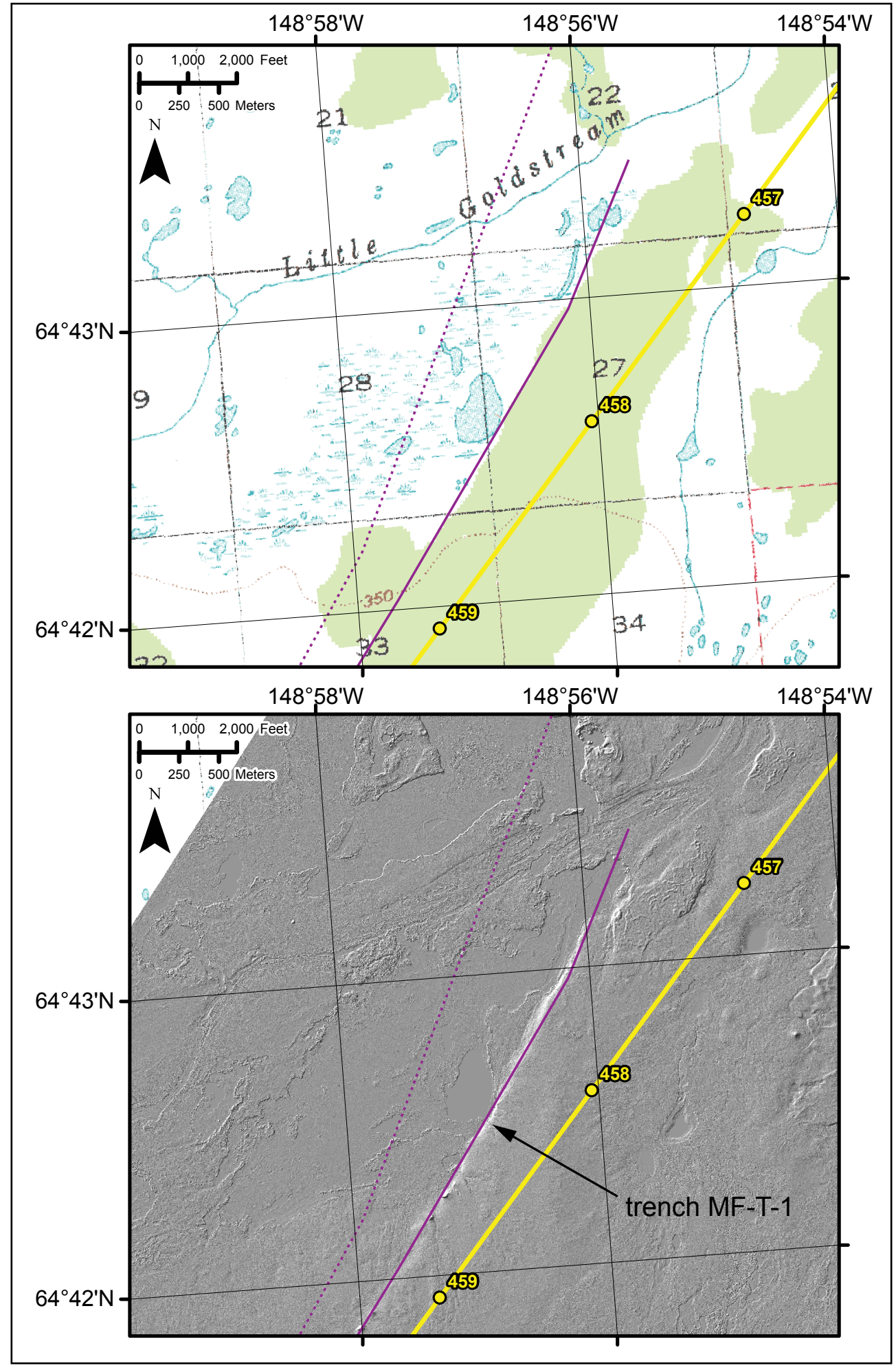

Figure 3. Topographic map (top) and lidar hillshade (bottom), showing previous mapping of the Minto fault (purple, solid and dotted) in the Minto Flats seismic zone. Proposed pipeline route shown in yellow. For reference, MP 458 is located at GPS coordinates $64.71^{\circ} \mathrm{N}, 148.934^{\circ} \mathrm{W}$. See Appendix A for references for previously mapped fault traces. 


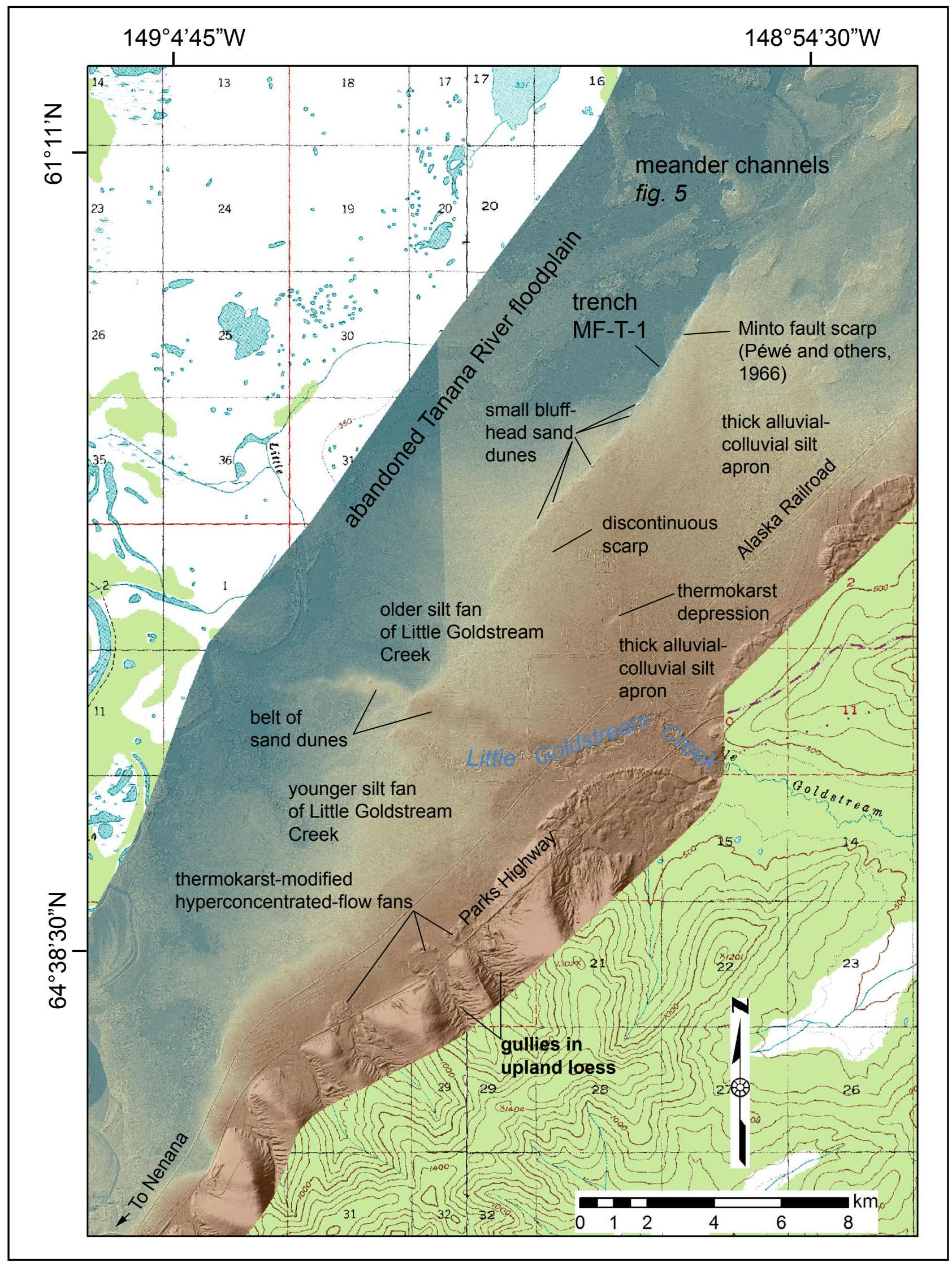

Figure 4. Geomorphic interpretation of lidar hillshade in the vicinity of the Minto fault. Small bluff-head sand dunes partially bury the scarp in places. The scarp has been cut off and scoured by fluvial processes associated with flooding on the Tanana River floodplain. A subtle scarp is present on a relatively older silt fan of Little Goldstream Creek. 


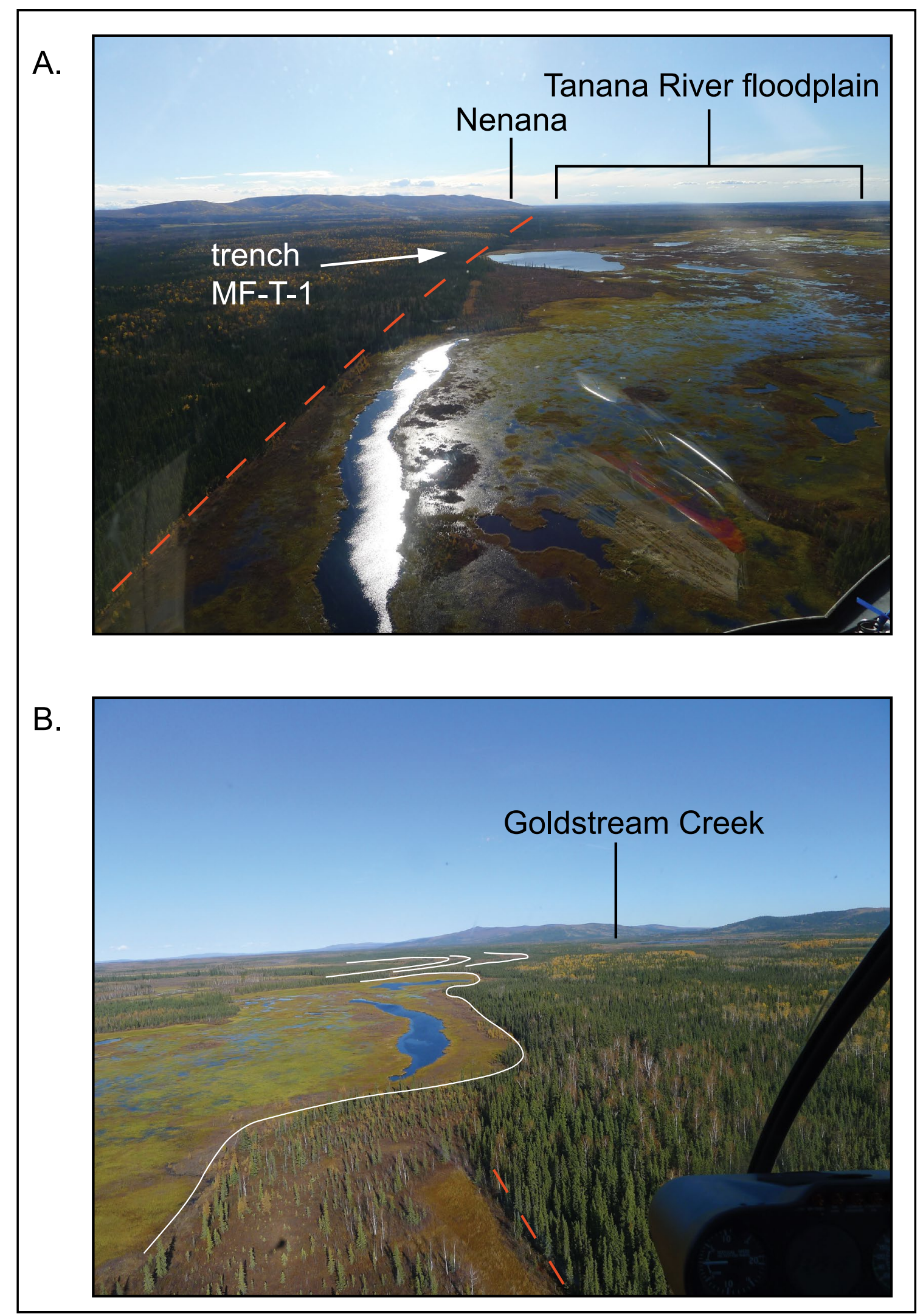

Figure 5. Photographs of fluvial geomorphology along the Minto fault. The mapped trace of the fault is shown in each photo by a dashed red line. A. View to south toward trench MF-T-1, taken from helicopter at GPS coordinates $64.722^{\circ} \mathrm{N}, 148.939^{\circ} \mathrm{W}$, showing the prominent floodplain of the Tanana River adjacent to the scarp. B. View to area north of the trench site, taken from helicopter at GPS coordinates $64.714^{\circ} \mathrm{N}$, $148.95^{\circ} \mathrm{W}$, showing prominent fluvial meander scars (white lines) that cut across the projection of the fault. 
satellite image showing that the eastern margin of the floodplain extends to the Minto fault. The modern Tanana River channel has straight reaches as long as or longer than the mapped extent of the Minto fault. We conclude that the Minto scarp is a fluvial terrace riser that was cut by floods of the Tanana River, and therefore is not a tectonic fault scarp.

We excavated a paleoseismic trench (MF-T-1) across the Minto fault south of the mouth of Goldstream Creek to evaluate the scarp's origin. The location of the trench is shown in figure 3, and photographs of the site and excavation are presented in figure 7. A stratigraphic log of the exposure is provided in figure 8. The trench was excavated from the top of the scarp to the flat surface of the abandoned Tanana River floodplain. The exposed stratigraphy consists of a basal frozen, silty, very-fine-grained sand (Unit 4) overlain and interfingering with a thin, dark gray-brown silt (Unit 3). Unit 3 is overlain by silt to very-fine-grained sand that is thinly $(1-3 \mathrm{~cm}$ ) bedded (Unit 2). Unit 2 gradually transitions upward to Unit 1, a massive tan-brown silt interpreted to be eolian loess. Units 2 and 4 dip gently to the northwest and are interpreted to be fluvial overbank deposits sourced from the Tanana River. Unit 3 contains burned charcoal fragments and is interpreted to be a buried soil that developed during a hiatus in overbank deposition. Radiometric analyses on Salicaceae and unidentified hardwood charcoal fragments within Unit 3 indicate that the soil was exposed at the surface around 11,710 to $12,030 \mathrm{cal}$ yr. B.P. (see fig. 8 and Appendix B, sample RDK-MF-1). No obvious faults were observed in the exposure, and the buried soil extends unbroken across the entire exposure.

The observations are consistent with an erosional origin for the scarp as inferred by Page and others (1995), from which we conclude that the Minto fault has not generated surface fault ruptures in the vicinity of the proposed pipeline route in the

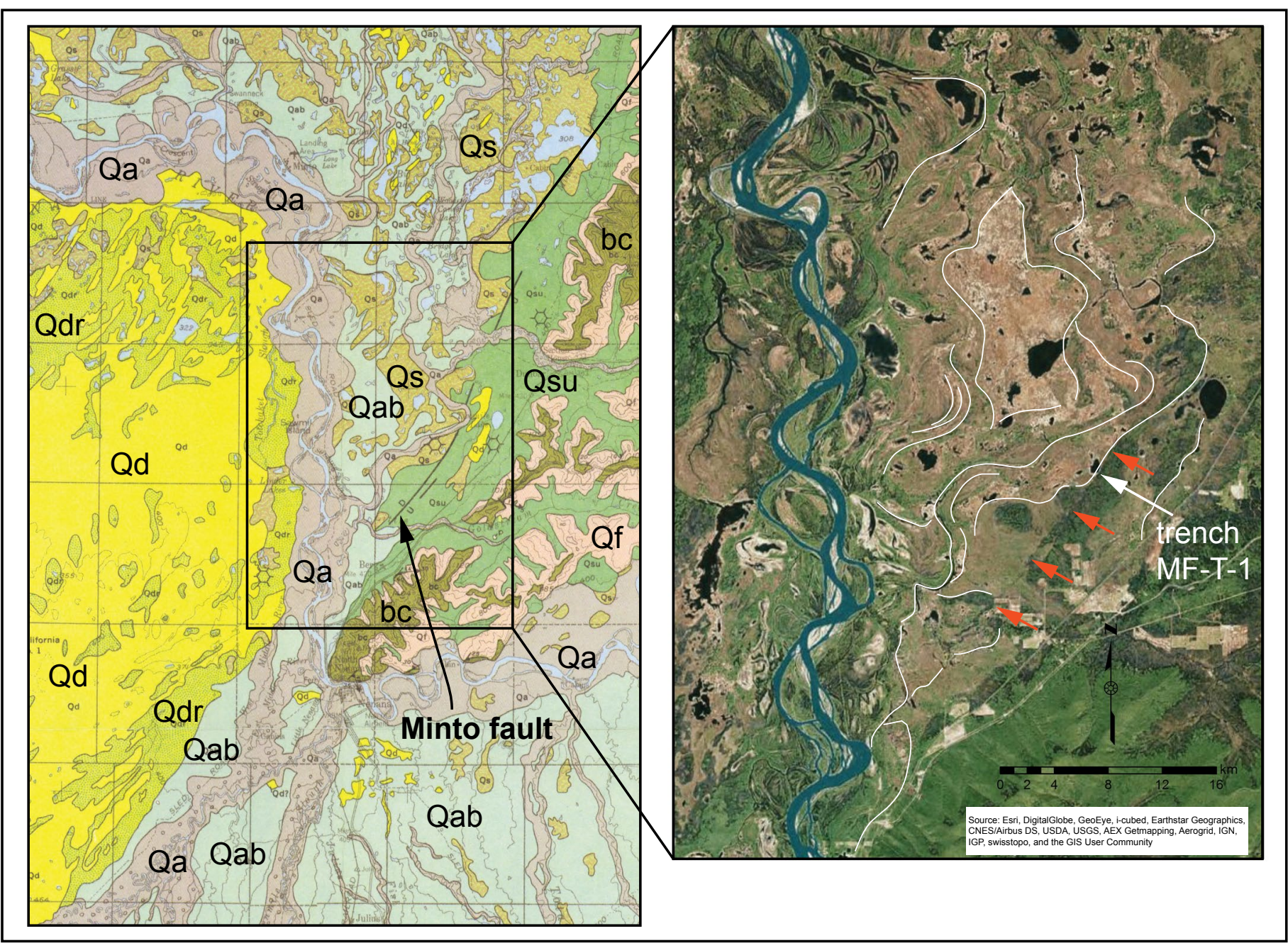

Figure 6. Previous mapping (left) of the Tanana River floodplain and Minto fault (Péwé and others, 1966) and satellite image (right), showing prominent meander channel margins (white lines) in the vicinity of the Minto fault (red arrows). Not all meander channels are depicted. Unit abbreviations from Péwé and others (1966) include: $b c=$ Birch Creek Schist; Qsu = perennially frozen silt; $Q$ s = swamp deposits; $Q d$ = dune sand; $Q \mathbf{a b}=$ abandoned floodplain alluvium; $Q \mathbf{a}=$ floodplain alluvium; $Q d r$ = dune sand reworked; Qf = upland silt (Fairbanks loess). 


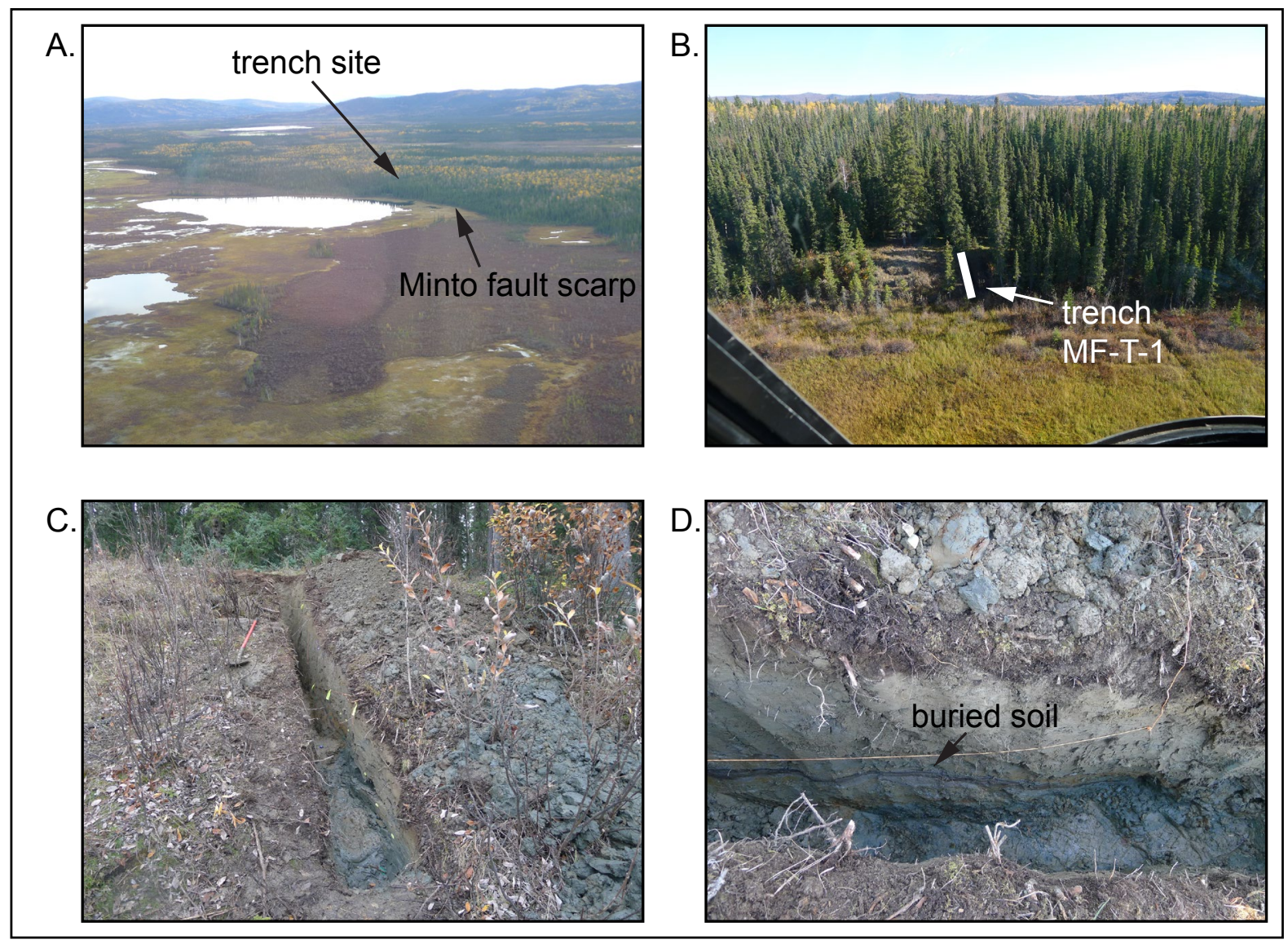

Figure 7. Photographs of the Minto fault trench at GPS coordinates $64.709^{\circ} \mathrm{N}, 148.947^{\circ} \mathrm{W}$. A. Overview of the site. B. Close-up view of the scarp; trench is obscured by tree shadow and indicated by white rectangle. C. Ground view of trench excavation. D. Undeformed soil near base of trench exposure; trench was hand-excavated September 9, 2014. No faults were observed in the trench exposure, and the buried soil extends unbroken across the entire exposure.

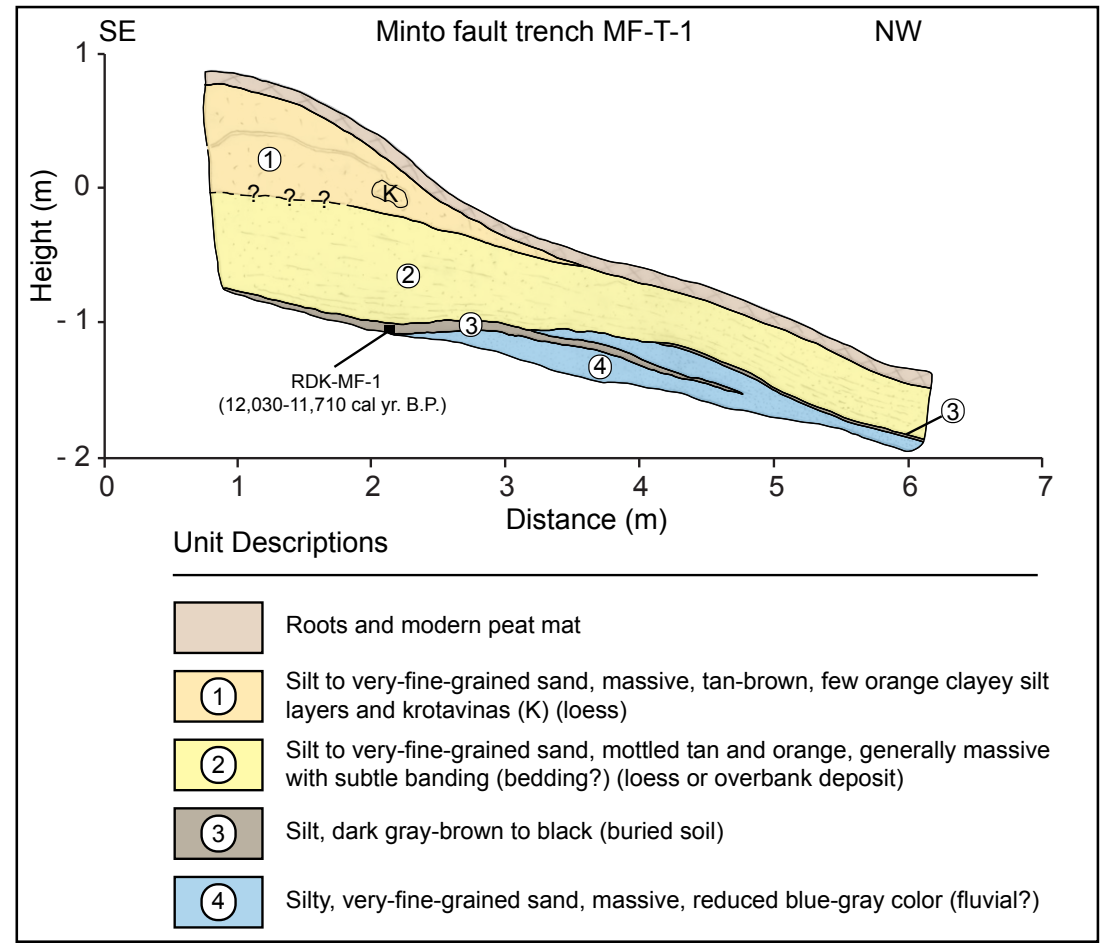

Figure 8. Stratigraphic log of trench MF-T-1 excavated across the Minto fault. $\mathrm{K}=$ krotavina. 
Holocene Epoch. Although the Minto Flats seismic zone is capable of producing frequent moderate-magnitude earthquakes, no geomorphological evidence has been found to indicate that these events can be associated with surface rupture. Thus we eliminate the Minto fault from consideration.

\subsection{Northern Foothills Fold and Thrust Belt}

The Northern Foothills Fold and Thrust Belt (NFFTB) is a system of imbricate thrust faults that extends more than $500 \mathrm{~km}$ along the northern flank of the Alaska Range and accommodates a component of north-directed compression north of the Denali fault. The system has been subdivided into the eastern, western, and Kantishna Hills sections based on differences in structural style (Bemis and others, 2012). The proposed pipeline extends across the western part of the system (fig. 9) where diffuse seismicity is associated with several faults including the Park Road, Healy, Healy Creek, and Stampede-Little Panguingue Creek faults and the Northern Foothills thrust and associated backthrusts, described separately below.

Evidence for long-term active deformation across the NFFTB includes variably dipping beds of Tertiary Usibelli Group rocks exposed in the cliffs along the Nenana River and uplifted and warped Plio-Pleistocene Nenana Gravel and glacial deposits that form a series of east-west-trending anticlines and synclines (fig. 10) (Péwé and others, 1966; Wahrhaftig, 1958; Bemis, 2004, 2010). Maximum horizontal shortening across the western part of the system has been estimated at $\sim 3 \mathrm{~mm} / \mathrm{yr}$ (Bemis and Wallace, 2007). Despite widespread topographic and structural evidence of active deformation, few paleoseismic studies have been conducted along the NFFTB, and information on slip rates and displacement parameters is limited.

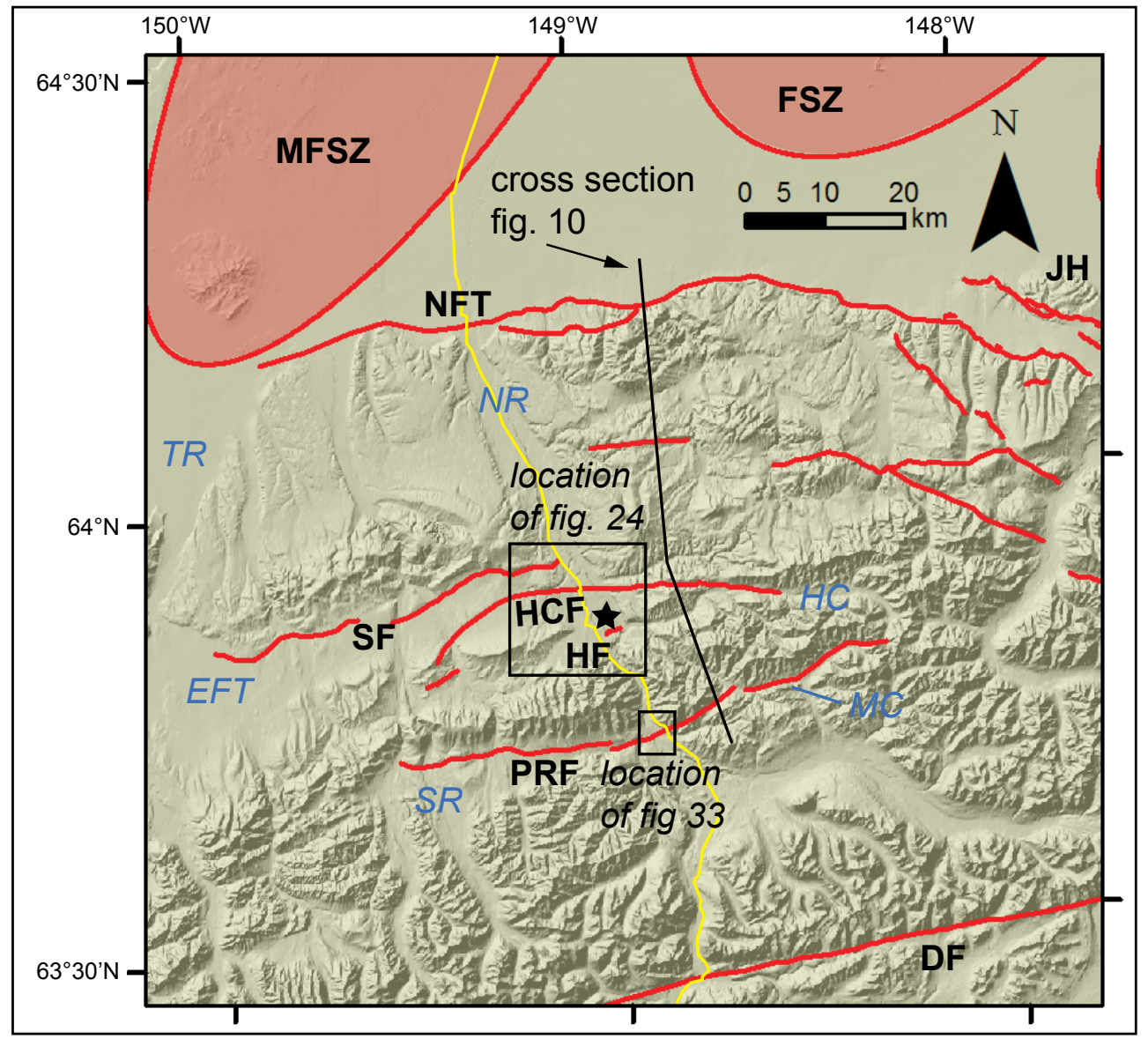

Figure 9. Hillshade map of part of the western section of the Northern Foothills Fold and Thrust Belt, showing active faults (bold red lines) and seismic zones (shaded red) of the Quaternary fault and fold database (Koehler and others, 2012a). Proposed pipeline route shown in yellow. PRF = Park Road fault; $\mathrm{HF}=$ Healy fault; $\mathrm{HCF}=$ Healy Creek fault; $\mathrm{SF}=$ Stampede fault; NFT = Northern Foothills thrust; DF = Denali fault; MFSZ = Minto Flats seismic zone; FSZ = Fairbanks seismic zone; $\mathrm{SR}=$ Sanctuary River; $\mathrm{MC}=$ Moody Creek; EFT = East Fork Toklat River; $\mathrm{HC}=$ Healy Creek; $\mathrm{TR}=$ Toklat River; NR = Nenana River; JH = Japan Hills. The town of Healy (black star) is located at GPS coordinates $63.862^{\circ} \mathrm{N}, 149.006^{\circ} \mathrm{W}$. 


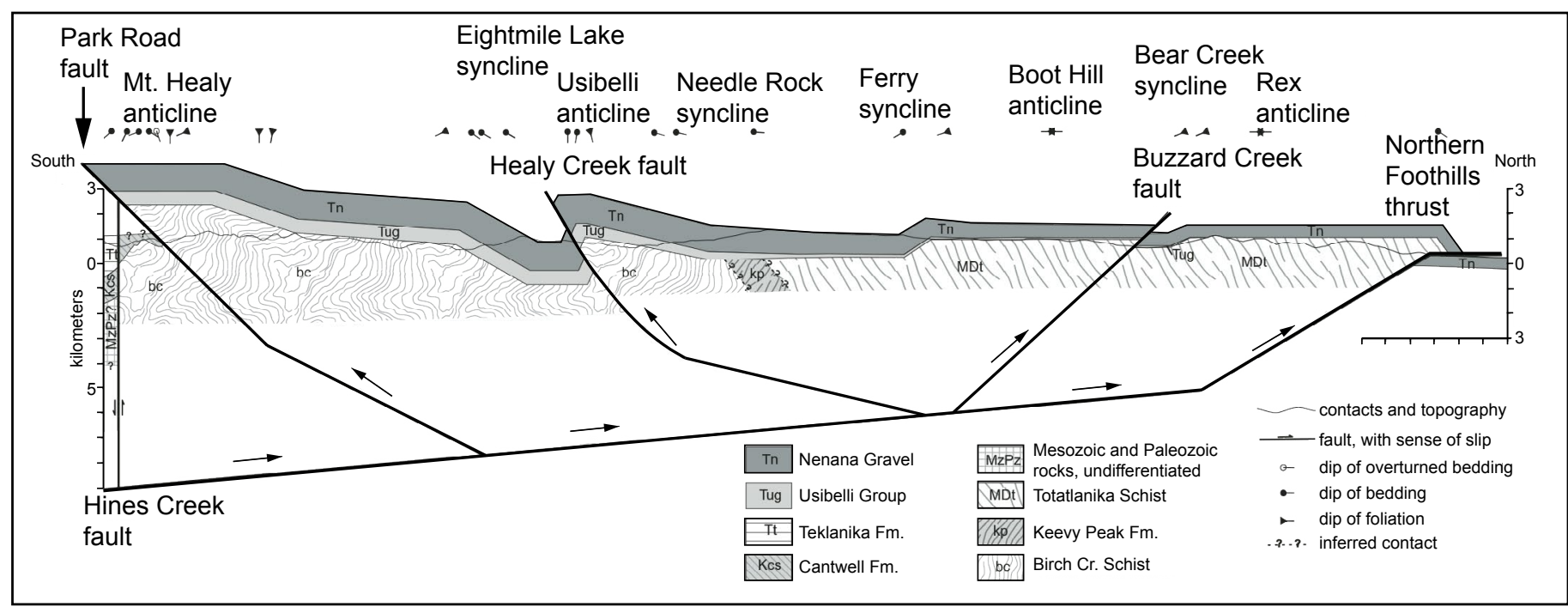

Figure 10. Cross section, Northern Foothills Fold and Thrust Belt, modified from Bemis and Wallace (2007). Approximate location of section shown on figure 9.

The main frontal fault of the system, the Northern Foothills thrust fault, is thought to be the source of the $1947 \mathrm{M}_{\mathrm{b}} 7.2$ earthquake (Wickens and Hodgson, 1967). Although surface rupture was not documented, this earthquake underscores the possibility of future magnitude 6-7 earthquakes in the thrust belt. Based on uncertainties in potential future rupture lengths we do not report empirically-based estimates of maximum magnitude for faults of the Northern Foothills Fold and Thrust Belt.

\subsubsection{Northern Foothills Thrust}

The 150-km-long, active, Northern Foothills thrust is the master basal detachment of the NFFTB and is responsible for uplift and deformation of the northern foothills of the Alaska Range (fig. 10). The fault dips 30-45 degrees to the south (Bemis and Wallace, 2007) and is mapped from the Toklat River in the west to the vicinity of the Delta River in the east (fig. 9) (Bemis and others, 2012). Active folding in the hanging wall of the fault has resulted in the development of a large monocline in Tertiary Nenana Gravel (recognized by Péwé and others, 1966) and uplift and preservation of terraces associated with the undated middle Pleistocene Browne glaciation at the mouth of the Nenana River canyon (Bemis and others, 2012; Bemis, 2010). Late Pleistocene activity has been documented along the fault at sites near the Nenana and Wood rivers, based on mapping of offset fluvial terraces (Bemis, 2010); however, no Holocene offsets have been documented previously. In the vicinity of Windy Creek, shallow trench excavations provide evidence that the most recent surface-rupturing earthquake along the Northern Foothills thrust occurred before 26,591-25,751 cal yr BP (Bemis, 2010). The mapped trace of the fault crosses the proposed pipeline alignment at MP 496.33 at a strike of 268 degrees; however, the location of the fault is poorly constrained (fig. 11).

We performed helicopter reconnaissance along the fault from the Japan Hills to the Toklat River and conducted limited ground surveys of an offset alluvial fan approximately $19 \mathrm{~km}$ east of the Nenana River. Additionally, we inspected lidar hillshade images and constructed profiles across the mapped trace of the fault in the vicinity of the proposed pipeline route. West of the Nenana River our helicopter observations indicate that the trace of the fault along the front of the north-facing Nenana Gravel monocline extends across torrential fan deposits, frozen loess, and sand dunes and is obscured by heavy vegetation, limiting our ability to map its location. From the Nenana River to the Japan Hills, the fault is characterized by multiple splays distributed over several kilometers north of the range front. The range front is oversteepened at the base, but commonly obscured by thick vegetation (fig. 12A). Large scarps in undated alluvial-fan deposits are more than $20 \mathrm{~m}$ high and have a beveled morphology with youthful basal facets several meters high. Between Windy Creek and Tatlanika Creek multiple discontinuous youthful scarps offset alluvial fans and slope colluvium (figs. 12B and C). Approximately $10 \mathrm{~km}$ east of Windy Creek we visited a scarp that cuts a late Pleistocene/Holocene alluvial fan (fig. 13). There the scarp is $\sim 3 \mathrm{~m}$ high and beveled with an oversteepened base $(\sim 1 \mathrm{~m})$. Although the scarp morphology suggests the occurrence of more than one paleoearthquake, the age of the most recent earthquake is indeterminate.

Inspection of the lidar hillshade images indicates that the proposed pipeline route traverses an undated fluvial terrace that is smooth and relatively flat. We found no evidence of obvious scarps along the mapped trace of the Northern Foothills thrust 


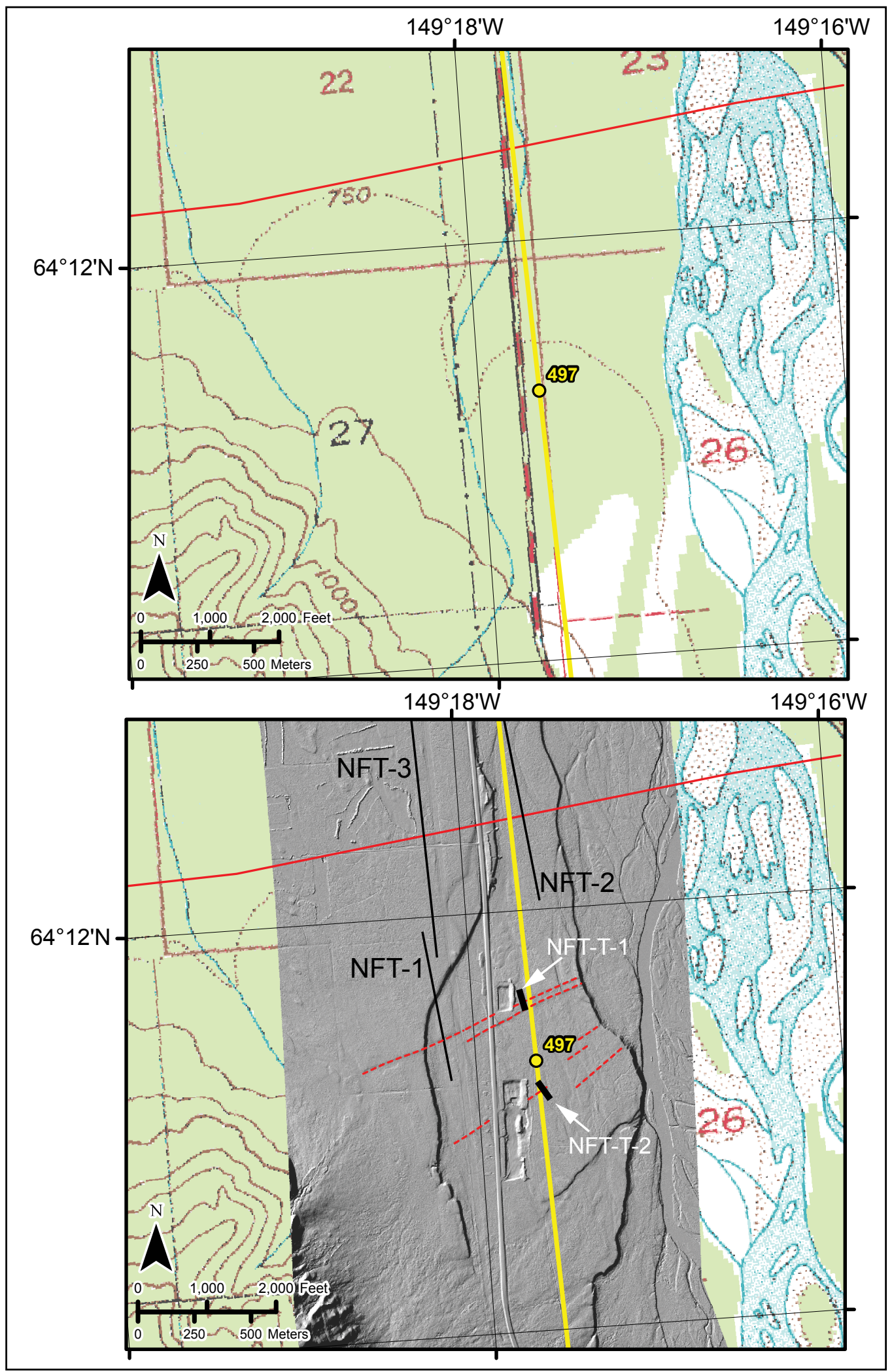

Figure 11. Topographic map (top) and lidar hillshade (bottom), showing previous fault mapping of the Northern Foothills thrust (solid red line; Koehler and others, 2012a) and mapping of associated backthrust faults (dashed red lines, this study) south of the main trace in the vicinity of the proposed pipeline crossing. Proposed pipeline route shown in yellow; black lines identify locations of profiles shown in figure 14. Thick black bars and white labels show locations of the Northern Foothills backthrust trenches. For reference, MP 497 is located at GPS coordinates $64.194^{\circ} \mathrm{N}, 149.295^{\circ} \mathrm{W}$. 


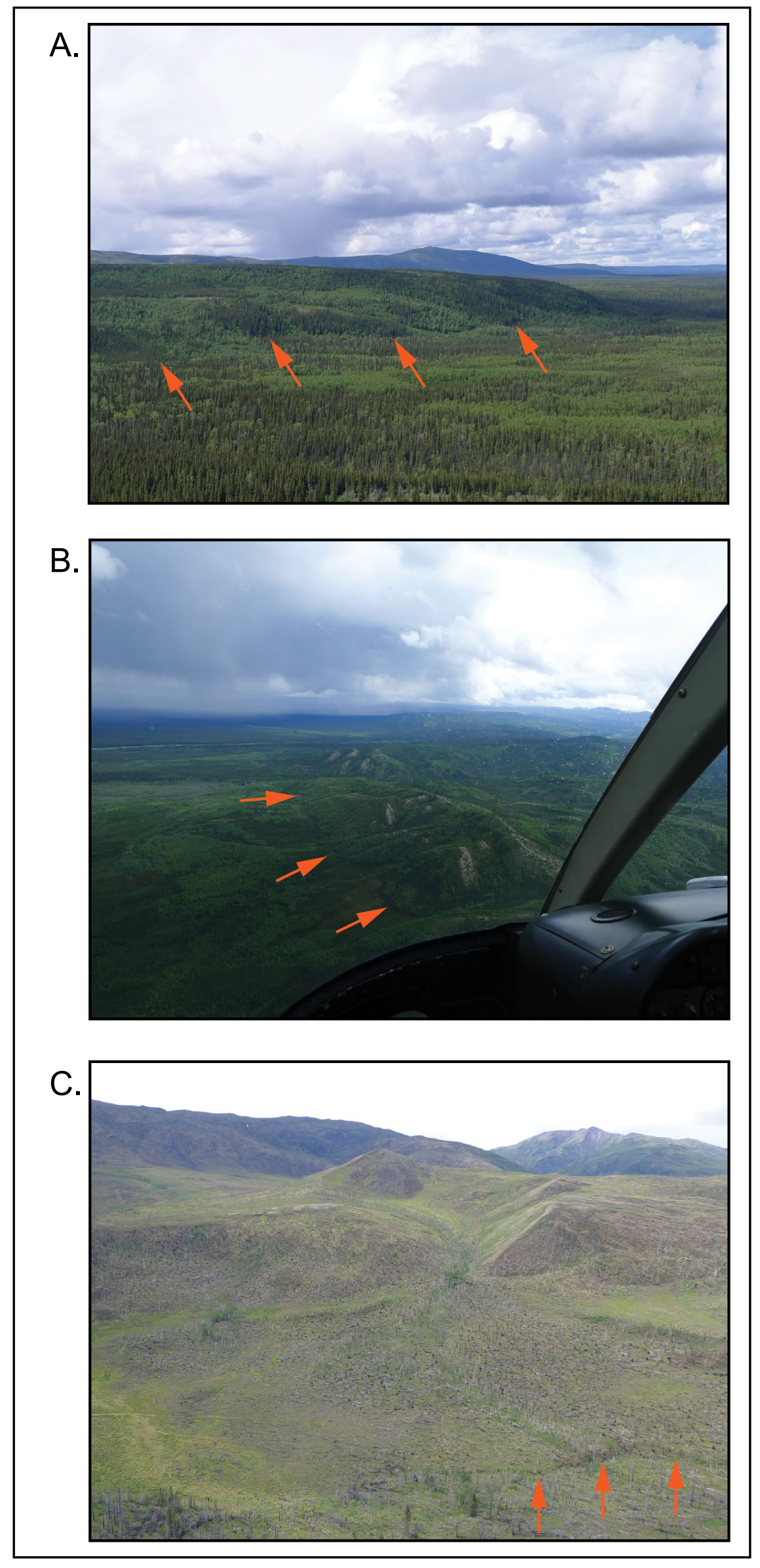

Figure 12. Photographs of the Northern Foothills thrust east of the Nenana River. Red arrows point to fault scarps in all photos. A. View to west of the range front, showing oversteepened scarp and thick forest cover. Photograph taken from helicopter from approximate GPS coordinates $64.222^{\circ} \mathrm{N}, 148.946^{\circ} \mathrm{W}$. B. View to east of the Totatlanika River, showing discontinuous, youthful scarps in slope colluvium. Photograph taken from helicopter from approximate GPS coordinates $64.223^{\circ} \mathrm{N}, 148.752^{\circ} \mathrm{W}$. C. View to south of youthful scarp in an alluvial fan. Photograph taken from helicopter from GPs coordinates $64.221^{\circ} \mathrm{N}, 148.926^{\circ} \mathrm{W}$. 


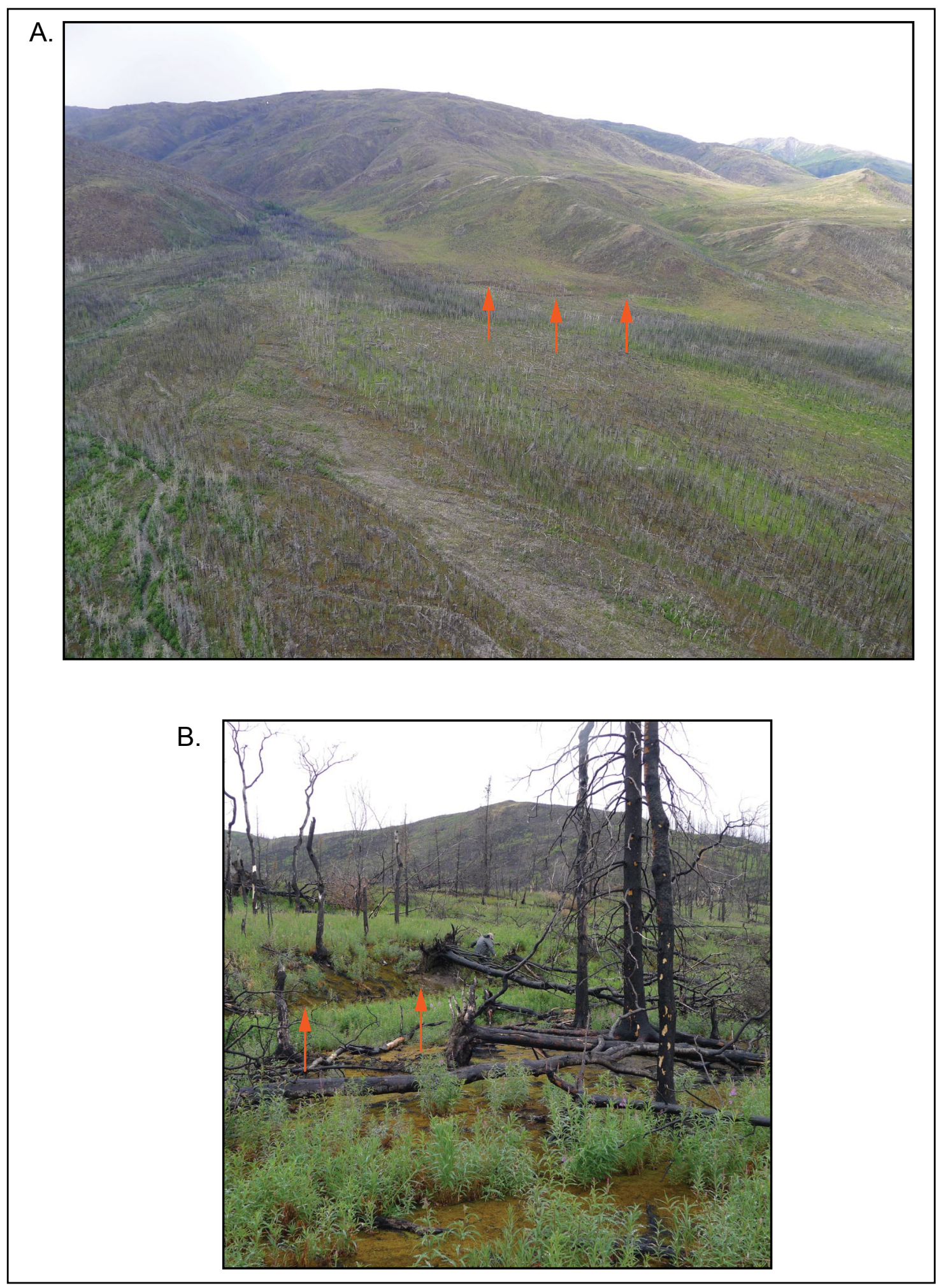

Figure 13. Photographs of the Northern Foothills thrust; red arrows point to the scarp in both photos. A. Offset alluvial fan $\sim 10 \mathrm{~km}$ east of Windy Creek. B. Close-up view of the scarp; geologist for scale. GPS coordinates $64.208^{\circ} \mathrm{N}, 148.876^{\circ} \mathrm{W}$. 
in the vicinity of the pipeline route. Figure 14 shows topographic profiles across the mapped trace of the fault adjacent and parallel to the proposed pipeline crossing. Profile NFT-3 extends across a fluvial terrace mapped as Riley Creek-aged outwash (Péwé and others, 1966) and Profile NFT-2 extends across an inset, undated fluvial terrace. Both profiles indicate that the terrace surfaces gently slope to the north and are not offset across the fault. A subtle rise of $\sim 0.5 \mathrm{~m}$ approximately $150 \mathrm{~m}$ south of the mapped trace of the fault on Profile NFT-2 could indicate the location of the fault; however, this is unlikely based on the lack of a similar feature on the older Riley Creek-aged surface (Profile NFT-3).

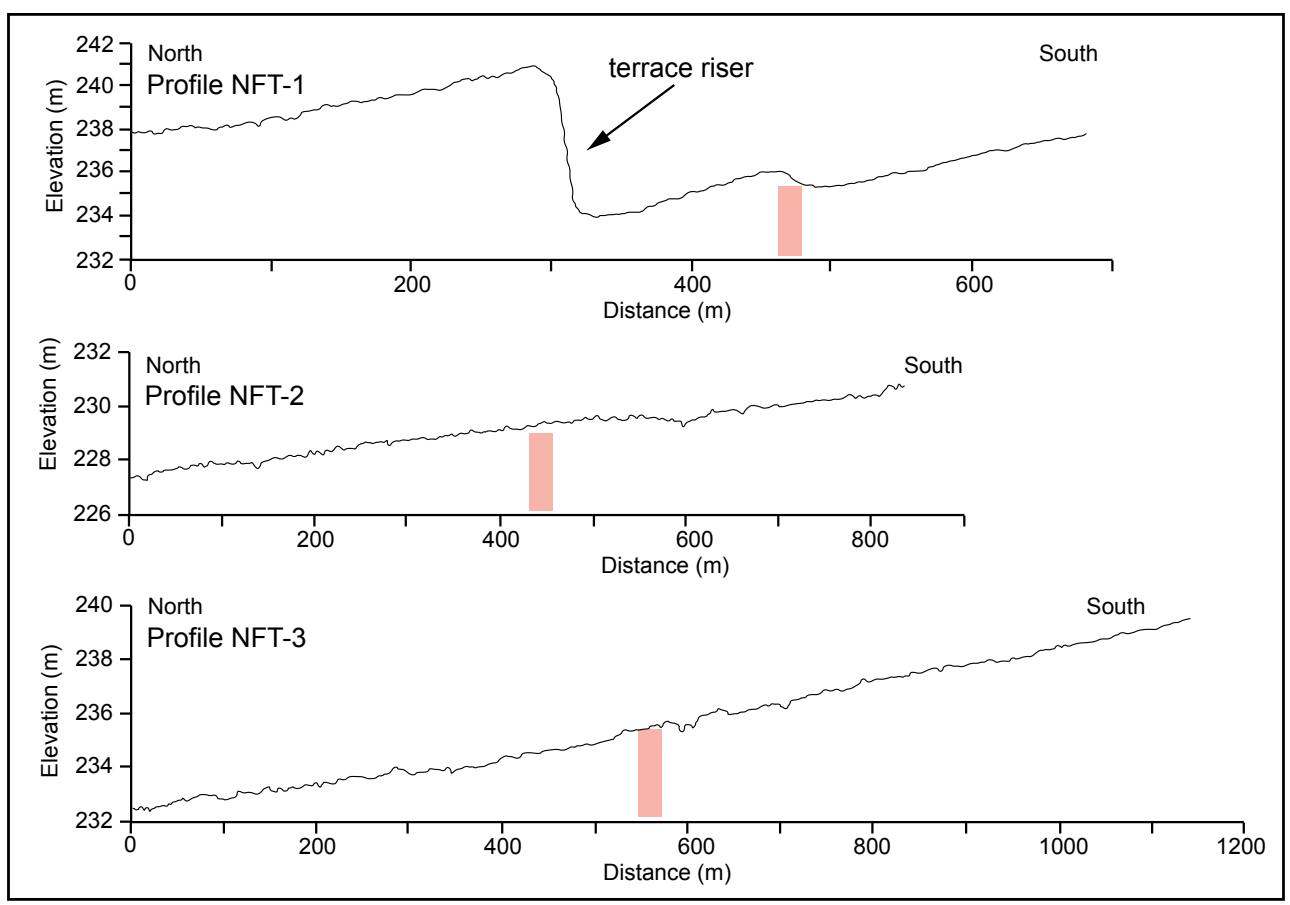

Figure 14. Topographic profiles across the mapped trace of the Northern Foothills thrust (profiles NFT-2 and NFT-3) and an active backthrust south of the main fault (profile NFT-1). Locations of faults shown by shaded rectangles. Profile locations shown on figure 11.

Although Holocene deposits do not appear to be offset along the fault at the proposed pipeline crossing, the potential for future surface-rupturing earthquakes along the fault remains uncertain. Offset fluvial terraces and alluvial fans, discontinuous scarps in slope deposits north of the main range front monoclinal escarpment, and the fault's role as the major detachment of the active NFFTB together indicate that the fault is likely an active fault. We recommend additional field studies to better locate the fault and better characterize fault-rupture parameters. We recommend that lidar data be acquired along the Northern Foothills thrust for approximately $20 \mathrm{~km}$ east and west of the mouth of the Nenana River canyon to assist in mapping the fault and assessing the ages and potential deformation of youthful deposits. If the evaluation of lidar data indicates plausible potential for Holocene surface ruptures, paleoseismic trenching may then be advisable as the next step in the confirmation process.

\subsubsection{Backthrusts Associated with the Northern Foothills Thrust}

During our assessment of lidar hillshade imagery from near the mouth of the Nenana River canyon we identified a zone of previously unrecognized lineaments south of the Northern Foothills thrust (fig. 11). The lineaments extend in orientations of 246-232 degrees across a Riley Creek-aged fluvial terrace and undated inset fluvial terraces of the Nenana River, the lowest of which is likely Holocene. The orientations of the lineaments are roughly perpendicular to abandoned braided channels on the terrace surfaces. The lineaments cross the proposed pipeline route between MP 496.75 and MP 497.18. We interpret the lineaments to be active backthrusts associated with the Northern Foothills thrust, and we conducted ground reconnaissance, topographic profile analyses, and paleoseismic trenching to verify the origin of the scarps as active tectonic structures.

Field observations indicate that the lineaments are characterized by small, south-facing scarps generally less than $1 \mathrm{~m}$ high. The lineaments are difficult to follow across the densely forested terrace surfaces; thus we relied on GPS-enabled 
lidar hillshade data on a field computer to guide our field traverses. The most prominent scarp is on the northern side of the zone near an abandoned gravel pit and can be followed continuously for about $1 \mathrm{~km}$ (figs. 11 and 15A). A topographic profile (NFT-1) constructed across the scarp west of the highway where it crosses a Riley Creek-aged outwash terrace shows that the scarp is about $1.5 \mathrm{~m}$ high, relatively steep, and likely related to a single event (see discussion of trenches below) (fig. 14). This scarp diminishes in height to the east to its crossing of the terrace riser to the Holocene terrace, where it is about $0.5 \mathrm{~m}$ high and offsets the riser and the floodplain terrace (figs. 15B and C). Lineaments along the southern side of the zone extend through an active gravel pit near the Parks Highway and extend discontinuously to the Holocene terrace to the east (figs. 11 and 15A). These lineaments are more difficult to follow and are generally less that $0.5 \mathrm{~m}$ high (fig. 15D). A reconnaissance study of the stratigraphy exposed in the wall of the southern gravel pit and a small excavation west of the highway by Devore and others (2012) indicate the presence of sheared gravels and deformation that occurred between $\sim 4,800$ and $\sim 1,800 \mathrm{yr}$ BP. Devore and others (2012) estimated the total cumulative surface offset across the entire zone of backthrusts, including the Northern Foothills thrust, was $5.5 \mathrm{~m}$ distributed across a $2.5 \mathrm{~km}$ zone. It is unknown how this deformation is partitioned between a broad warp across the entire zone and discreet faults. However, the surface geomorphology suggests that individual offsets across the backthrusts are small, on the order of a meter or less.
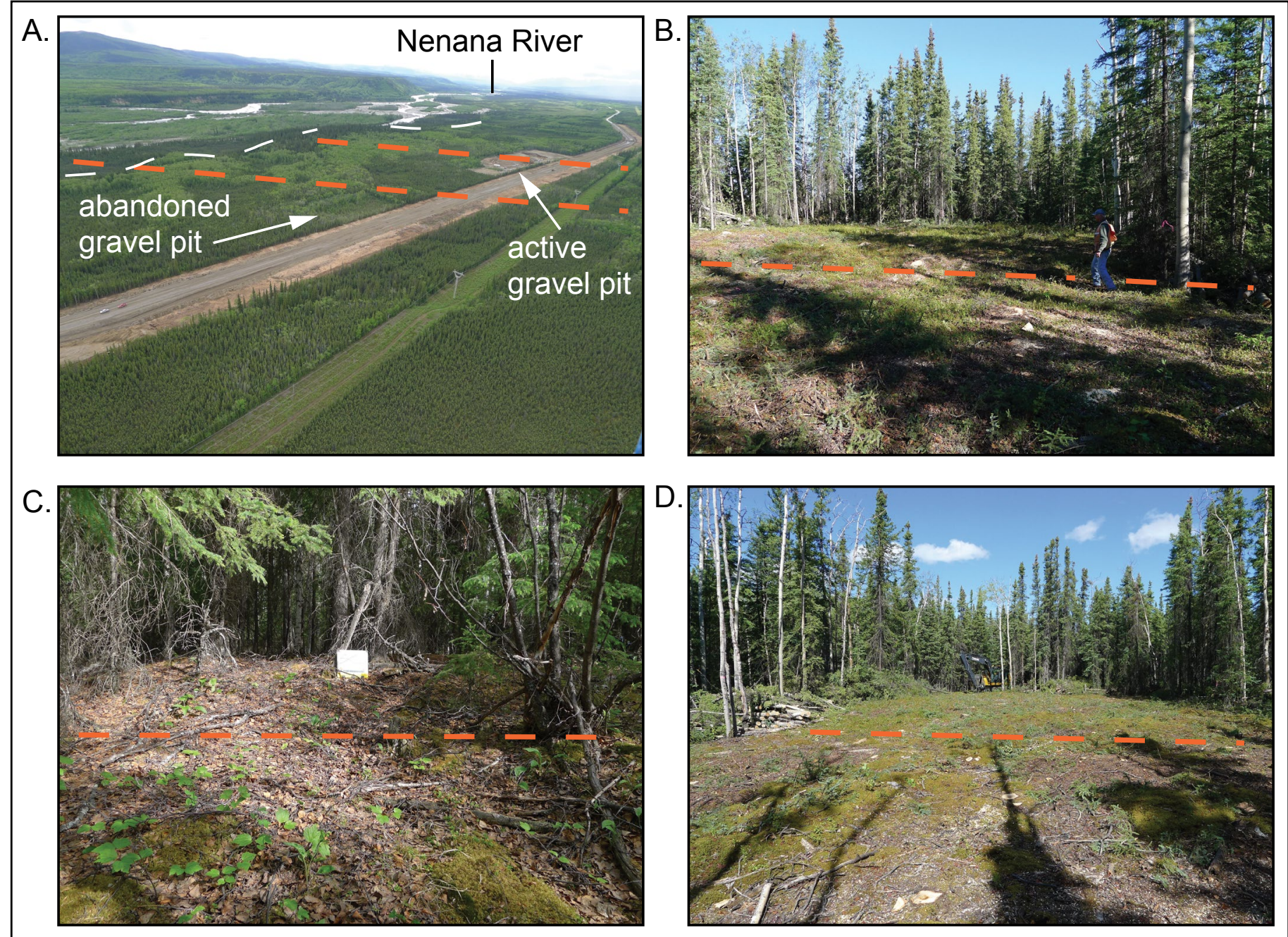

Figure 15. Photographs of backthrusts associated with the Northern Foothills thrust; approximate locations of the backthrusts shown by dashed red lines. A. View to the southeast of terrace surfaces traversed by scarps, showing abandoned and active gravel pits referred to in text. White dashed line shows terrace riser between Riley-aged outwash terrace and Holocene terrace. Photograph taken from helicopter at GPS coordinates $64.199^{\circ} \mathrm{N}, 149.299^{\circ} \mathrm{W}$. B. View to the north of the northernmost scarp and location of trench NFT-T-1. Geologist at base of scarp for scale. GPS coordinates $64.196^{\circ} \mathrm{N}, 149.296^{\circ} \mathrm{W}$. C. View to the north of small scarp on Holocene terrace. Map board (for scale) is about $12^{\prime \prime}$. GPS coordinates $64.197^{\circ} \mathrm{N}, 149.291^{\circ} \mathrm{W}$. D. View to the north of scarp that extends through the active gravel pit and site of trench NFT-T-2. GPS coordinates $64.193^{\circ} \mathrm{N}, 149.294^{\circ} \mathrm{W}$. Backhoe for scale. 
Trenches NFT-T-1 and NFT-T-2 were excavated across the prominent northern and southern lineaments, respectively, adjacent to the proposed pipeline route. The locations of the trenches are shown on figure 11, and stratigraphic logs of the exposures are shown in figures 16 and 17. The topographic scarp at each trench is between 0.4 and $0.7 \mathrm{~m}$ high, and likely related to single event displacement (see discussion below). Both trenches exposed a massive- to crudely-bedded fluvial pebble gravel deposit (Unit 3) overlain by micaceous, very-fine- to fine-grained fluvial overbank sand deposits with coarse sand and pebble channel lenses (Unit 2). Eolian loess (Unit 1) overlies Unit 2 and consists of massive silt mixed and interbedded with very-fine-grained overbank sand at the downslope end of the scarp.

A fault exposed in both walls of trench NFT-T-1 cuts the fluvial gravels (Unit 3) and sand (Unit 2) but does not extend upward into Unit 1 (fig. 16). The fault dips north 45-50 degrees, flattens to 20-30 degrees toward the surface and is associated with aligned clasts and drag folding (fig. 18). Measured dip-slip displacement of the top of the fluvial gravels (Unit 3) is about $20 \mathrm{~cm}$ and is associated with about $40 \mathrm{~cm}$ of vertical uplift of the hanging wall. Bedding in the fluvial gravel (Unit 3), which dips south toward the fault zone, indicates that deformation was associated with development of a hanging wall anticline at least $10 \mathrm{~m}$ wide. The stratigraphic and structural relations indicate one late Pleistocene or Holocene earthquake occurred before deposition of Unit 1. Radiometric analyses on Picea charcoal fragments within Unit 1 (Samples NFT-T1-RDK1, NFT-T1-RDK3, NFT-T1-RDK4, and NFT-T1-RDK5, fig. 16, Appendix B) indicate that faulting occurred before $\sim 5,000$ cal yr. B.P.

Trench NFT-T-2 exposed stratigraphy identical to that of trench NFT-T-1 but did not contain an observable fault (fig. 17). At the southern end of the trench a distinct channel-fill deposit similar in composition to Unit 2 overlies the gravel. Although we included the channel deposit with Unit 2 based on composition, it clearly postdates deposition of the entire stratigraphic package. At this location the top of the fluvial pebble gravel is about $0.5 \mathrm{~m}$ lower than in the north end of the trench and coincides with the margin of the channel. To verify whether the channel eroded evidence of a fault, we logged the west wall of the trench between meter 20 and 25. On the west wall the fluvial sand deposit (Unit 2) is flat and undeformed, confirming the absence of a fault. Bedding in the pebble gravel (Unit 3) dips to the south beneath the scarp, from which we infer that tectonic deformation along this fault could be associated with folding in the hanging wall, but not surface rupture.

Although displacements are small, our trench results combined with our mapping, which shows that the northernmost fault extends to the east across a terrace likely Holocene in age adjacent to the Nenana River, indicate that the faults are active. We conclude that the lineaments are active backthrusts of the Northern Foothills thrust and speculate that they might move synchronously with the master thrust. 


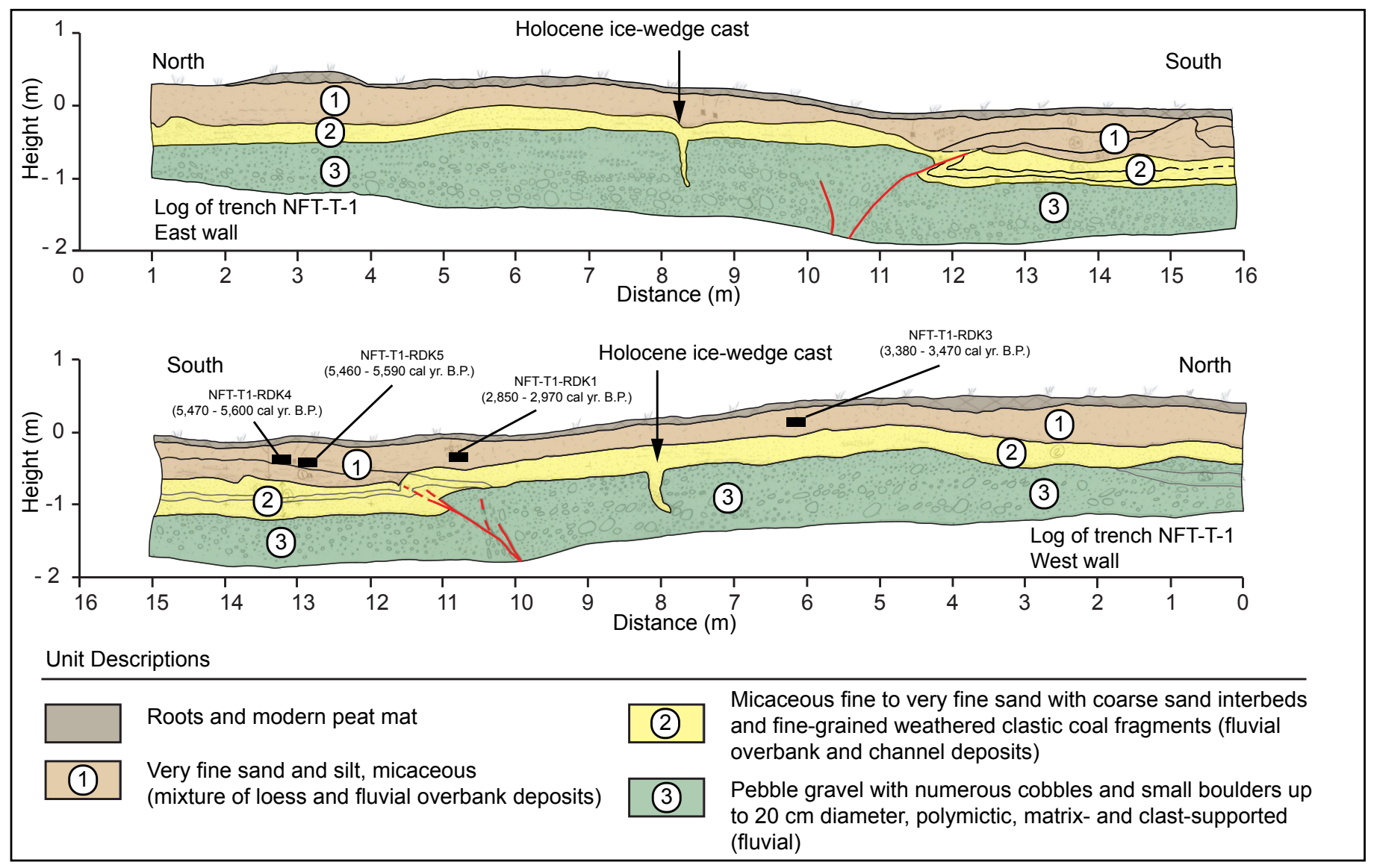

Figure 16. Stratigraphic log of the east and west walls of trench NFT-T-1.

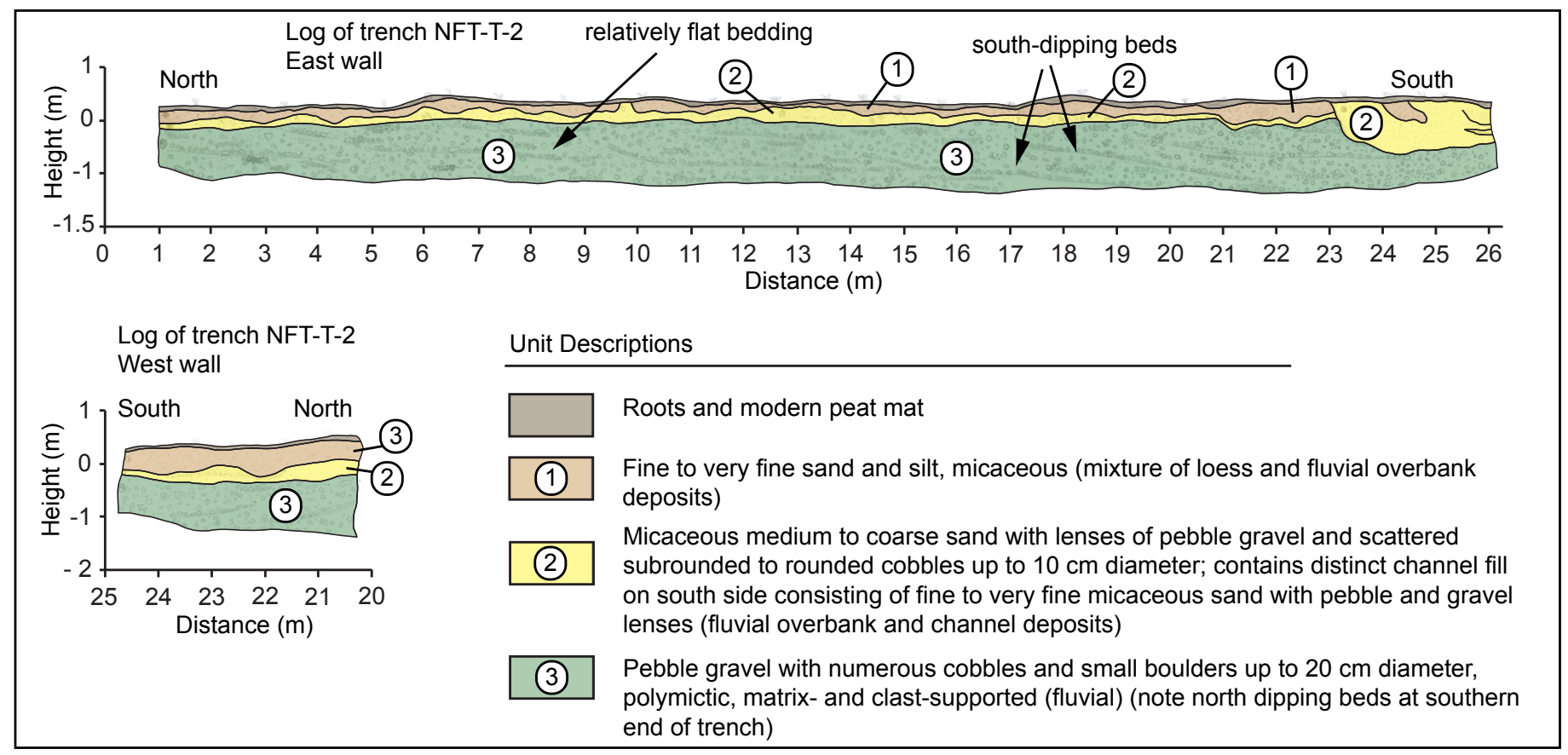

Figure 17. Stratigraphic log of the east and west walls of trench NFT-T-2. 


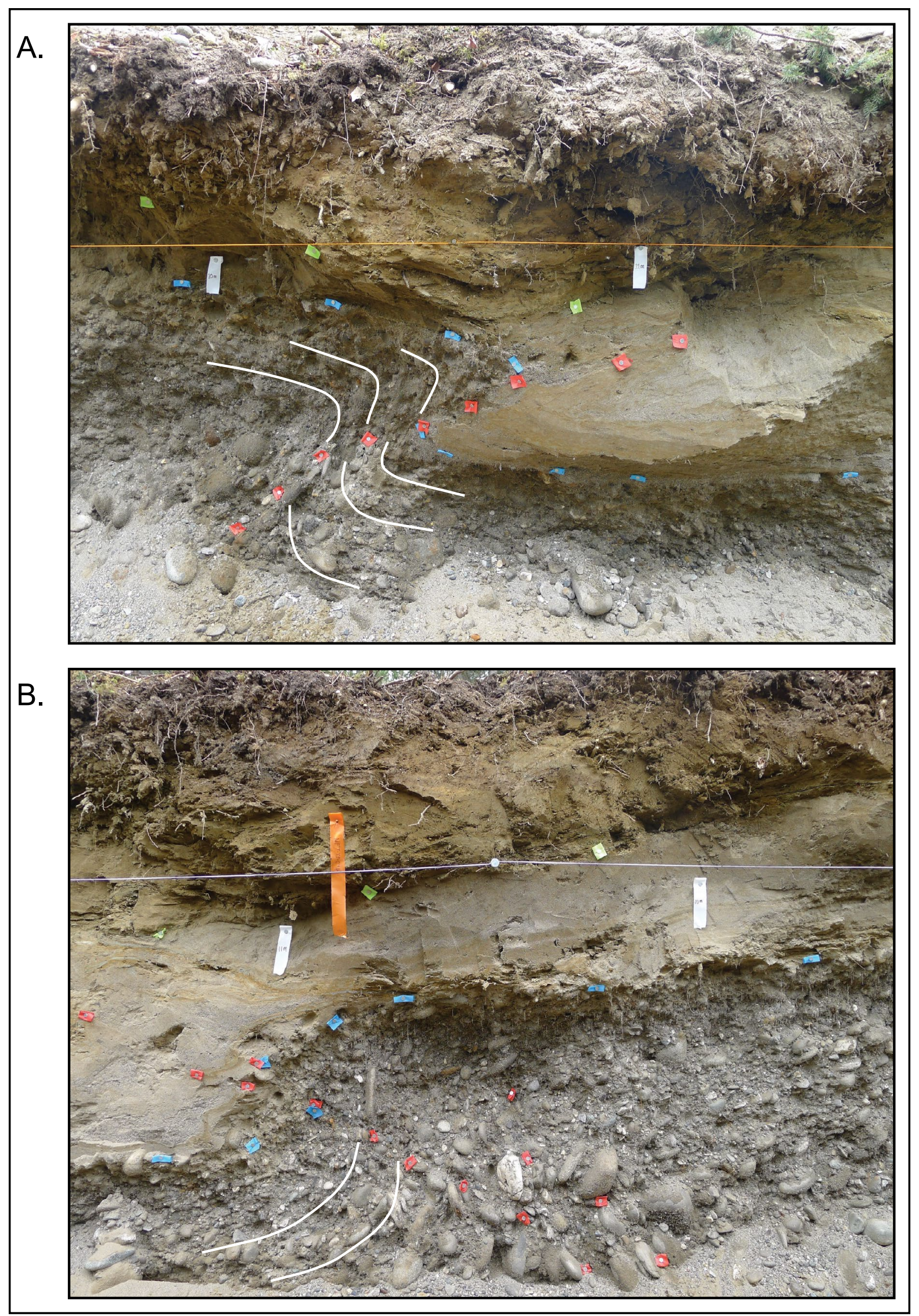

Figure 18. Photographs of fault exposed in Trench NFT-T-1. A. East wall. B. West wall. White lines show drag folding of the basal fluvial pebble gravel. 


\subsubsection{Stampede-Little Panguingue Creek Fault}

The potentially active Stampede-Little Panguingue Creek fault extends $45 \mathrm{~km}$ from the East Fork Toklat River on the west to the vicinity of the Parks Highway on the east (fig. 9). The fault is a thrust fault, inferred to dip $>60$ degrees north in the shallow subsurface and transitioning to a 15-30 degree dip at depth before merging with the underlying detachment of the Northern Foothills thrust (Bemis and others, 2012; Bemis and Wallace, 2007). Uplift of the hanging wall has resulted in deformation of the Tertiary Nenana Gravel and development of the Stampede anticline (Wahrhaftig, 1970b), indicating that it has been active in post Plio-Pleistocene time. The location of the intersection of the fault and pipeline route is not defined (fig. 19) and evidence of Quaternary activity is limited to antecedent drainages of the Savage, Teklanika, and Sushana rivers, which cut through the Stampede anticline and several uplifted surfaces in the vicinity of Savage River (fig. 20).

We conducted helicopter reconnaissance along the entire mapped trace of the fault and performed limited ground inspection of the fault near the Savage River. Along the southern flank of the Stampede anticline (figs. 20A and B) the fault is characterized by subdued tectonic geomorphology and lacks triangular facets, wineglass canyons, and other features typical of active faults. Undated glacial deposits (older than Lignite Creek Glaciation) are deposited against the base of the slope. At the confluence of the Teklanika and Savage rivers two surfaces are uplifted and preserved north of the fault (fig. 20C). The upper surface appears slightly warped (anticline?) and is tentatively correlated with the Nenana Gravel. The lower surface is relatively flat and inferred to be a glacial outwash terrace associated with an undated glacial advance, possibly Marine Isotope Stage (MIS) 8 or older. We did not observe any fault scarps in Holocene deposits between the Savage River and the Parks Highway.

We constructed topographic profiles where the fault projects toward the proposed pipeline alignment at two possible locations, MP 517.28 and MP 516.19 (fig. 21). Profile SF-1 is positioned across the distal end of an alluvial fan deposited on a fluvial terrace mapped as Riley Creek-aged outwash (Wahrhaftig, 1970b), where the mapped trace of the fault bends and projects toward the proposed pipeline route. The profile shows typical alluvial fan geomorphology, where the surface slopes gently to either side of the axial channel and the apex of the fan and is not deformed. Profile SF-2 is across the Riley Creek-aged terrace along a projection of the fault more consistent with the fault's regional orientation and shows a gently north-dipping slope that is also not deformed.

Based on these observations we conclude that the Stampede-Little Panguingue Creek fault has not displaced late Pleistocene or Holocene deposits where it projects toward the proposed pipeline route. Although the fault could become more active to the west, it does not evidence Holocene activity in the area investigated, and we eliminate it from further consideration. 


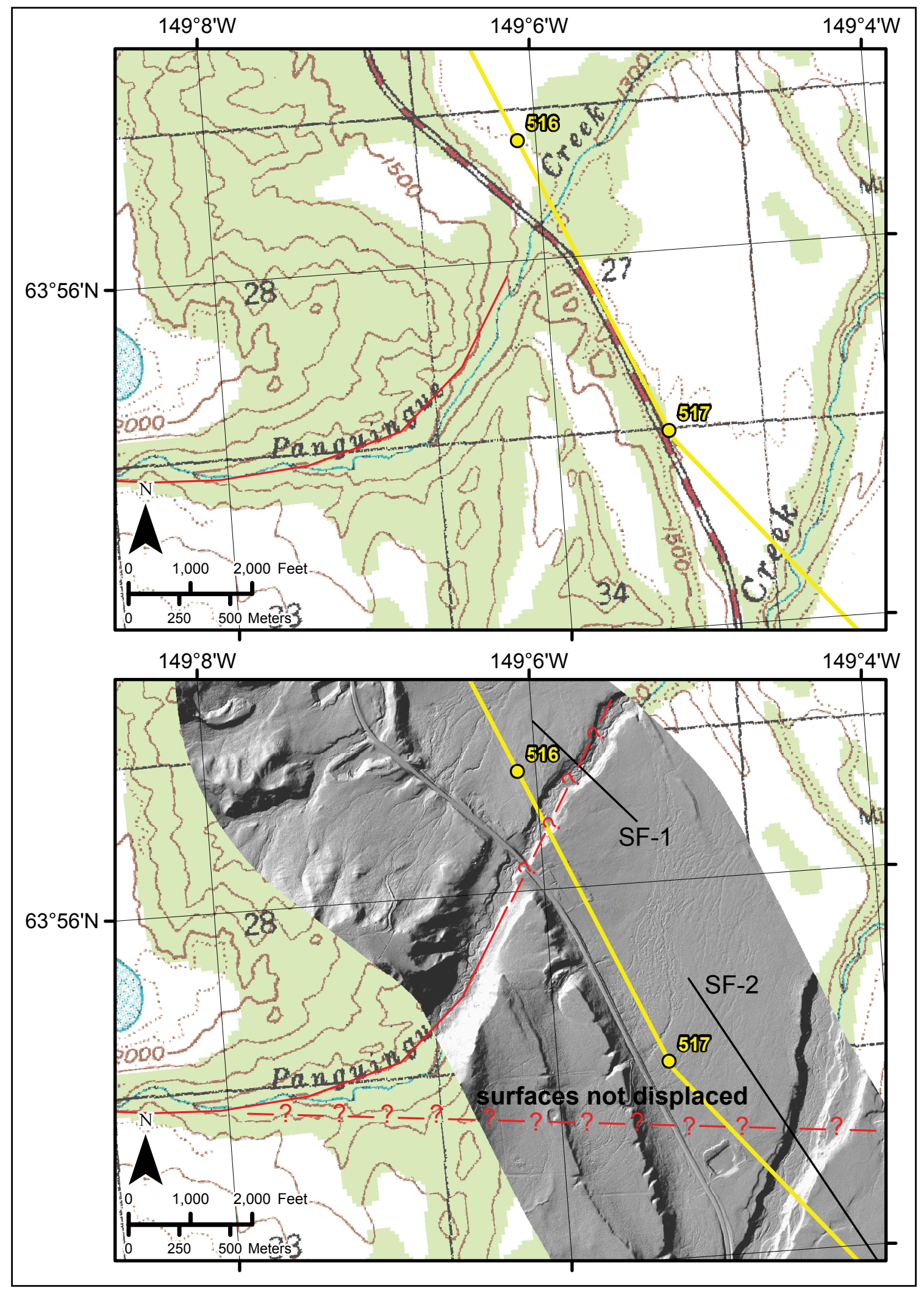

Figure 19. Topographic map (top) and lidar hillshade (bottom), showing previously-mapped trace of the Stampede-Little Panguingue Creek fault (solid red line, Koehler and others, 2012a) and projection of the mapped trace toward the proposed pipeline route (dashed and questioned red line, this study). Questioned red dashed lines show possible projections of the Stampede-Little Panguingue Creek fault trace toward the proposed pipeline route (this study). Note that surfaces along the projections are not displaced. Yellow line shows proposed pipeline route; black lines (SF-1 and SF-2) identify locations of topographic profiles shown in figure 21. For reference, MP 517 is located at GPS coordinates $63.925^{\circ} \mathrm{N}, 149.089^{\circ} \mathrm{W}$. 


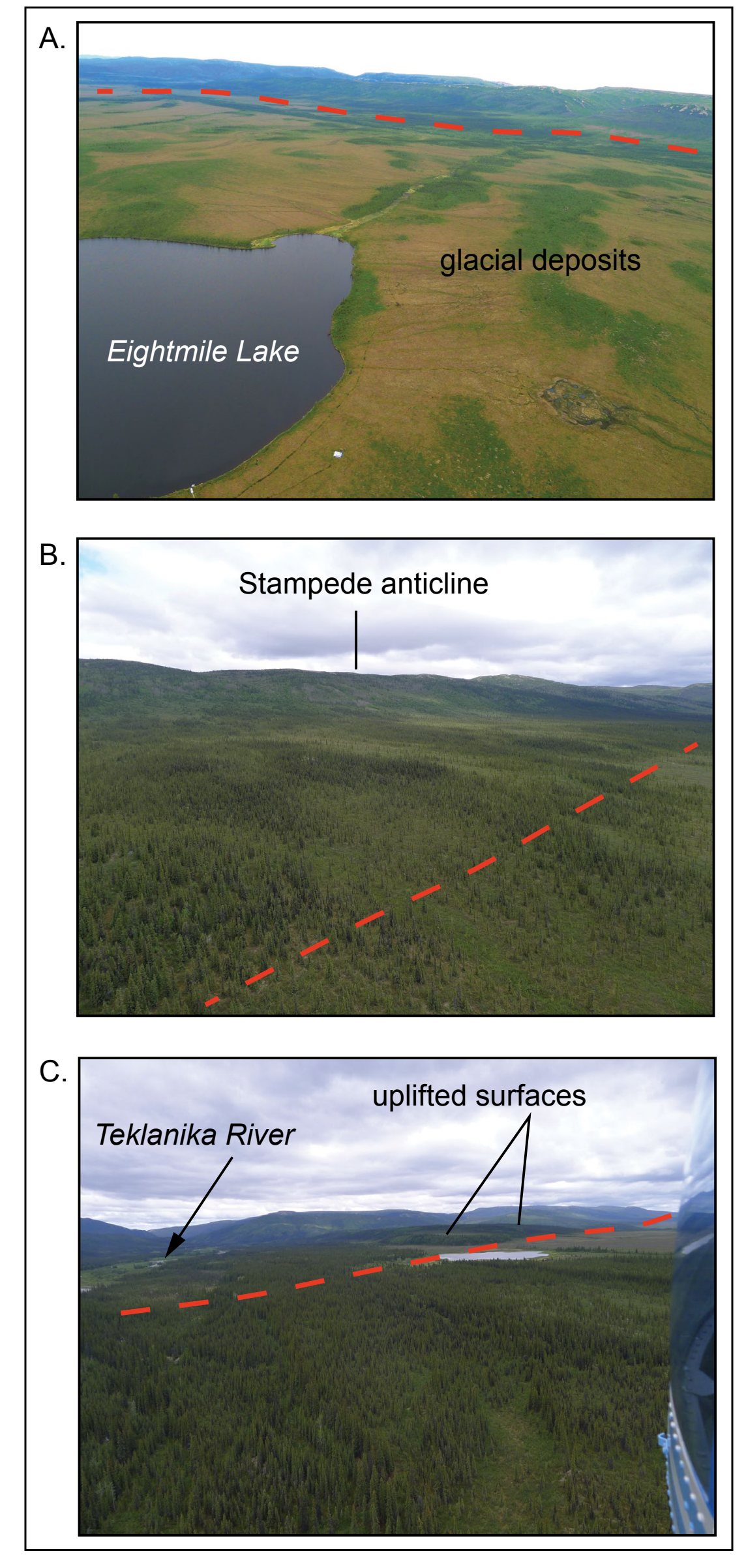

Figure 20. Helicopter photographs of the Stampede-Little Panguingue Creek fault; approximate location of fault is shown by a dashed red line in each photograph. Photos show a lack of prominent tectonic geomorphology along (A) the Stampede fault north of Eightmile Lake (photograph taken from GPS coordinates $63.889^{\circ} \mathrm{N}, 149.233^{\circ} \mathrm{W}$ ), and (B) east of the Savage River (photograph taken from approximate GPS coordinates $63.9^{\circ} \mathrm{N}$, $149.375^{\circ} \mathrm{W}$ ). C. Uplifted terrace surfaces along the Stampede fault at the confluence of the Savage and Teklanika rivers. View to the northeast from GPS coordinates $63.868^{\circ} \mathrm{N}, 149.505^{\circ} \mathrm{W}$. 


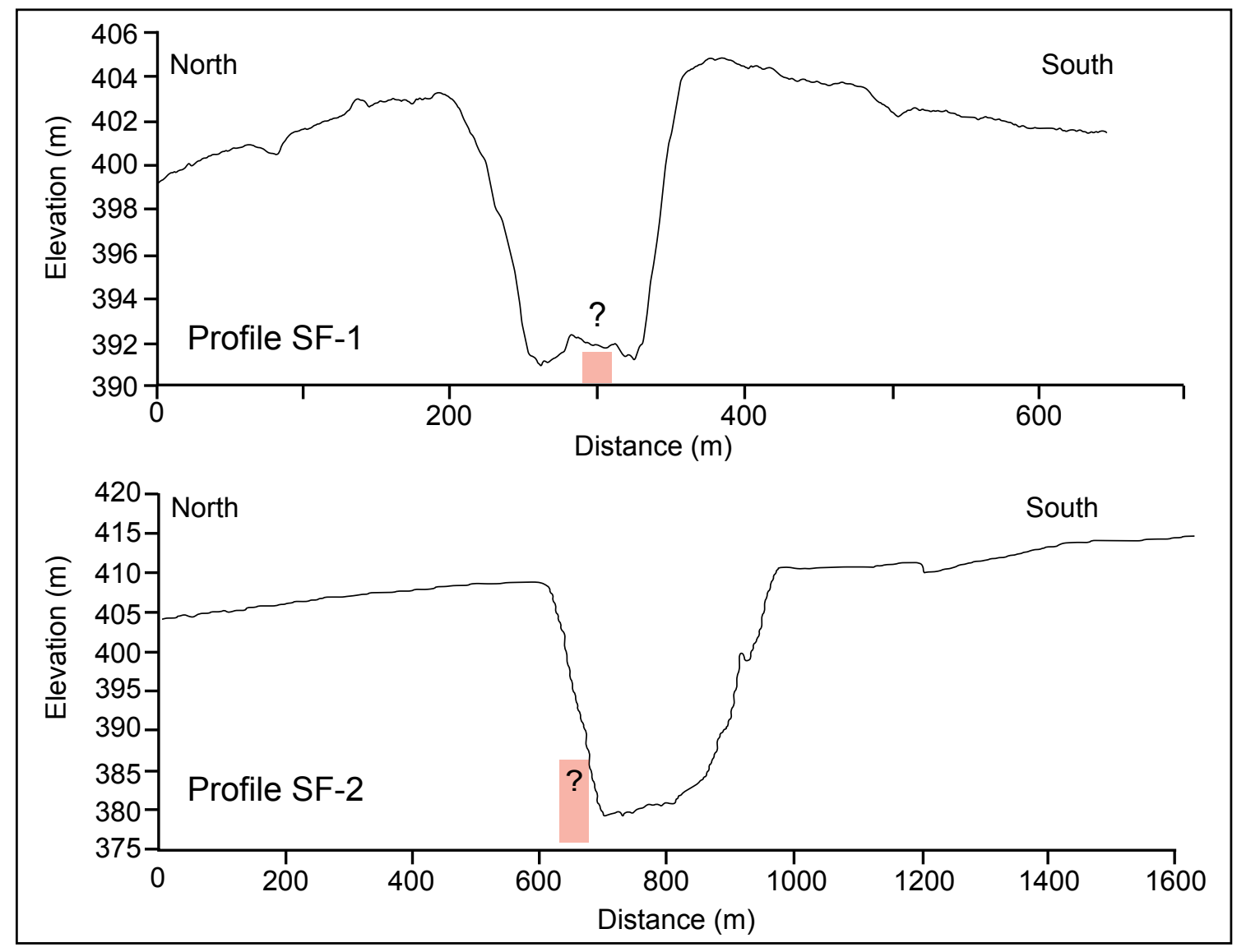

Figure 21. Topographic profiles across projected traces of the Stampede-Little Panguingue Creek fault. Projected trace of the fault shown by shaded rectangle on each profile. Profile locations shown on figure 19.

\subsubsection{Healy Creek Fault}

The potentially active 60-90 degree north-dipping reverse Healy Creek fault extends approximately $50 \mathrm{~km}$ from the Savage River in the west to the middle Healy Creek drainage in the east (Bemis and others, 2012; Koehler and others, 2012a) (fig. 9). The fault is a major element of the NFFTB. East of the Nenana River the location of the fault is well defined where it juxtaposes Precambrian Birch Creek Schist on the north against Tertiary Usibelli Group rocks and Plio-Pleistocene Nenana Gravel on the south and is associated with a north-side-up scarp in a Healy-aged glacial outwash deposit near Poker Creek (Wahrhaftig, 1970a; Bemis, 2010). West of the Nenana River the location of the fault is moderately defined and evidence for Quaternary activity includes vertical displacement of Lignite Creek ( 130-191 ka) and older glacial deposits (Bemis, 2010).

The fault crosses the proposed pipeline route near MP 519.33 at an orientation of 270 degrees (fig. 22); however, the fault is not defined in surficial deposits. Evaluation of the existing literature indicates that fault rupture parameters are poorly constrained. We performed helicopter reconnaissance of the Healy Creek fault along its entire mapped length, and surficial-geologic mapping in the vicinity of the Nenana River and proposed pipeline crossing. To assess the fault's activity topographic profiles were constructed from lidar data across the fault where it extends across Healy- and Riley Creek-aged glacial outwash deposits near the pipeline and from topographic data across relatively older glacial deposits west of the proposed pipeline route.

Topographic analyses and trenching performed by Bemis (2010) provide the only detailed information on the relative activity of the Healy Creek fault. Bemis's study expanded earlier efforts to understand the fault's structural history (Bemis, 2004; Bemis and Wallace, 2007). Topographic profiles constructed by Bemis (2010) across late Pleistocene terrace surfaces that cross the Healy Creek fault just west of the Nenana River near the Parks Highway, determined that the surfaces were not deformed. Profiles constructed west of the Parks Highway across Lignite Creek glacial moraines determined that the moraines were offset 70-80 m across the fault (Bemis, 2010). Farther west, Bemis (2010) determined 


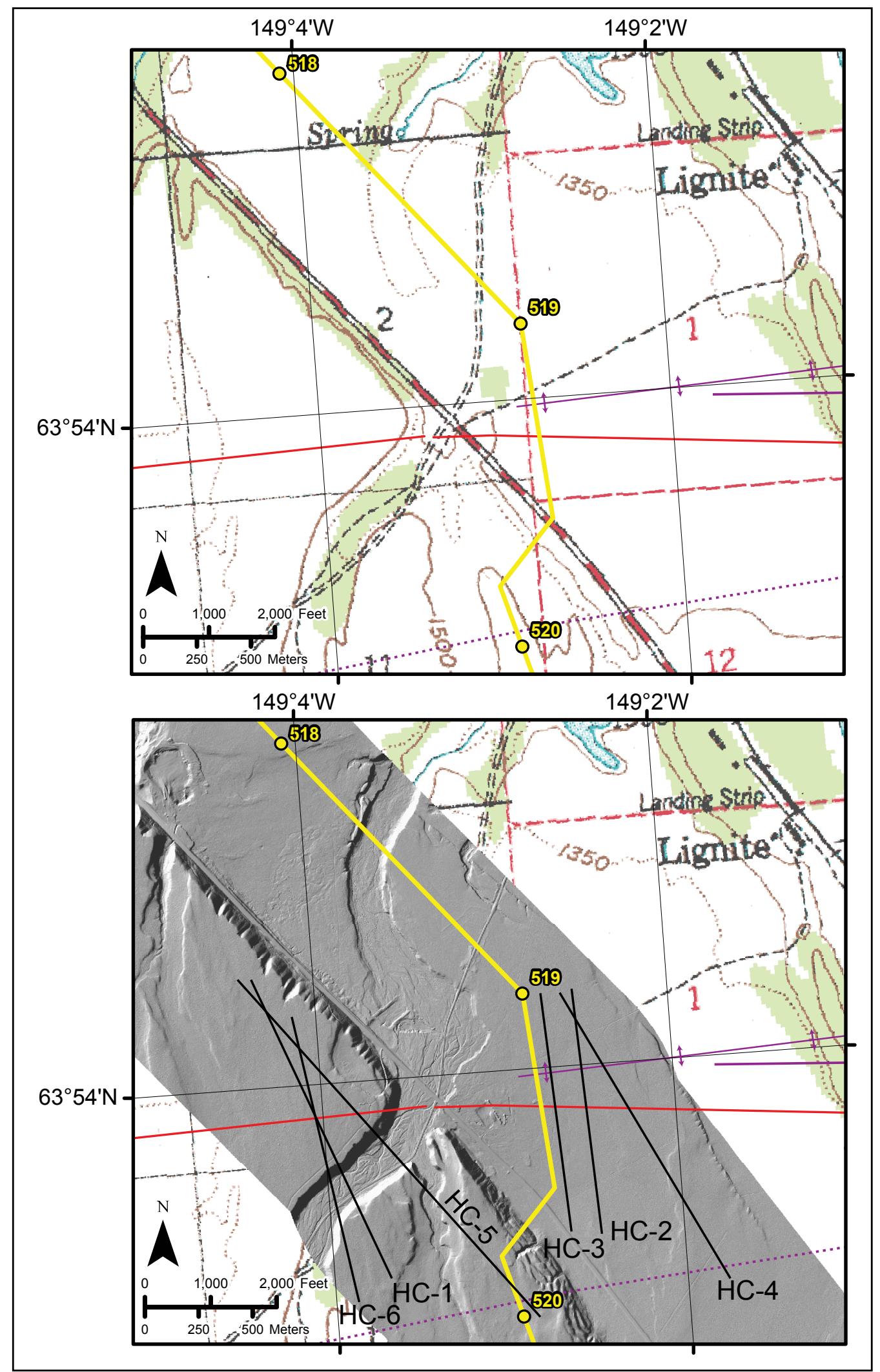

Figure 22. Topographic map (top) and lidar hillshade (bottom), showing the mapped trace of the Healy Creek fault (red line, Koehler and others, 2012a) in the vicinity of the proposed ASAP pipeline crossing. Previously-mapped structures that have been shown to not be active during the Holocene are shown in purple; see Appendix A for references. Proposed pipeline route shown in yellow. Black lines indicate locations of topographic profiles HC- 1 through HC- 6 shown in figures 25 and 26 . For reference, MP 519 is located at GPS coordinates $63.903^{\circ} \mathrm{N}, 149.047^{\circ} \mathrm{W}$. 
that surface displacements of relatively older glacial deposits decrease to the southwest and that the Nenana Gravel was deformed into a 50-m-high anticline. These observations were used to infer that slip on the Healy fault could transfer to the Stampede fault to the north and west.

Cross-fault paleoseismic trenching in Healy-aged outwash gravels (as mapped by Wahrhaftig, 1970a) east of the Nenana River near Poker Creek revealed the presence of numerous steeply-dipping shear zones that cut the gravel (Bemis, 2010). Although no stratigraphic log is presented, Bemis (2010) infers the possible occurrence of an earthquake near the end of the Pleistocene based on an angular unconformity in a loess deposit that buries the gravel and a thin colluvial deposit. A second trench at the site, excavated across a channel inset into the gravels, did not reveal evidence of tectonic deformation. Thus it was inferred that the fault has not generated a surface rupture for at least 7,000 years (Bemis, 2010).

During our aerial surveys we confirmed the presence of south-facing escarpments and uplifted glacial surfaces along the Healy Creek fault west of the Nenana River (figs. 23A and B). Additionally, we observed the well-defined scarp near Poker Creek and a subtle south-facing escarpment between bedrock and Nenana Gravel in a saddle directly west of the headwaters of Gagnon Creek (figs. 23C and D). Lidar, aerial photography, and field observations are the basis for our surficial-geologic mapping in the vicinity of the proposed pipeline route near the Healy Creek fault, shown in figure 24 .
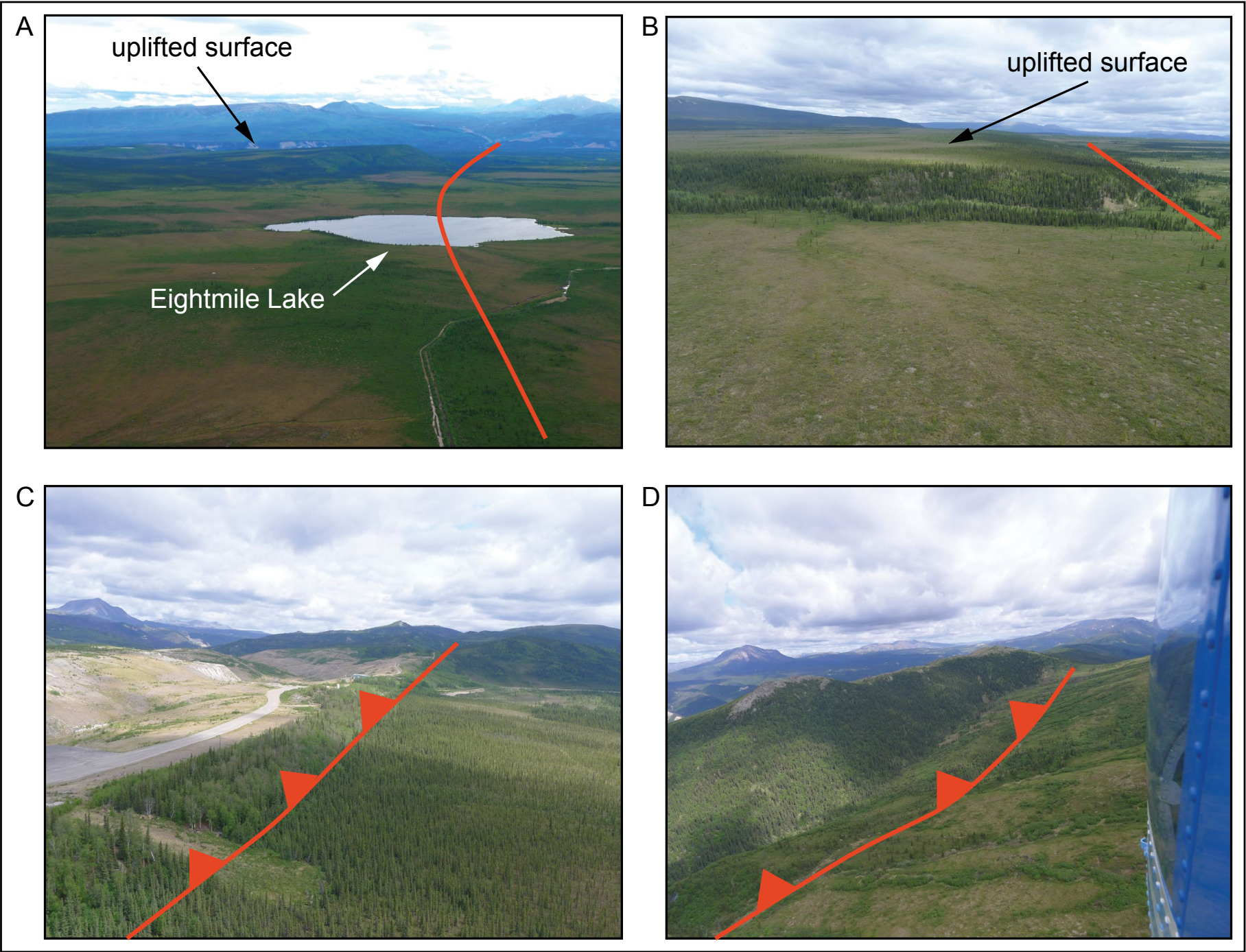

Figure 23. Aerial photographs along the Healy Creek fault; approximate location of fault is shown in red in each photo. A. Uplifted and backtilted surface near Eightmile Lake. View to west from GPS coordinates $63.892^{\circ} \mathrm{N}, 149.214^{\circ} \mathrm{W}$. B. Uplifted surface west of Eightmile Lake. View to east from GPS coordinates $63.873^{\circ} \mathrm{N}, 149.361^{\circ} \mathrm{W}$. C. Possible scarp directly east of the Nenana River. View to northeast from GPS coordinates $63.891^{\circ} \mathrm{N}, 148.967^{\circ} \mathrm{W}$. D. Subtle linear trough near saddle, with Birch Creek Schist juxtaposed against Nenana Gravel across the fault. View to northeast from GPS coordinates $63.892^{\circ} \mathrm{N}, 148.819^{\circ} \mathrm{W}$. 
Our aerial, lidar, and field investigations revealed that the fault is not expressed in surficial deposits in the vicinity of the proposed pipeline route.

Topographic profiles HC-1, HC-5, and HC-6, west of the proposed pipeline crossing, indicate that the Healy-aged outwash terrace is relatively flat along the mapped trace of the fault (fig. 25). The surface south of the fault is between 5 and $10 \mathrm{~m}$ lower and also flat, from which we infer that the difference in elevation might not be tectonic and instead could be

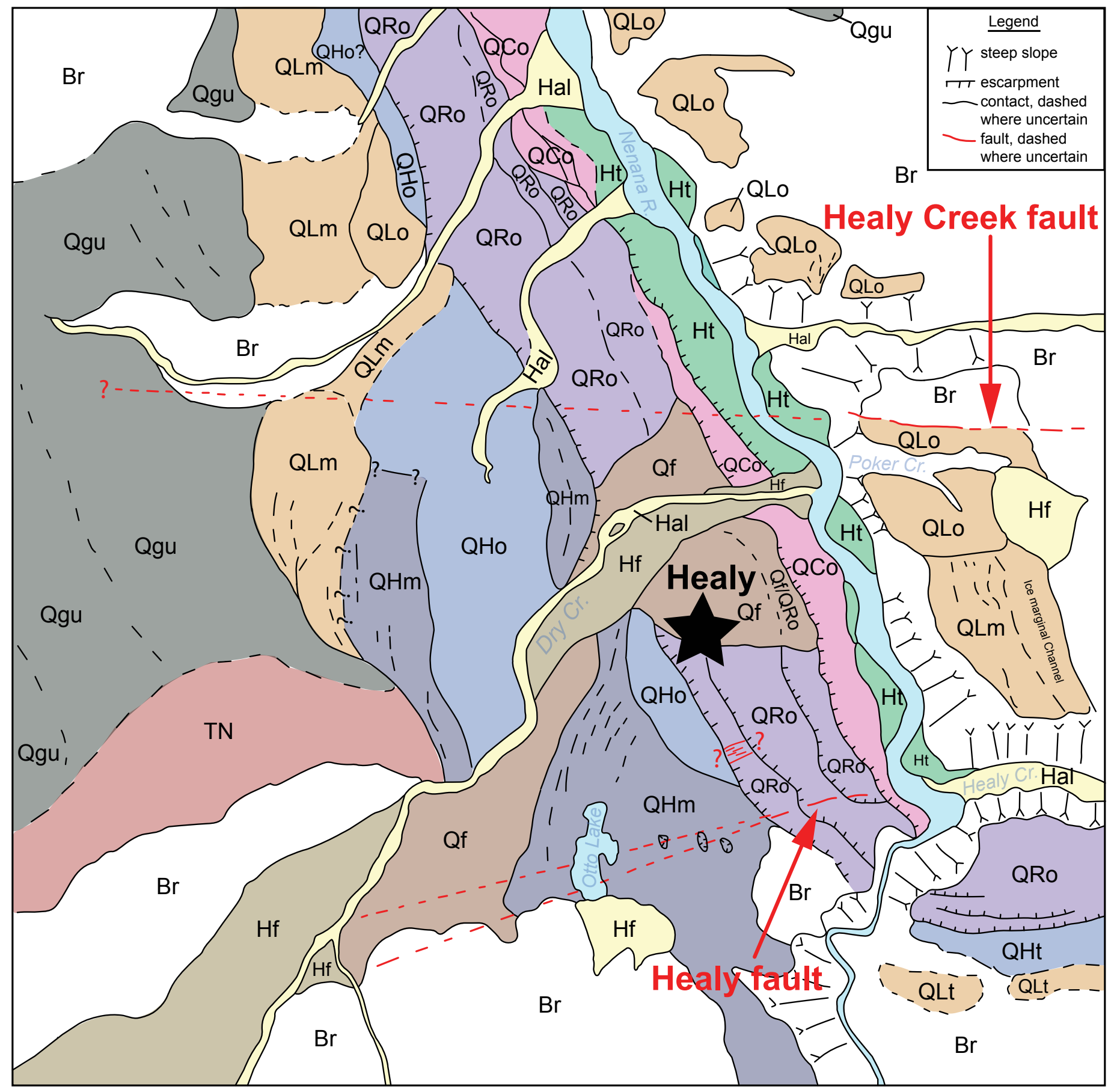

Figure 24. Surficial-geologic map of the Healy area, showing the Healy and Healy Creek faults and deposits discussed in the text. Location of map shown on figure $9 . \mathrm{Br}=$ bedrock; $\mathrm{TN}=$ Tertiary Nenana gravel; Qgu = glacial deposits, undifferentiated; QLt = till deposits of the Lignite Creek glaciation; QLm = glacial moraines of the Lignite Creek glaciation; QLo = outwash deposits of the Lignite Creek glaciation; $\mathrm{QHm}=$ glacial moraines of the Healy glaciation; $\mathrm{QHo}=$ outwash deposits of the Healy glaciation; $\mathrm{QRo}=$ outwash deposits of the Riley Creek glaciation; QCo = outwash deposits of the Carlo Creek advance; Qf = Quaternary alluvial fan deposits; $\mathrm{Hf}=$ Holocene alluvial fan deposits; $\mathrm{Ht}=$ Holocene fluvial terrace deposits; $\mathrm{Hal}=$ Holocene alluvial deposits. 
related to alluvial-fan erosion, analogous with the conclusion of Bemis (2010). Profiles HC-2 and HC-3, adjacent to the proposed pipeline, indicate that the Riley Creek-aged outwash terrace gently slopes to the north across the mapped trace of the fault and is not deformed (fig. 26). Profile HC-4, across the same surface, shows a subtle change in slope at the mapped trace of the fault; however, the surface is not higher north of the fault. A small, $\sim 1-\mathrm{m}$-high mound south of the fault on Profile HC-4 is interpreted to be a fluvial levee related to surface flow across the terrace when it was the active fluvial surface. Figure 27 shows a profile constructed from topographic data across the fault where it offsets an undated glacial deposit that predates the Lignite Creek glaciation. We tentatively assign a poorly constrained age of Marine Isotope Stage $8(\sim 300 \mathrm{ka})$ to this glacial deposit. If correct, the $130 \mathrm{~m}$ offset across the fault implies a vertical slip rate of $0.4 \mathrm{~mm} /$ yr. Using the 70-80 m offset of Lignite Creek-aged moraines ( 130-191 ka) described by Bemis (2010), a vertical slip rate of $0.4-0.6 \mathrm{~mm} / \mathrm{yr}$ can be inferred.

Our surficial-geologic mapping generally agrees with previously published interpretations of the Quaternary geology (Wahrhaftig, 1970a), with one exception. We interpret the high surface near Poker Creek east of the Nenana River to be associated with the Lignite Creek glaciation (fig. 24), in contrast to the previous association with the Healy glaciation. Our interpretation is based on the elevation of moraines in the Poker Creek headwaters that are approximately $60 \mathrm{~m}$ higher than the Healy-aged moraine at the mouth of the Nenana River canyon. These moraines are the source of the outwash gravels at Poker Creek and roughly correlate to moraines on the west side of the Nenana River that are also correlated to the Lignite Creek Glaciation. If this observation is correct it implies that the Healy Creek fault scarp near Poker Creek could be older than previously thought and therefore consistent with the apparent lack of deformation of Healy-aged fluvial terrace surfaces west of the Nenana River. We also propose the possibility that the scarp could be the product of outwash erosion.

Based on the evidence described above we infer that the most recent surface deformation along the Healy Creek fault could postdate deposition of the Healy ( $70 \mathrm{ka}$ ) outwash deposits near Poker Creek; however, that deposit could be as old as $\sim 130-191 \mathrm{ka}$ and associated with the Lignite Creek glaciation. The fault does not deform Riley Creek-aged $(<17 \mathrm{ka})$ fluvial terraces, and thus has not been active during the Holocene along the proposed pipeline route. Despite the apparent lack of Holocene activity, the potential for future ruptures along the Healy Creek fault is unknown, and fault rupture parameters are poorly constrained. We did not observe evidence of a late Pleistocene earthquake as documented by Bemis (2010) during our field surveys, but acknowledge that profile analyses are an indirect method of assessing fault activity.

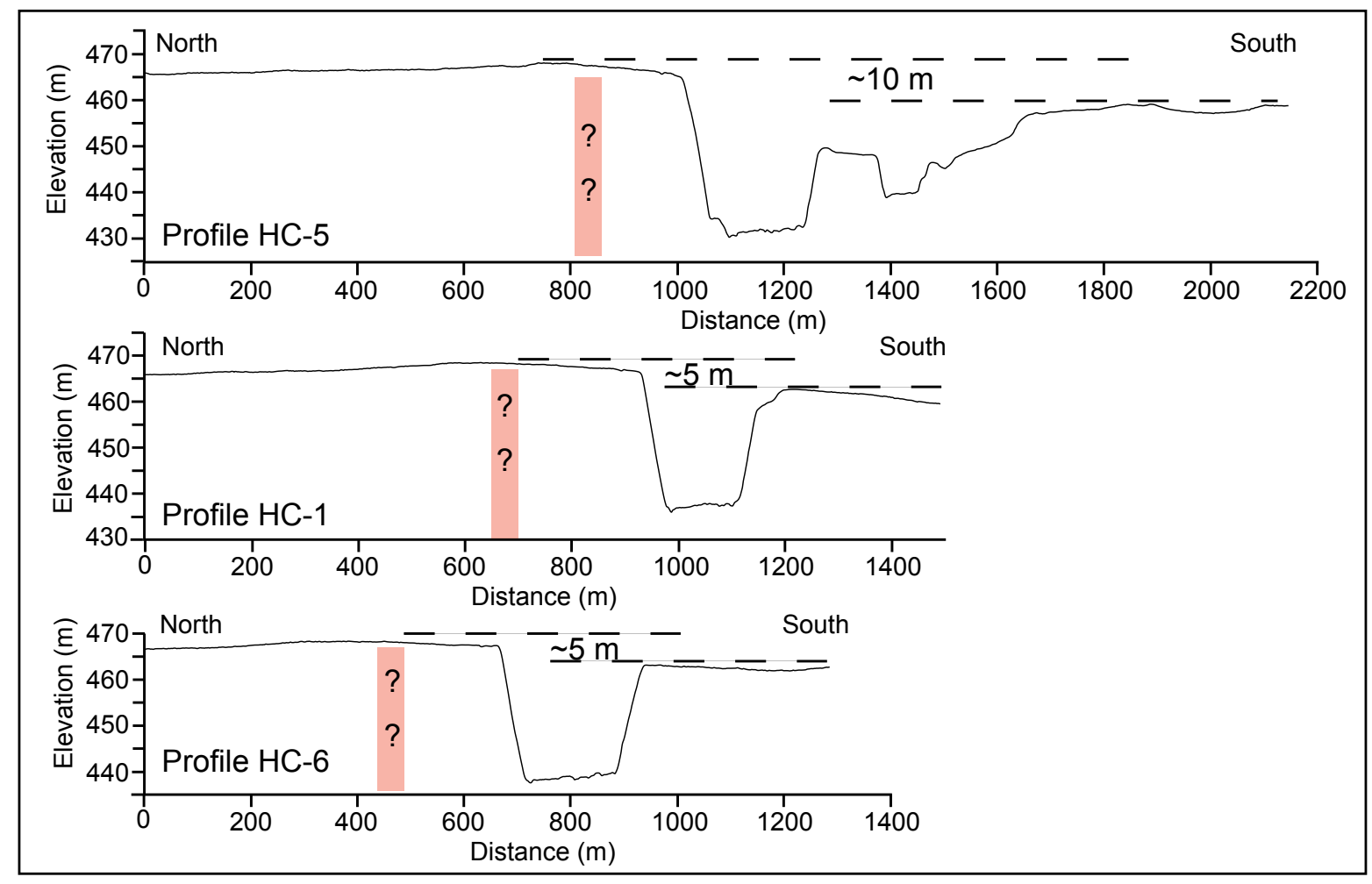

Figure 25. Topographic profiles across Healy-aged outwash terrace surface in the vicinity of the Healy Creek fault. Shaded rectangles indicate inferred locations of the fault. Profile locations shown on figure 22. 


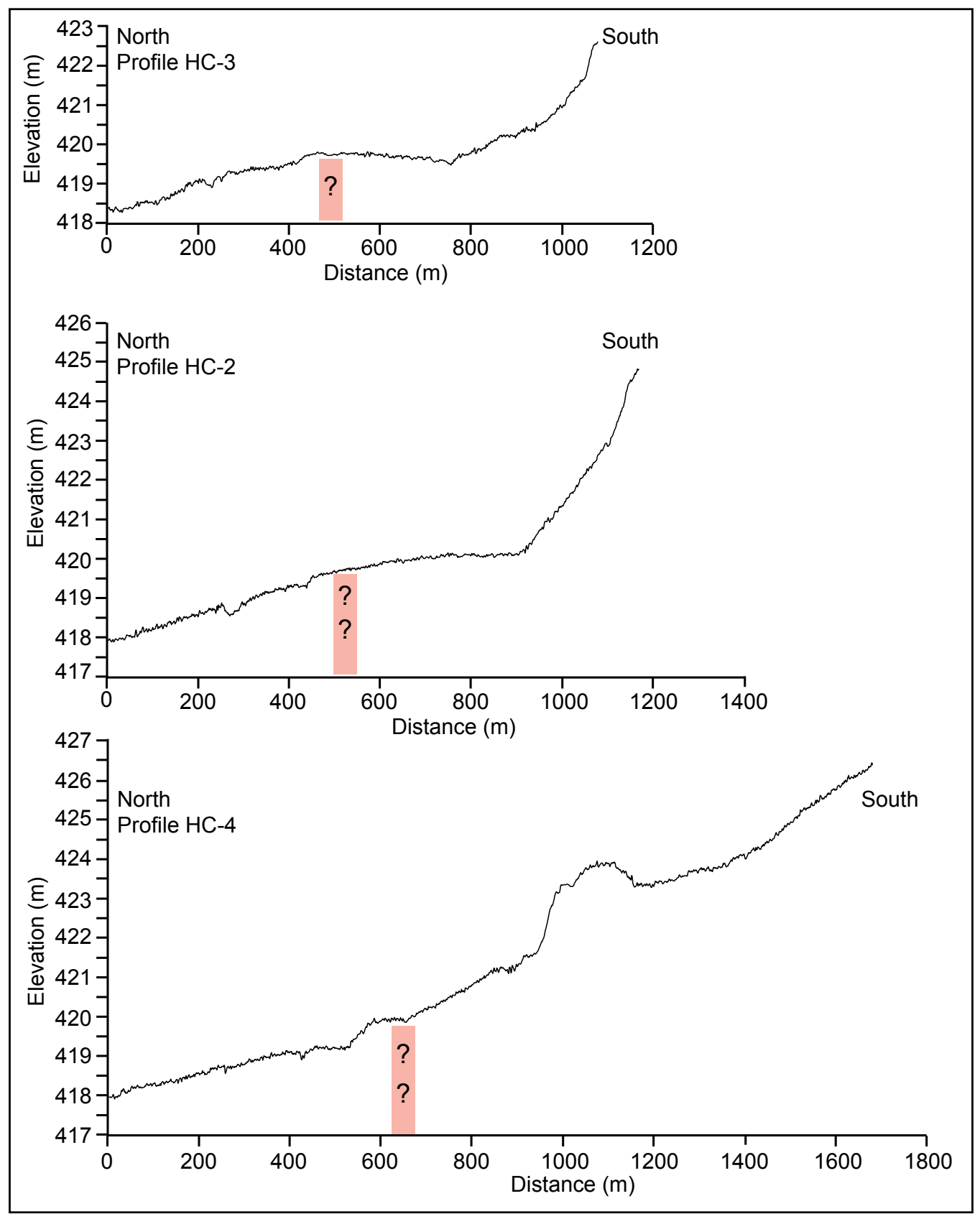

Figure 26. Topographic profiles across Riley Creek-aged outwash terrace surface in the vicinity of the mapped trace of Healy Creek fault. Shaded rectangles indicate inferred locations of the fault. Profile locations shown on figure 22. 


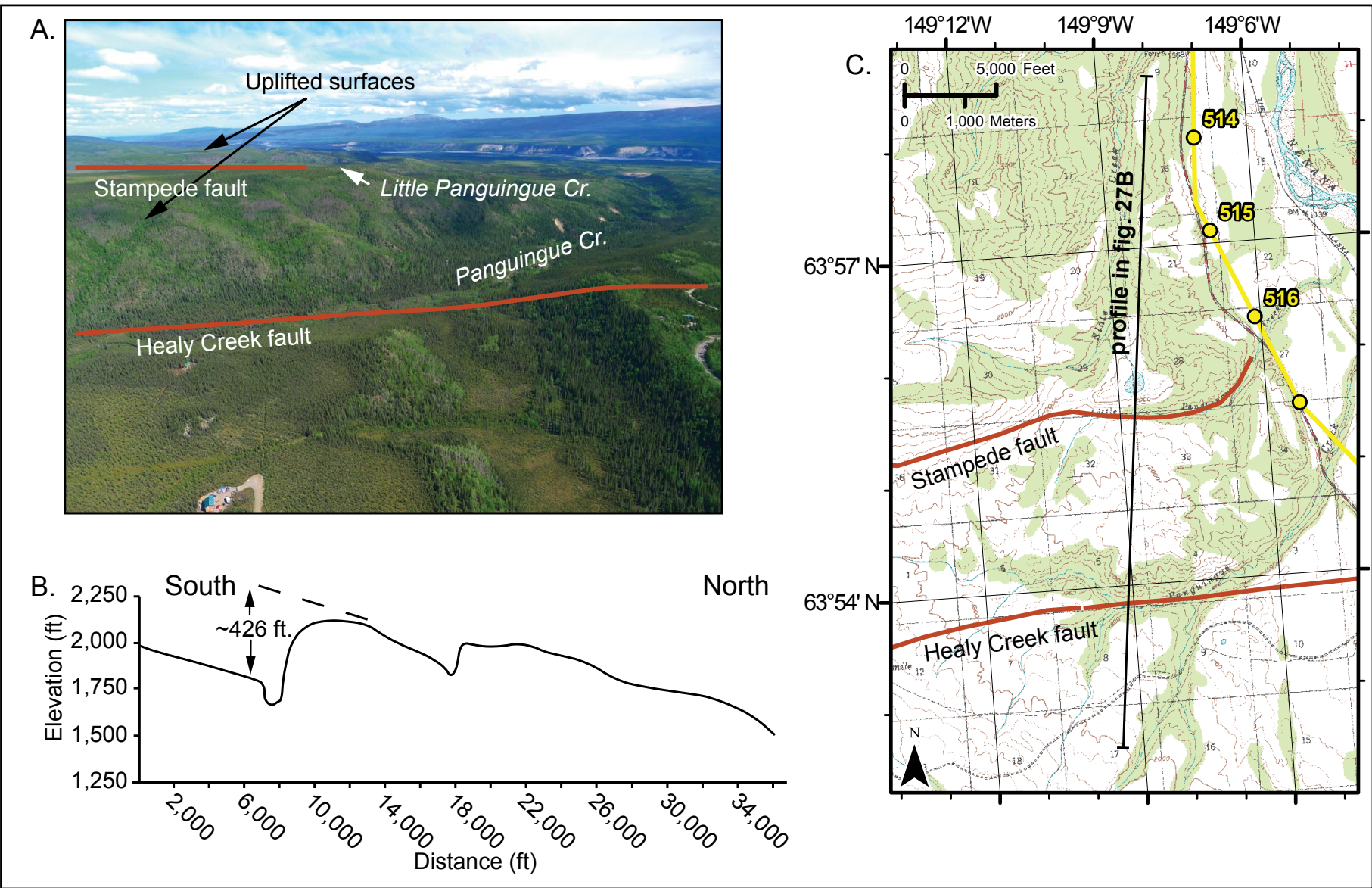

Figure 27. A. View to north of the Healy Creek and Stampede faults (red lines), showing uplifted surfaces directly west of the proposed pipeline route. View is along profile shown in B and taken from helicopter near GPS coordinates $63.879^{\circ} \mathrm{N}, 149.13^{\circ} \mathrm{W}$. C. Location of profile B shown on topographic map. Stampede and Healy Creek faults shown in orange.

\subsubsection{Healy Fault}

The trace of the potentially active Healy fault is mapped several kilometers north of the town of Healy, where it extends $1.5 \mathrm{~km}$ at an orientation of 250 degrees westward from the west bank of the Nenana River near the Healy airport to moraine deposits associated with the $\sim 60$ ka Healy glaciation (Thorson, 1979) (figs. 9 and 28). There the fault is associated with a clear, linear, south-facing scarp that extends across several nested fluvial terraces that postdate the Riley Creek glaciation and three roughly aligned beaver ponds along the base of the scarp (fig. 28). The fault projects toward the proposed pipeline route in the vicinity of MP 524 but has not been mapped previously at the crossing (fig. 29).

Thorson (1979) initially interpreted the fault as a south-side-down normal fault and proposed recurrent late Quaternary displacements along two discontinuous scarps that offset Riley Creek outwash terraces. At the western margin of the modern Nenana River floodplain Thorson (1979, fig. 2) proposed the coincidence of the Healy fault and a 12-m-deep gully, across which the north block is $\sim 2 \mathrm{~m}$ higher than the south block. Thorson (1979, fig. 3) illustrated a major shear zone striking roughly perpendicular to the proposed Healy fault in a steeply-dipping sequence of coal beds in sandstone, pebbly sandstone, and claystone in the north wall of the gully, and shows $\sim 4 \mathrm{~m}$ of west-side-down displacement of coarse gravel across that shear zone.

In more recent studies (Bemis, 2004; Bemis and others, 2012) the fault was reinterpreted as a Holocene-active, north-dipping $\left(45^{\circ}\right)$ reverse fault. Based on stratigraphic relations exposed in a paleoseismic trench, Bemis (2010) inferred at least three earthquakes that postdate deposition of a fluvial outwash terrace of Riley Creek-aged glaciation and deduced that the most recent earthquake occurred sometime during the years 1,528-1,176 cal yr BP. The cumulative brittle offset observed in the trench was less than $\sim 1.5 \mathrm{~m}$, from which Bemis (2010) concluded that much of the deformation was due to folding. Based on inspection of the trench logs, we suggest the possibility that complicated stratigraphy and cryoturbation processes could have limited the interpretation of multiple surface-rupturing earthquakes in the trenches of Bemis (2010). 
Figure 28. Aerial photographs of the Healy fault. A. Healy fault (shown in red) as mapped by Thorson (1979) between the Nenana River and moraine of Healy glaciation. Photograph taken from helicopter looking west from GPS coordinates $63.849^{\circ} \mathrm{N}, 148.945^{\circ} \mathrm{W}$. B. Healy fault scarp across fluvial terrace; arrows point to scarp. Photograph taken from helicopter looking northwest from GPS coordinates $63.849^{\circ} \mathrm{N}, 148.965^{\circ} \mathrm{W}$.

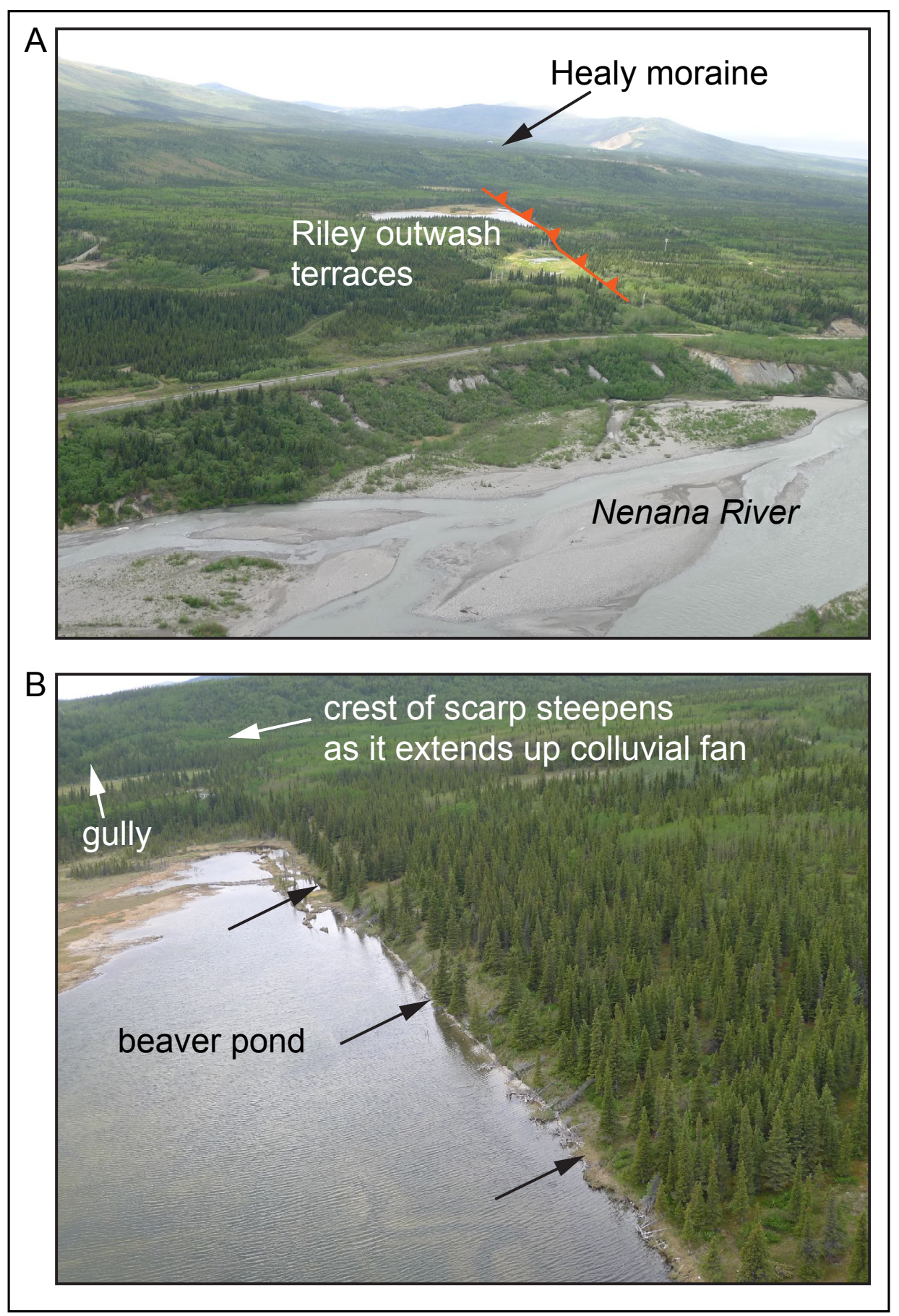

We performed surficial-geologic mapping (fig. 24) and ground reconnaissance in the vicinity of Healy to evaluate the projection of the fault and assess previous interpretations of the fault as an active tectonic structure. Along the western margin of the Nenana River floodplain on the projection of the fault, bedrock exposures in the north wall of a gully show thin bedrock shear zones that roughly parallel steeply-dipping coal beds in the undifferentiated Grubstake and Lignite Creek Formations. Although there is considerable alteration of the ground surface by construction activities and the vegetation is dense, we inspected limited exposures of the basal contact of the coarse fluvial gravels where they overlie the bedrock at the top of the bluff and found no evidence of fault shearing or offset across the projection of the fault.

On the surface of the highest Riley Creek terrace the scarp is characterized by a rounded, gentle, north-facing slope about $3.4 \mathrm{~m}$ high extending over a horizontal distance of about $18 \mathrm{~m}$ (fig. 30). The basal $\sim 1.5 \mathrm{~m}$ of the scarp is steep and accentuated by erosion of beaver dam lakes. If the interpretation of Bemis (2010) is correct that at least three faulting events are responsible for the 3.4-m-high scarp, then individual faulting events might be characterized by relatively small displacements of possibly $\sim 1 \mathrm{~m}$ vertical per event. 


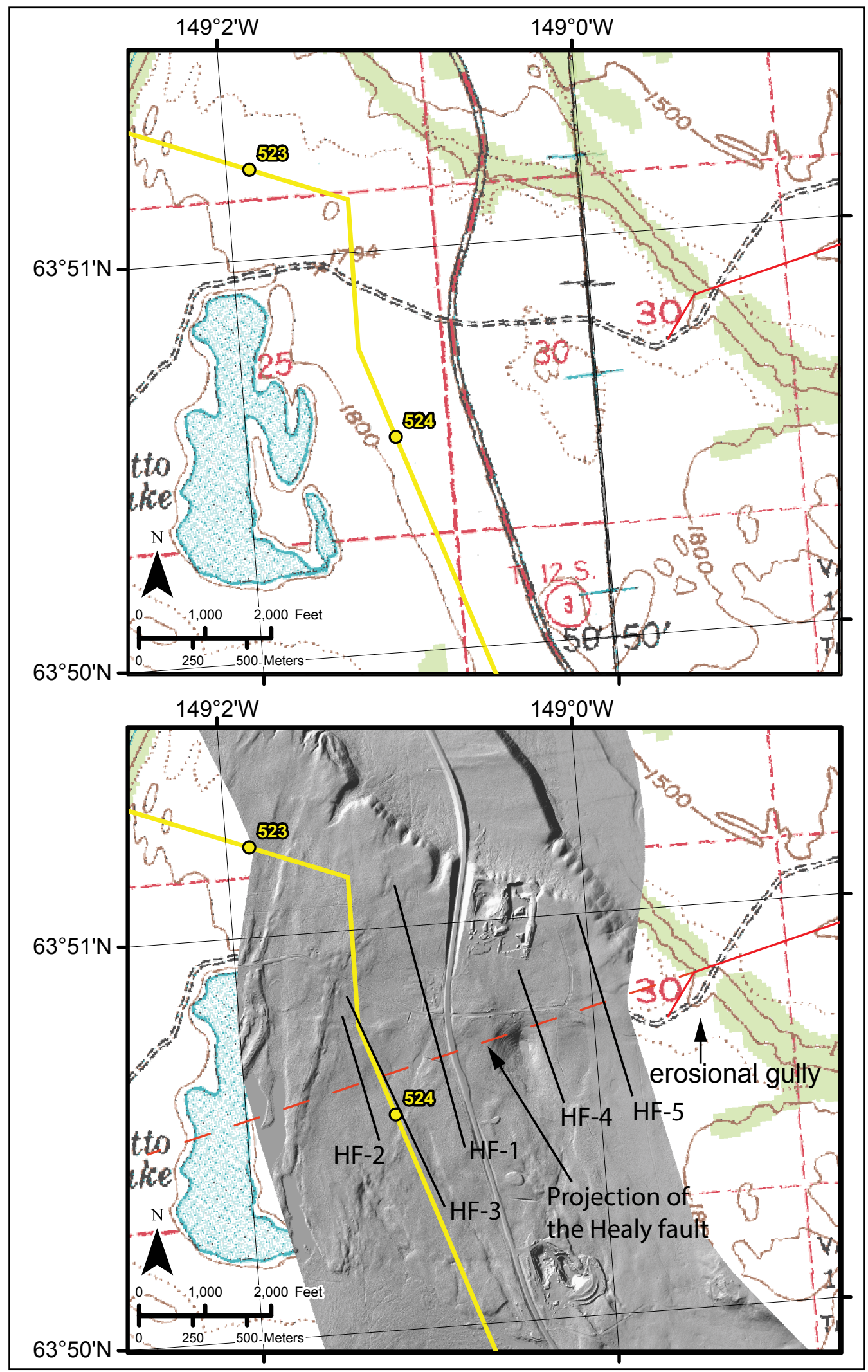

Figure 29. Topographic map (top) and lidar hillshade (bottom), showing proposed pipeline route (yellow) and previous mapping of the Healy fault shown by a red line east of lidar coverage (Koehler and others, 2012a). Projection of the Healy fault from the east is shown by a red dashed line (this study). Black lines indicate locations of topographic profiles HF-1 through HF-5 derived from lidar data and shown in figure 31. For reference, MP 524 is located at GPS coordinates $63.842^{\circ} \mathrm{N}, 149.019^{\circ} \mathrm{W}$. 


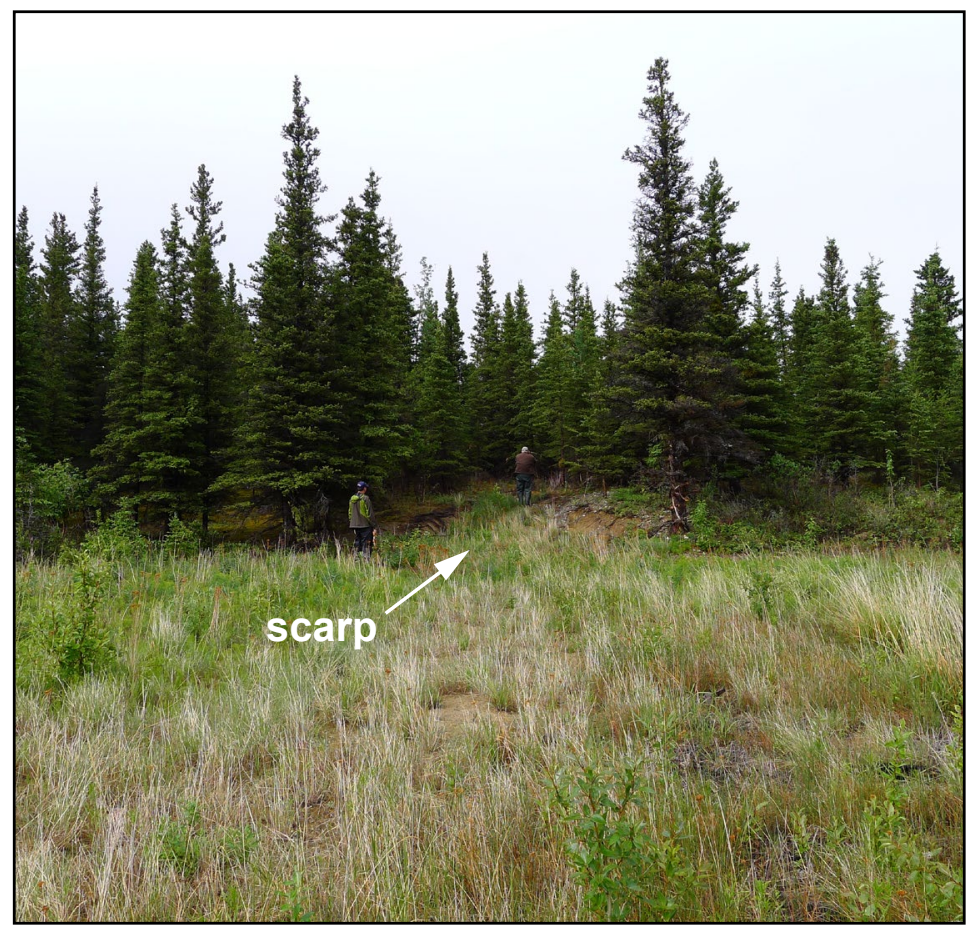

Figure 30. Healy fault scarp on the highest Riley Creek outwash surface. GPS coordinates $63.847^{\circ} \mathrm{N}, 148.986^{\circ} \mathrm{W}$.

At the western end of the mapped fault trace, the crest of the scarp gradually steepens in slope from $\sim 2$ degrees east to $\sim 10$ degrees east, and the trend of the fault scarp gradually bends toward the mouth of a large gully cutting through the high Healy-aged surface (fig. 28B). There a series of inset, channeled colluvial fans spread from the lower gully. Several subparallel gullies cut into the terrace tread north of the Healy fault scarp between the mouth of the large gully and the Nenana River. South of the gully in the Healy-aged deposits where Thorson $(1979$, fig. 1) mapped a second short fault, we found two springs emerging from the toe of the colluvial apron along the base of the high scarp, probably from the lower Healy outwash on the underlying Usibelli Group and not necessarily from a fault zone. The springs are the source of a vigorous clearwater stream that supplies water to the beaver ponds along the fault. The meandering stream could also be responsible for a prominent north-facing scarp to the south of and facing the Healy fault scarp on the Riley Creek terrace. Based on our ground observations, we suggest the possibility of an alternative interpretation for the origin of the Healy fault scarp as an erosional feature cut by drainages from the large gully to the west.

The short length of the mapped trace of the Healy fault is problematic because ruptures capable of breaking the surface are typically associated with longer mappable traces. However, we found no evidence that indicated surface displacement east of the Nenana River during our helicopter overflights. Additionally, surface and lidar-based observations across the projection of the fault where it would cross the Healy-aged moraine in the vicinity of the proposed pipeline route indicate that no clear surface trace of the fault is present (fig. 29). Similarly, topographic profiles constructed across the projection of the fault do not show a convincing continuous fault trace and indicate that the surface is hummocky and crossed by numerous broad, shallow swales (fig. 31). Profiles HF-1 and HF-2 show that the surface of the Healy moraine is relatively flat and gently north sloping, respectively, across the projected trace of the fault. Profiles HF-3 and HF-5 show a $\sim 2$ $\mathrm{m}$ and $\sim 1.25 \mathrm{~m}$ difference, respectively, in elevation of the surface across the projection of the fault. The projection of the fault on Profile HF-4 coincides with the margin of a thaw basin and does not show a clear separation of the surface. Although Profiles HF-3 and HF-5 show topographic relations that could be interpreted as surface displacement along the fault, Profiles HF-1 and HF-2 indicate that the apparent separation is not continuous. We conclude that the surface of the moraine is not a reliable datum from which to infer surface displacements due to the hummocky nature of the deposit and that the apparent offset shown on Profiles HF-3 and HF-5 are artifacts of complex morainal deposition and erosion. The relatively older Healy-aged surface should record progressively more deformation than the younger Riley Creek-aged outwash terrace, which is not observed.

The strike of the Healy fault is parallel to the orientation of bedding in the underlying Usibelli Group rocks, suggesting that the surface scarp on the Riley Creek-aged terraces could be related to flexural slip faulting resulting from anticlinal 


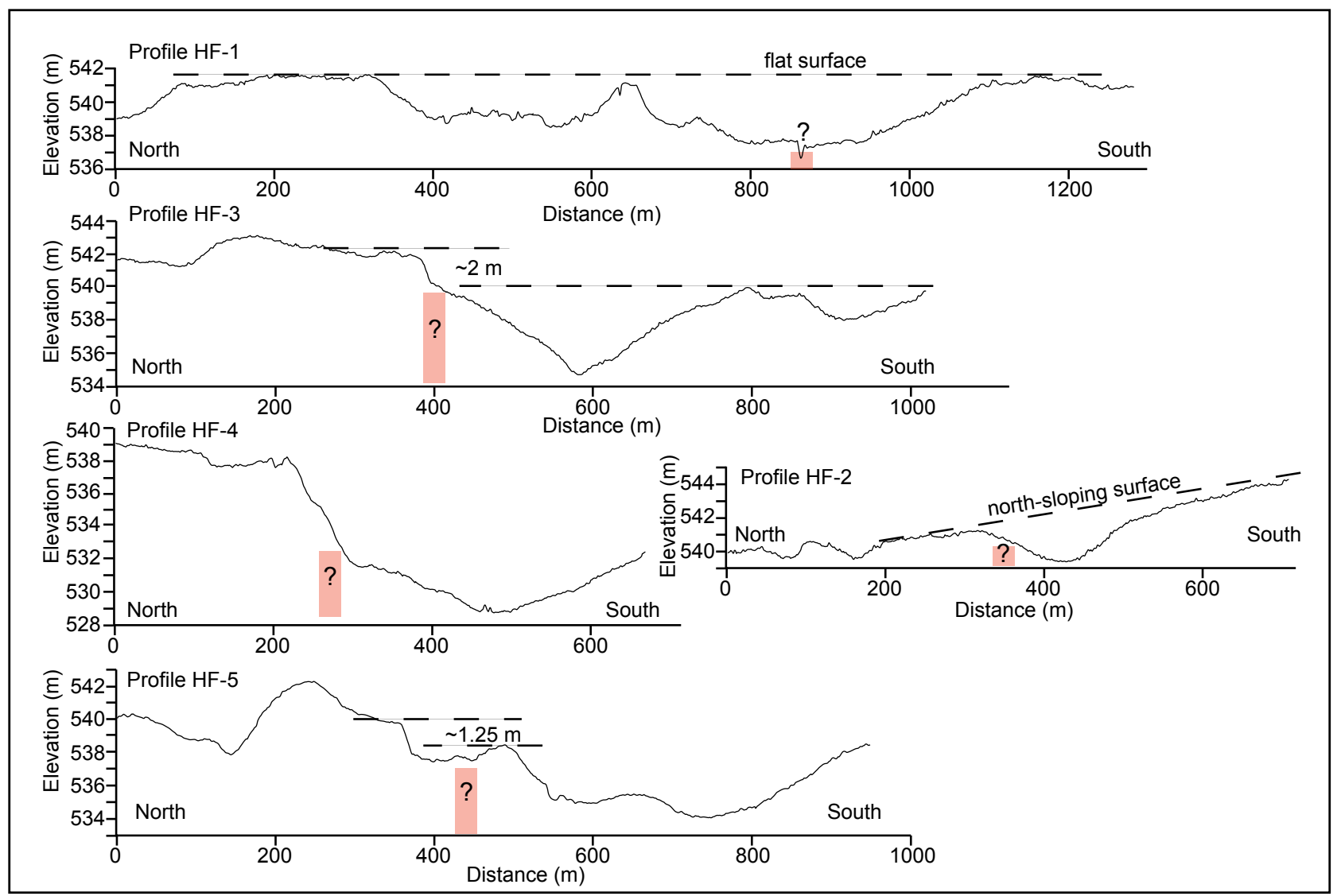

Figure 31. Topographic profiles across the projected trace of the Healy fault in the vicinity of the proposed pipeline route. Projected trace of the fault shown by shaded rectangles on each profile. Locations of profiles shown on figure 29.

growth north of the fault. Evidence of faulting in the local bedrock along the bank of the Nenana River could be caused by bedding-plane shearing that occurred during folding of the Usibelli Group and might or might not be seismogenic. It is possible that displacements on the fault are small enough to be absorbed by the thick Healy-aged moraine deposit and not be expressed on the surface.

Additional ground reconnaissance on private property owned by Usibelli Coal Mine, Inc., east of the Nenana River is warranted to confirm our interpretation of the lack of surficial offsets. Based on uncertainty in the origin of the scarp discussed above, we recommend further detailed stratigraphic evaluation in a large paleoseismic trench across the Healy fault to confirm the interpretation of surface displacement inferred by Bemis (2010) and to better characterize fault rupture parameters.

\subsubsection{Park Road Fault}

The active Park Road fault is the southernmost fault of the NFFTB and is a north-dipping reverse fault (backthrust). The fault extends roughly 75 degrees from the Sanctuary River in Denali National Park east to the upper Moody Creek drainage, for a total distance of approximately $65 \mathrm{~km}$. Uplift and folding in the hanging wall of the fault are responsible for the development of the Mount Healy anticline. Evidence for active deformation includes triangular facets along the northern flank of Mount Healy, progressively offset alluvial fans in the upper Moody Creek drainage, and offset glacial outwash and Holocene fluvial terraces (fig. 32). We performed helicopter reconnaissance along the entire fault, evaluated the fault on the ground on both sides of the Nenana River in the vicinity of the proposed crossing, and generated several profiles across the scarp.

The fault crosses the proposed pipeline route east of the Nenana River near the entrance to Denali National Park, where previous bedrock mapping shows several different interpretations of the location of the fault (fig. 33). The location of the active trace of the fault is clearly defined in lidar hillshade data west of the Nenana River, but is not evident at the crossing along Lynx Creek east of the river. Figure 34 shows our mapping of the fault and the width of the zone of deformation. Photographs of the scarp and topographic profiles across the scarp are shown in figures 35 and 36, respectively. 


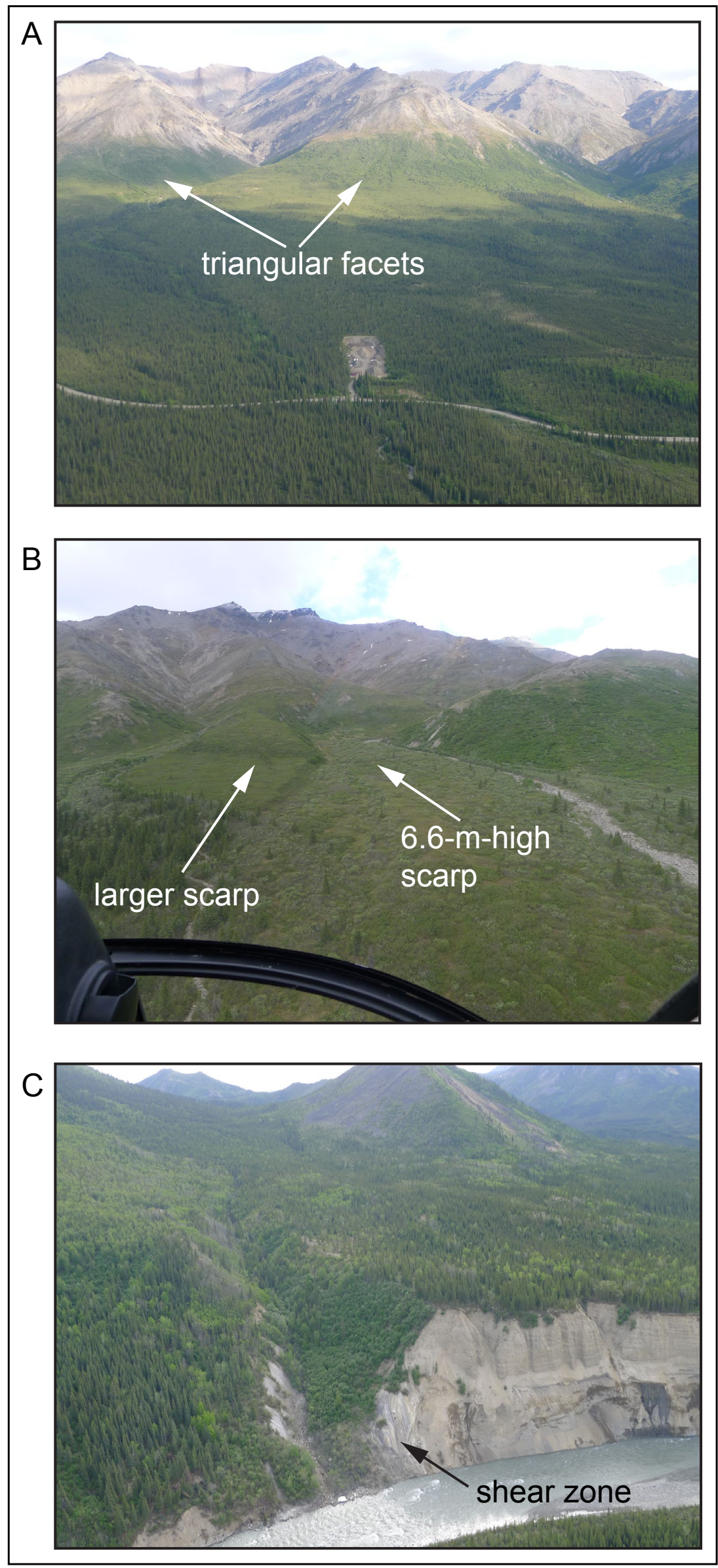

Figure 32. Tectonic geomorphology along the Park Road fault. A. Triangular facets along the north flank of the Mount Healy anticline. Photograph taken from helicopter from GPS coordinates $63.709^{\circ} \mathrm{N}, 149.04^{\circ} \mathrm{W}$. B. Progressively offset alluvial fans in the upper Moody Creek drainage. Photograph taken from helicopter looking north from GPS coordinates $63.784^{\circ} \mathrm{N}, 148.495^{\circ} \mathrm{N}$. C. Shear zone in bedrock along the fault at mouth of Lynx Creek. Photograph taken from helicopter looking east from GPS coordinates $63.73^{\circ} \mathrm{N}, 148.887^{\circ} \mathrm{W}$. 


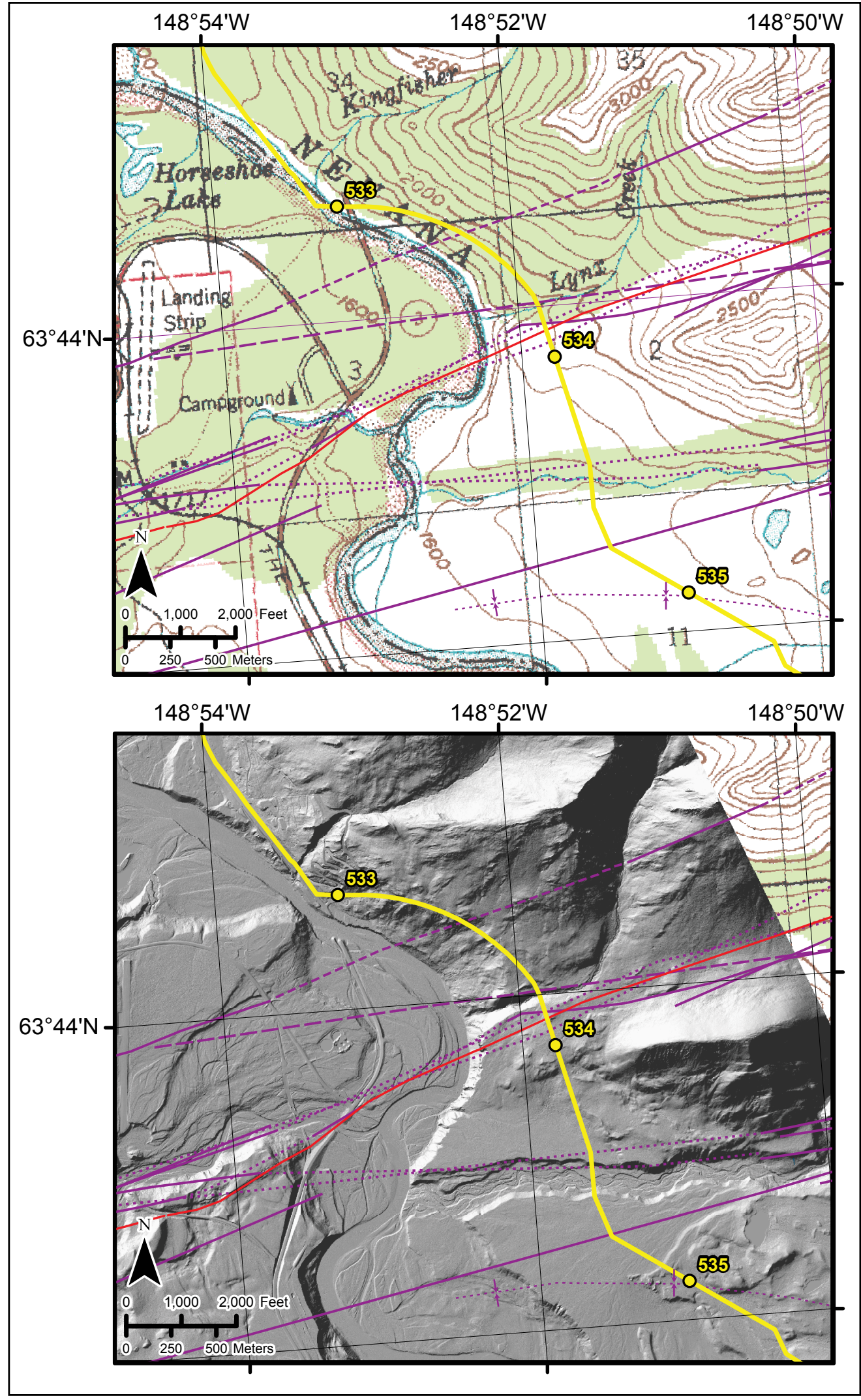

Figure 33. Topographic map (top) and lidar hillshade map (bottom), showing the mapped trace of the Park Road fault (red line; Koehler and others, 2012a) in the vicinity of the proposed ASAP pipeline crossing. A more accurate location of the fault based on projecting the orientation of the fault in the field is shown on figures 34 and 37. Previously-mapped structures that have been shown to be inactive during the Holocene are shown in purple; see Appendix A for references. Proposed pipeline route is shown by yellow line. For reference MP 534 is located at GPS coordinates $63.731^{\circ} \mathrm{N}$, $148.863^{\circ} \mathrm{W}$. 
Southwest of the Riley Creek bridge, the fault is expressed by a 12-m-high scarp that cuts an outwash terrace of the Riley Creek glaciation and a large landslide. There the scarp is characterized by an oversteepened base and 2-m-deep fissures in the hanging wall. The cumulative width of folding is distributed over about $80 \mathrm{~m}$. Assuming that the age of the terrace postdates the maximum Riley Creek glacial advance around $\sim 17 \mathrm{ka}$ (Ten Brink and Waythomas, 1985), the height of the scarp suggests the minimum late Pleistocene uplift rate for the Park Road fault is $\sim 0.7 \mathrm{~mm} / \mathrm{yr}$. Northeast of the Riley Creek bridge, the fault cuts a Holocene fluvial terrace of the Nenana River, where it is associated with a 2- to 2.5-m-high scarp and $\sim 1$-m-deep hanging wall fissures. The width of deformation associated with the offset fluvial terrace is distributed over $30 \mathrm{~m}$. Where the Holocene scarp is smooth, it is unbeveled, suggesting it is the result of a single displacement event; therefore the scarp height represents a good approximation for deformation in the next earthquake $(2.5 \mathrm{~m}$ vertical surface displacement and distributed folding and fissuring over a distance of $30 \mathrm{~m}$ north of the fault).

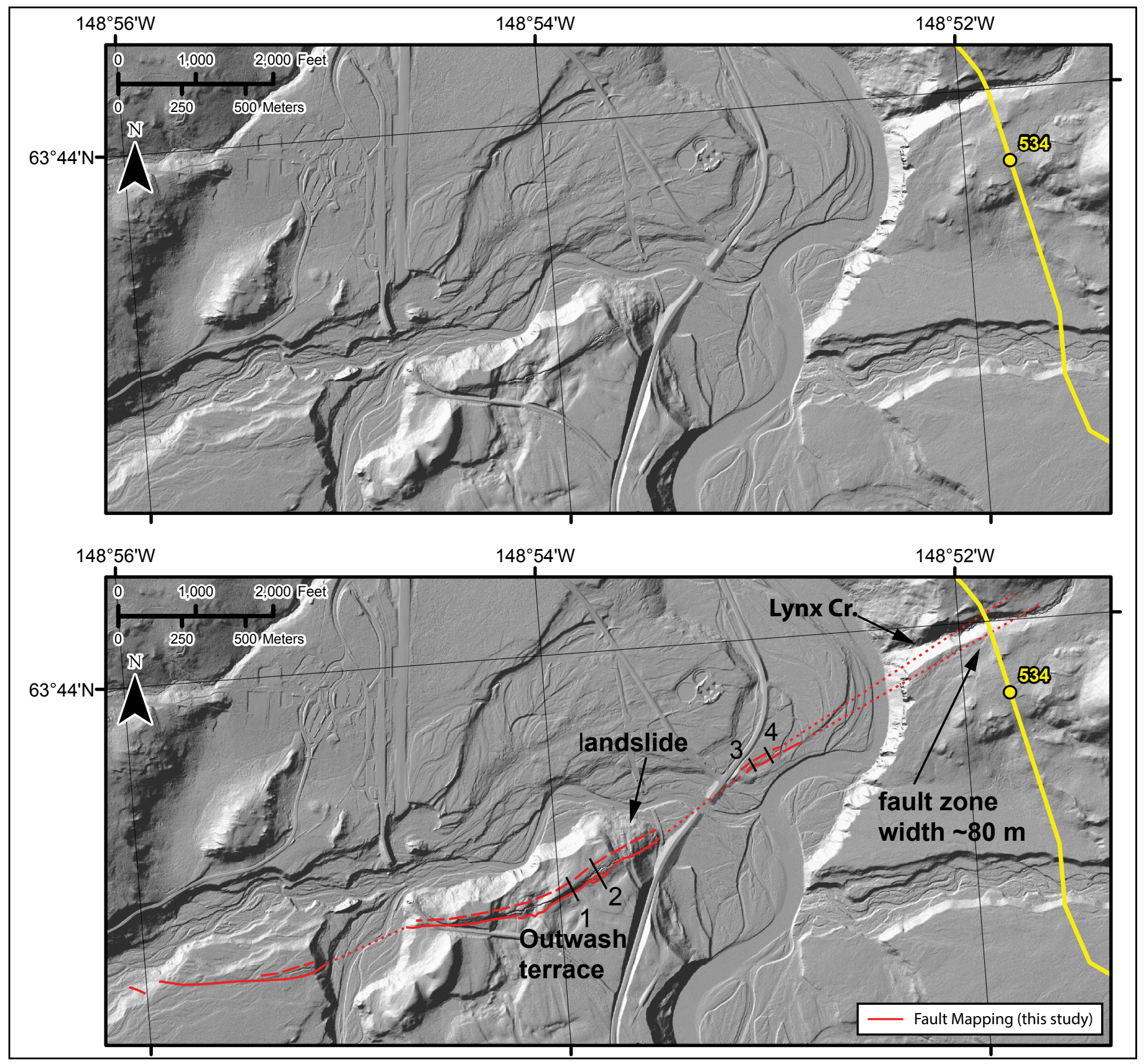

Figure 34. Lidar hillshade images of the Park Road fault, showing uninterpreted image (top) and fault mapping performed for this project (bottom). Dotted red lines show the projection of the fault zone toward the proposed pipeline crossing. Width of projected fault zone at the crossing is about $78 \mathrm{~m}$. Numbered black lines mark locations of Park Road profiles 1-4, which are shown in figure 36 . For reference MP 534 is located at GPS coordinates $63.731^{\circ} \mathrm{N}, 148.863^{\circ} \mathrm{W}$. 
The dip of the fault in the shallow subsurface is poorly constrained. Inspection of a balanced cross section (Bemis and Wallace, 2007) indicates that the fault dips north approximately 45 degrees in the upper several kilometers. At the surface, narrowly aligned fissures on the crest of the scarp at the Riley Creek outwash terrace and the apparent lack of lateral displacement of the margin of the landslide deposit (fig. 34) suggest that the fault steepens in the shallow subsurface and could be close to vertical. This is consistent with the nearly vertical shear zone exposed in the east canyon wall of the Nenana River (fig. 32C). The wide zone of folding and fissuring along the scarp at the faulted Holocene terrace suggests that the dip could locally flatten in the upper several meters where it cuts unconsolidated deposits.

Surficial-geologic mapping east of the Nenana River on both sides of the Lynx Creek gorge verified the lidar observations that no fault scarp is present along the projection of the fault (fig. 37). South of the gorge, surficial till of the Riley Creek glaciation and isolated morainal deposits with scattered glacial erratics up to $3 \mathrm{~m}$ in diameter were noted. The elevation of the north side of the gorge is higher than the south side, possibly due to uplift along the Park Road fault. Sheared bedrock is exposed adjacent to the Nenana River in the south wall of the Lynx Creek gorge and we infer that the fault extends through this outcrop and up the gorge. Vigorous landslide activity in the Lynx Creek gorge has likely buried or removed the fault scarp; east of the gorge, the trace of the fault is likely masked by slope colluvium. Based on projections of the fault and the zone of deformation from the west, we estimate that the zone of deformation associated with the Park Road fault is confined to the Lynx Creek gorge at the proposed pipeline crossing, a width of $80 \mathrm{~m}$ between MP 533.79 and MP 533.86 (fig. 37). At the crossing, the projected fault zone has an orientation of 235 degrees.

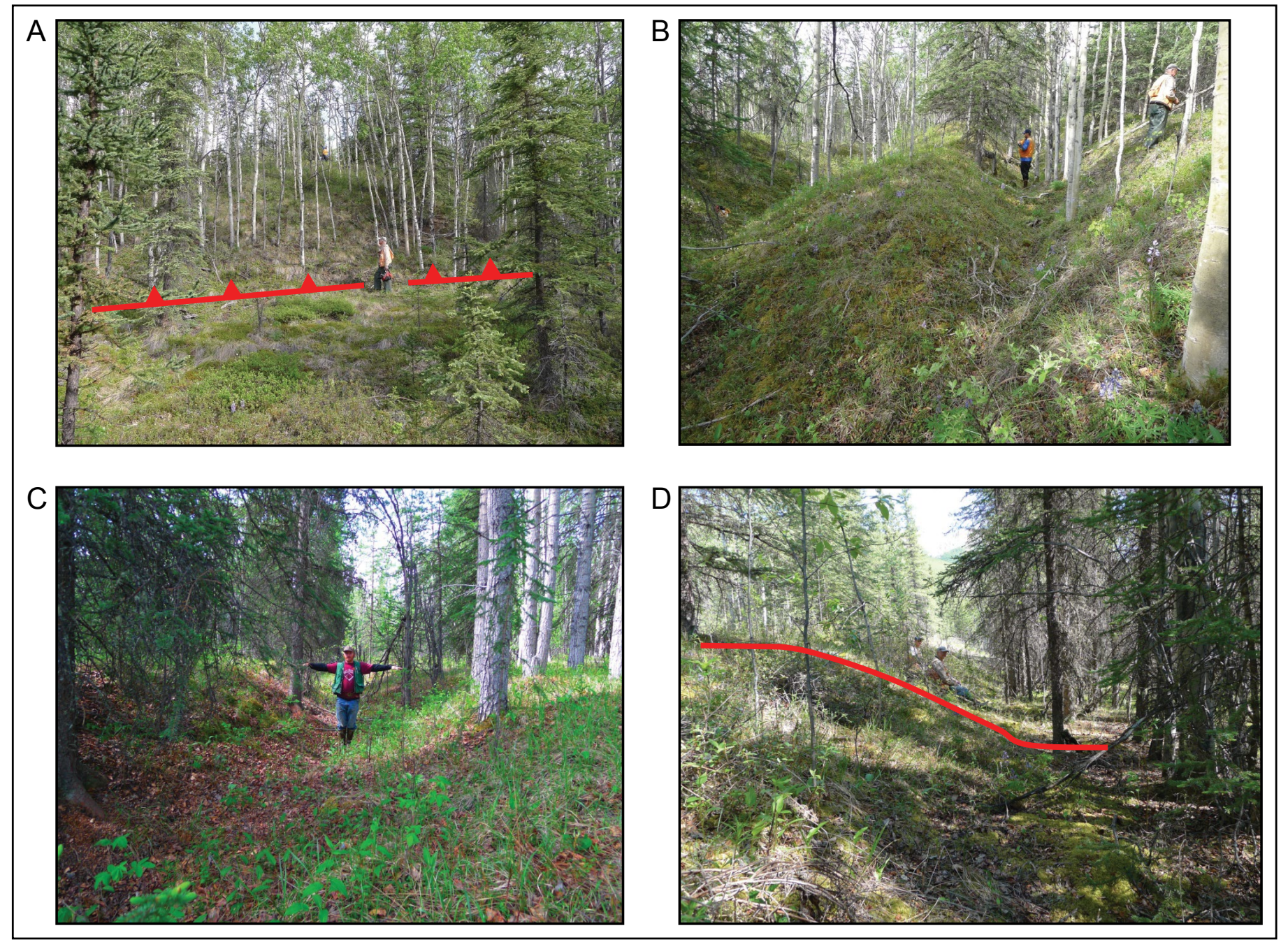

Figure 35. Photographs of scarps along the Park Road fault. A. 12-m-high scarp (fault indicated in red); GPS coordinates $63.725^{\circ} \mathrm{N}$, $148.897^{\circ} \mathrm{W}$. B. Deep hanging wall fissures in Riley Creek-age glacial outwash deposits; GPS coordinates $63.726^{\circ} \mathrm{N}, 148.896^{\circ} \mathrm{W}$. C. Hanging wall fissures in Nenana River fluvial terrace; GPS coordinates $63.729^{\circ} \mathrm{N}, 148.882^{\circ}$ W. D. Scarp (red line) in Holocene fluvial terrace deposits likely modified by Nenana River floods; GPS coordinates $63.730^{\circ} \mathrm{N}, 148.879^{\circ} \mathrm{W}$. 
We infer that a future earthquake could extend between the scarps observed in the Moody Creek drainage and the western limit of well-defined scarps observed on the lidar data within Denali National Park, a distance of approximately $26 \mathrm{~km}$. This fault length results in an estimated maximum earthquake of moment magnitude $\left(\mathrm{M}_{\mathrm{w}}\right) 6.7$ for the Park Road fault.

Several other faults and folds cross the proposed pipeline route in the vicinity of the Park Road fault, including structures at MP 533.38, MP 534.38, and MP 535. We did not observe evidence of Holocene displacement along these structures during our reconnaissance.

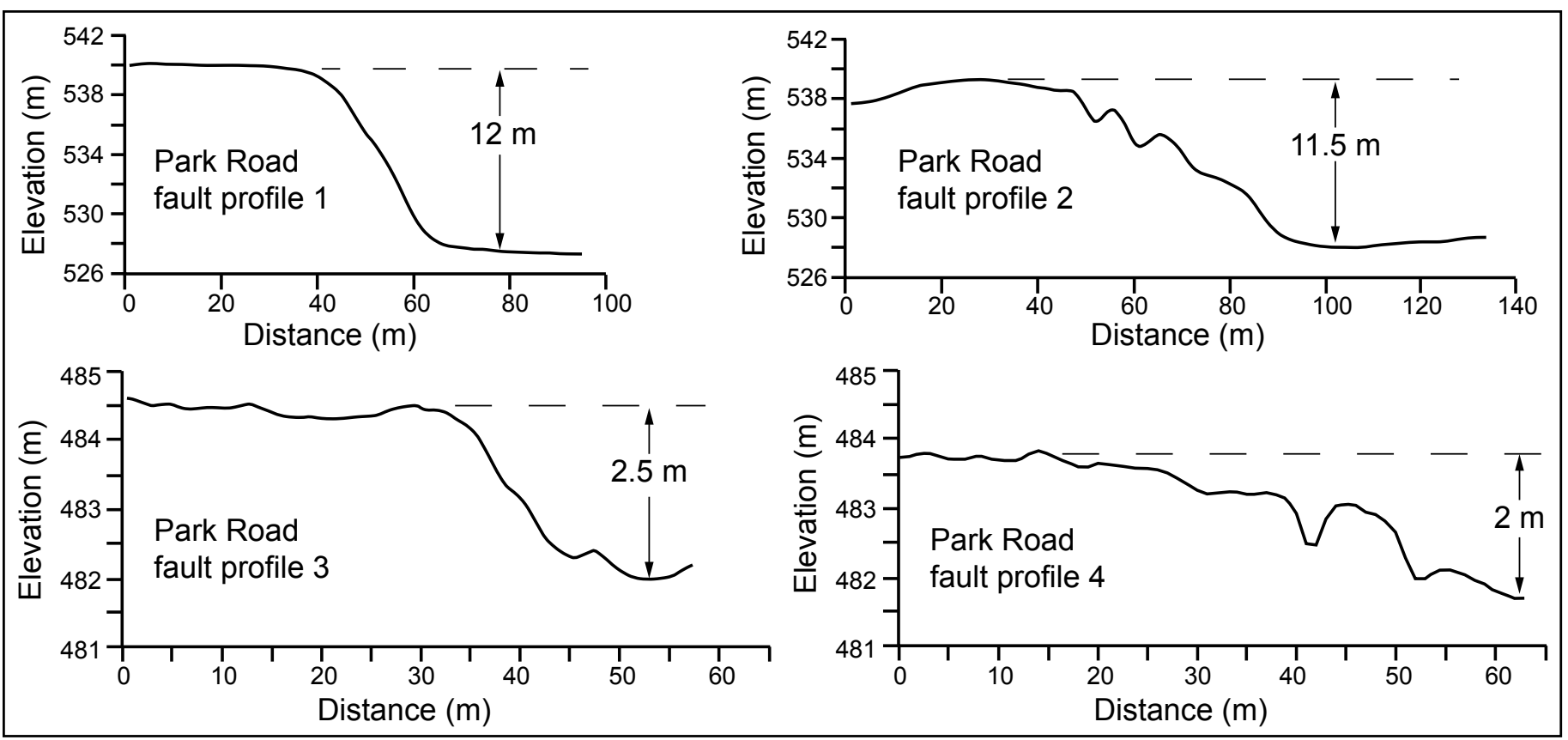

Figure 36. Lidar-generated topographic profiles of segments across the Park Road fault. Profile locations shown in figure 34. 


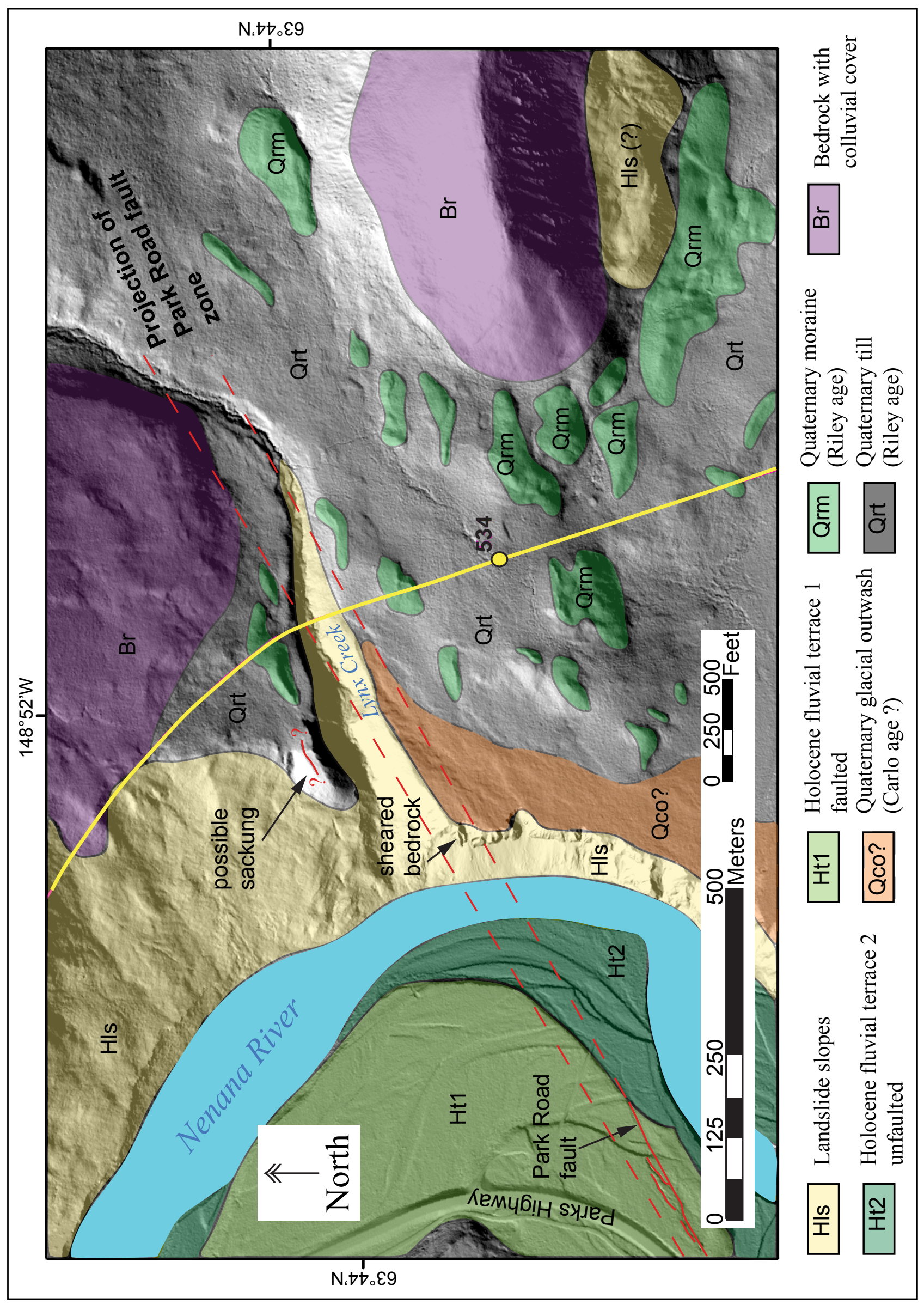

응 z

品离

흥 ชิ

官苋苋

즌 $\frac{1}{\alpha}$

西 $\frac{\pi}{\pi} \frac{0}{0}$

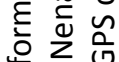

눙

눙

㟧

응 종음

节范学

월

잉

는 응

过

드응

미문

ज़ेّ

نे

ฮั ญั

บ

$x$

을

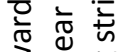

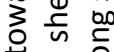

$+\frac{\pi}{5}$

일

茟

ॠ

ॠ

준

论

든 흔

牙

단

웡

导

bo 3

उ

ชั

잉

है

음 응

응 는

$\triangle$

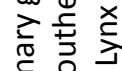

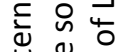

$\stackrel{\square}{\frac{0}{3}}$

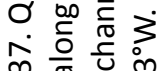

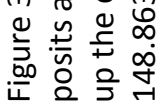




\subsection{Denali Fault}

The Holocene-active right-lateral Denali fault accommodates a component of slip related to the approximately $4.9-5.7 \mathrm{~cm} /$ yr of relative oblique convergence between the Pacific/Yakutat and North American plates. The fault extends for hundreds of kilometers along the arcuate southern margin of the Alaska Range in south-central Alaska (St. Amand, 1957; Grantz, 1966; Plafker and others, 1977) and poses a significant surface fault rupture hazard for the proposed pipeline (fig. 38). Cumulative right-lateral displacement along the fault, based on mapping of the Maclaren terrane, has been estimated to be $400 \mathrm{~km}$ since the early Tertiary (Nokleberg and others, 1985); $300 \mathrm{~km}$ of that motion has occurred in the last $25 \mathrm{Ma}$ (Benowitz and others, 2012). The fault has been divided into three primary sections: western, central, and eastern (fig. 38). The central section extends $\sim 390$ $\mathrm{km}$ from Mt. McKinley on the west to the Totschunda fault on the east and crosses the proposed pipeline route at an orientation of $\sim 259$ degrees. Active tectonic geomorphology is evident along the fault's entire length and the fault is clearly defined and well expressed by scarps and right-lateral offsets in youthful landforms.

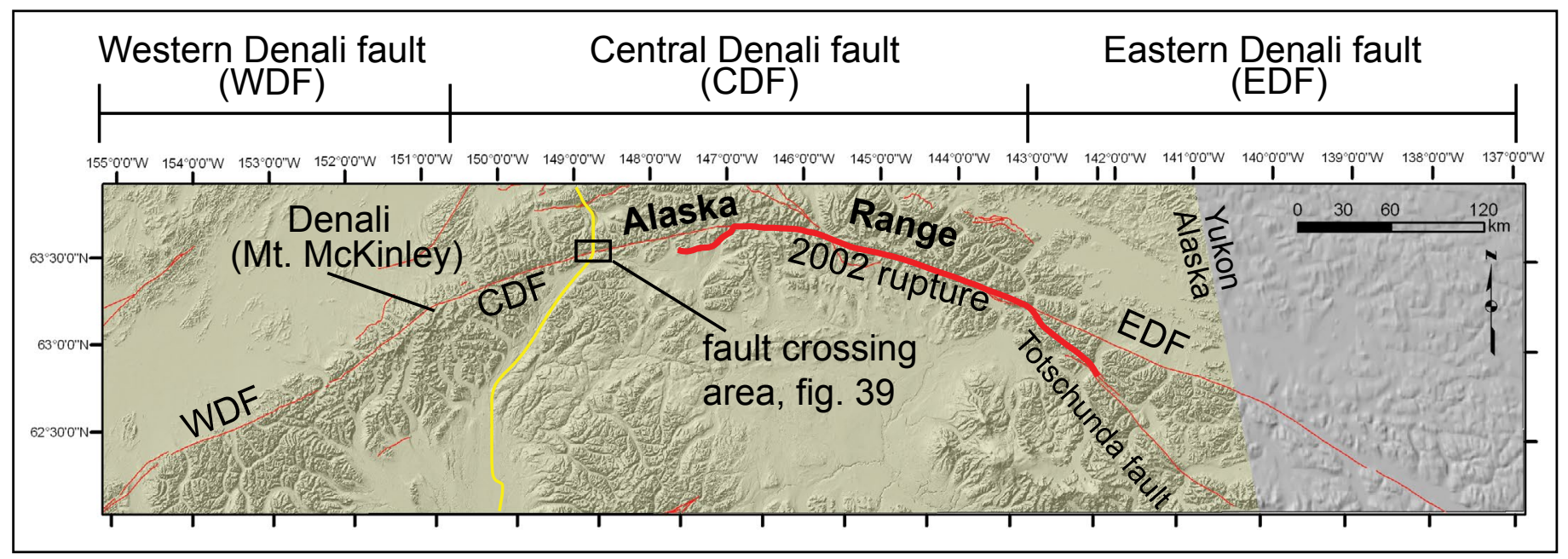

Figure 38. Map of the Alaska Range, showing the extent of the western, central, and eastern sections of the Denali fault. The bold red line is the extent of the 2002 rupture. WDF = western Denali fault; CDF = central Denali fault; EDF = eastern Denali fault. Area of fault crossing and figure 39 shown by black rectangle. Generalized proposed pipeline route shown in yellow.

The eastern part of the central Denali fault section was the source of the $2002 \mathrm{M}_{\mathrm{w}} 7.9$ Denali fault earthquake, which ruptured $340 \mathrm{~km}$ along the Susitna Glacier thrust, Denali fault, and Totschunda fault (Eberhart-Phillips and others, 2003). The rupture was associated with lateral surface displacements averaging between about 2 and $6 \mathrm{~m}$ (maximum $8.8 \mathrm{~m}$ ) and vertical offsets averaging $0.7 \mathrm{~m}$ (maximum $2.7 \mathrm{~m}$ ) (Haeussler and others, 2004). The rupture crossed the Trans-Alaska Pipeline System (TAPS) near the Richardson Highway, where seismic design engineering at the crossing prevented damage to the pipeline. There is no evidence of historic ruptures of the Denali fault west of the 2002 rupture.

Several paleoseismic studies have been conducted along the central Denali fault. Schwartz and others (2003; in review) documented several sites and determined that the 2002 rupture section produced an earthquake sometime between 340 and 590 yr b02 (before 2002) and another between 705 and 1,070 yr b02. At the Delta River Plafker and others (2004) documented four surface-rupturing earthquakes in the last 1,050 years and inferred a recurrence interval of about 350-400 years. Based on mapping and tree-ring dating of damaged trees Carver and others (2004) documented $\sim 2 \mathrm{~m}$ of surface displacement that was attributed to a $\mathrm{M}_{\mathrm{S}}$ 7.2-7.4 earthquake in 1912. West of the 2002 rupture, the central Denali fault produced earthquakes between 100 and $370 \mathrm{yr}$ b02 and between 550 and $680 \mathrm{yr}$ b02 (Schwartz and others, 2003; in review). Trenching efforts across en echelon fissures along the fault on a Nenana River terrace directly east of the Parks Highway indicate the occurrence of at least three paleoearthquakes (Taylor and Bemis, 2012). A similar number of events was described by Koehler and others (2013) in a trench excavated in a displaced alluvial fan $\sim 25 \mathrm{~km}$ east of the Parks Highway near Bruskasna Creek.

Long-term geologic slip rates along the central Denali fault have been evaluated by ${ }^{10} \mathrm{Be}$ surface-exposure dating ${ }^{5}$ of offset deposits and field measurement of the offsets (Matmon and others, 2006; Mériaux and others, 2009). At sites along the 2002 rupture, latest Pleistocene slip rate estimates range between $12.0 \pm 1.8 \mathrm{~mm} / \mathrm{yr}$ (Matmon and others, 2006) and $13.6 \pm 3.8 \mathrm{~mm} /$ yr (Mériaux and others, 2009). West of the 2002 rupture, in the vicinity of the proposed pipeline crossing, slip rate estimates

\footnotetext{
${ }^{{ }^{10} \mathrm{Be}}$ surface-exposure dating is a geochronological technique for estimating the length of time that a rock has been exposed at the earth's surface using cosmogenic radionuclide dating of beryllium-10.
} 
include $6.7 \pm 1.2 \mathrm{~mm} / \mathrm{yr}$ (Mériaux and others, 2009), $9.4 \pm 1.6 \mathrm{~mm} / \mathrm{yr}$ (Matmon and others, 2006), and $7.5 \pm 0.7$ (Koehler and others, 2013). These rates are generally consistent with geodetic measurements of strain accumulation $(6.5-9 \mathrm{~mm} / \mathrm{yr}$; Fletcher, 2002) and indicate a slight westward decrease in slip rate possibly associated with a transfer of stress to faults north of the Alaska Range. Based on the event chronology described above, the central Denali fault in the vicinity of the proposed pipeline route is capable of producing large-displacement earthquakes every 300 to 500 years. Assuming the last earthquake occurred $370 \mathrm{yr}$ b02 and a slip rate of $\sim 9 \mathrm{~mm} / \mathrm{yr}$, the central Denali fault has accumulated $\sim 3.3 \mathrm{~m}$ of strain to be released in a future earthquake.

The location of the central Denali fault near the Parks Highway north of Cantwell has been mapped at a variety of scales and levels of detail by previous workers (fig. 39). Helicopter and field surveys east and west of the Jack-Nenana rivers confluence and proposed pipeline crossing revealed the presence of prominent tectonic geomorphic features providing information on the style and width of deformation. These features indicate that surface rupture is associated with the development of linear sidehill troughs, mole tracks, anastomosing composite scarps that face north and south, and open, left-stepping fissures. The fault is typically associated with a single, well-defined trace where it extends across steep slopes (fig. 40A). In these areas, the width of deformation is confined to several meters and associated with uphill-facing scarps and linear troughs. Where the fault extends across alluvial plains and other unconsolidated deposits, it is expressed as anastomosing scarps and left-stepping, open fissures, pressure ridges, and sag depressions (figs. 40B, C, and D). In these areas, deformation is concentrated along a main strand but distributed across several subsidiary strands in a zone up to $100 \mathrm{~m}$ wide. Measurements of offset rills and gullies indicate that slip during the most recent earthquake was between $\sim 3$ and $5 \mathrm{~m}$, similar to the average displacement in the 2002 earthquake. Although the dominant motion is right-lateral strike-slip, a small component of vertical motion was associated with the most recent rupture. The vertical component was observed along composite scarps at the oversteepened basal part of the slope and is typically between $10 \mathrm{~cm}$ and $1 \mathrm{~m}$.

At the proposed pipeline crossing (MP 556), the fault is not expressed on the surface of the alluvial valley formed at the confluence of the Jack and Nenana rivers (fig. 41); however, the most recently active trace is clearly defined directly to the east and west (fig. 42). The alluvial valley is relatively flat with abundant swamps and is covered by a dense forest. Repeated ground reconnaissance along the projection of the fault did not discover evidence for surface displacement. Similarly, the lidar imagery shows the presence of numerous geomorphically youthful, braided flood channels, indicating that flooding of the alluvial valley has likely buried or removed evidence of the surface trace.

Given the youthful geomorphic environment and lack of a surface trace, the location of the fault at the crossing is uncertain and must be inferred by projecting the strike of the nearest visible location of the active trace toward the proposed pipeline route. Figure 42 shows our mapping of the most recently active trace and possible projections of the fault across the alluvial valley. Because the crossing is closer to the eastern side of the valley (about $500 \mathrm{~m}$ ), we place more confidence in a projection from the east. Based on this projection we infer that the main trace crosses the proposed pipeline route at an orientation of 259 degrees at MP 556 (fig. 43). To connect with the active trace of the fault to the west, the fault could bend or step slightly to the south (dashed red line on figs. 42 and 43). We infer that the most likely location of the fault is within a $\sim 90$-m-wide zone bounded on the north by the northern limit of the fault zone. However, if the fault is associated with a left step to the south, the zone could be even larger. Surface rupture during the 2002 earthquake at the TAPS crossing was associated with a total of $5.8 \mathrm{~m}$ of dextral slip and $1.3 \mathrm{~m}$ of vertical displacement distributed over a zone 1,000 $\mathrm{m}$ wide (Plafker and others, 2004). The 2002 earthquake provides an analog for the style and slip distribution that might be associated with future earthquakes along the Denali fault, including the central Denali fault in the vicinity of the proposed ASAP pipeline crossing.

Based on the uncertainty of the fault location in the Jack and Nenana rivers alluvial valley, we performed ground surveys along a terrace of the Nenana River directly east of the alluvial valley where the fault is well defined. This area represents a possible alternative route in which the location of the fault can be better located. There the fault is confined within a narrow, linear valley ( $\sim 30 \mathrm{~m}$ wide) and is associated with a large shutter ridge (figs. 43 and 44$)$. The most recent surface rupture is associated with fresh $\sim 1$-m-high scarps, left-stepping en echelon fissures, and a small sag depression.

Several additional fault traces have been previously mapped in the vicinity of MP 555. A break in slope west of the Jack River, associated with one of these strands, has characteristics of a glacially scoured slope (rounded morphology); however, logistical constraints prevented us from investigating this feature in the field. It is recommended that further ground reconnaissance be conducted on this feature to verify the absence of recent activity. We did not observe any features indicative of active deformation along any of the other strands.

Future large-magnitude earthquakes along the central Denali fault are expected to have a style and amount of deformation similar to what occurred during the $M_{w} 7.9$ Denali fault earthquake in 2002 . Assuming a future rupture length of $\sim 200 \mathrm{~km}$, the section of the fault between Mt. McKinley and the 2002 rupture, the empirically based maximum earthquake magnitude is estimated to be $M_{w}$ 7.7. An additional estimate of maximum magnitude $\left(M_{\max }\right)$ was determined by Wesson and others (2007) to be $M_{\max }$ 7.9. 


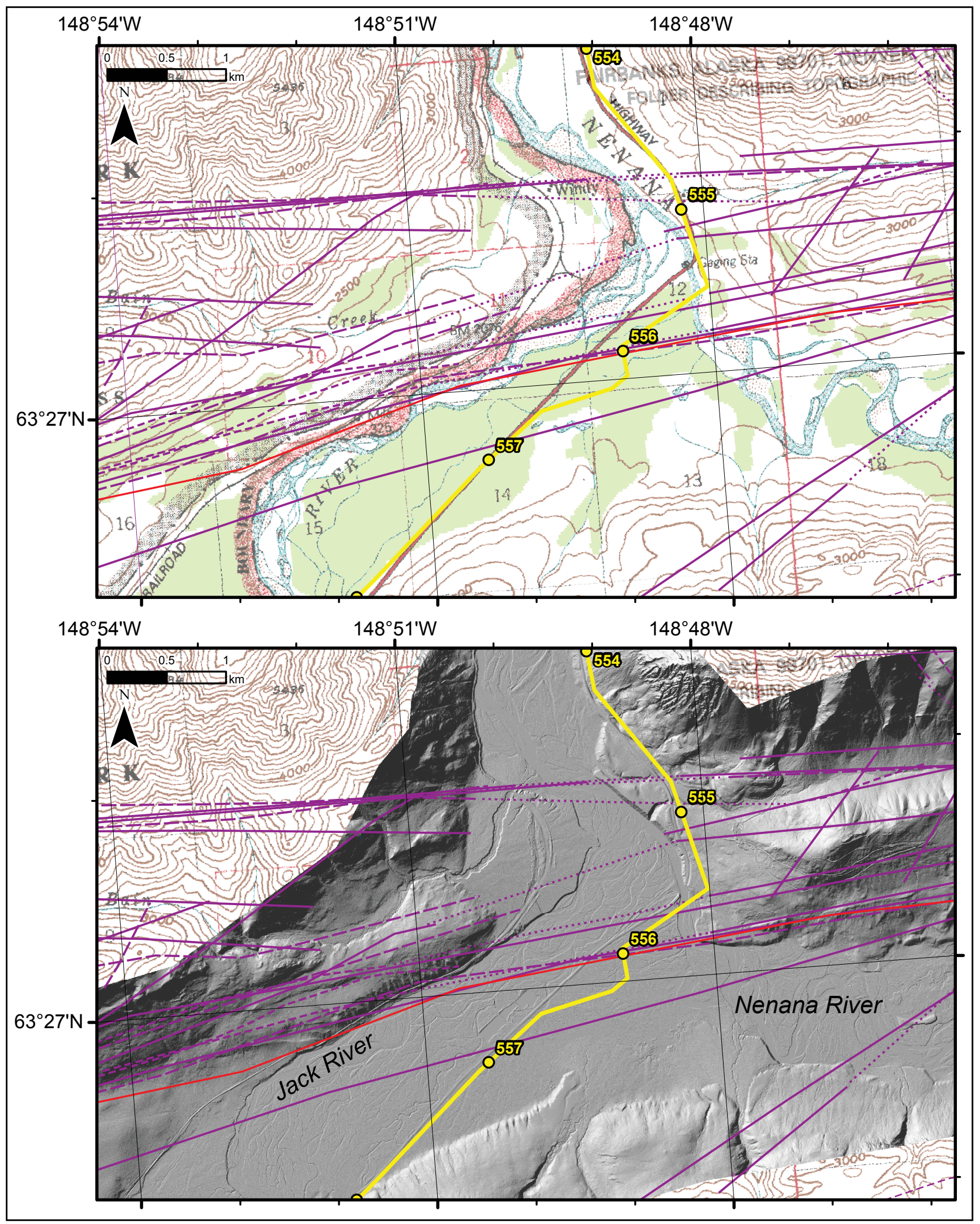

Figure 39. Topographic map (top) and lidar hillshade (bottom), showing the mapped trace of the Denali fault (red line; Koehler and others, 2012a) in the vicinity of the Denali fault crossing. Previously-mapped structures that have not been shown to be active during the Holocene are shown in purple; see Appendix A for references. Although we did not observe evidence for activity along these features in our helicopter reconnaissance, they were not investigated on the ground. Mileages refer to proposed pipeline route, shown by yellow line. For reference, MP 556 is located at GPS coordinates $63.452^{\circ} \mathrm{N}, 148.815^{\circ} \mathrm{W}$. 


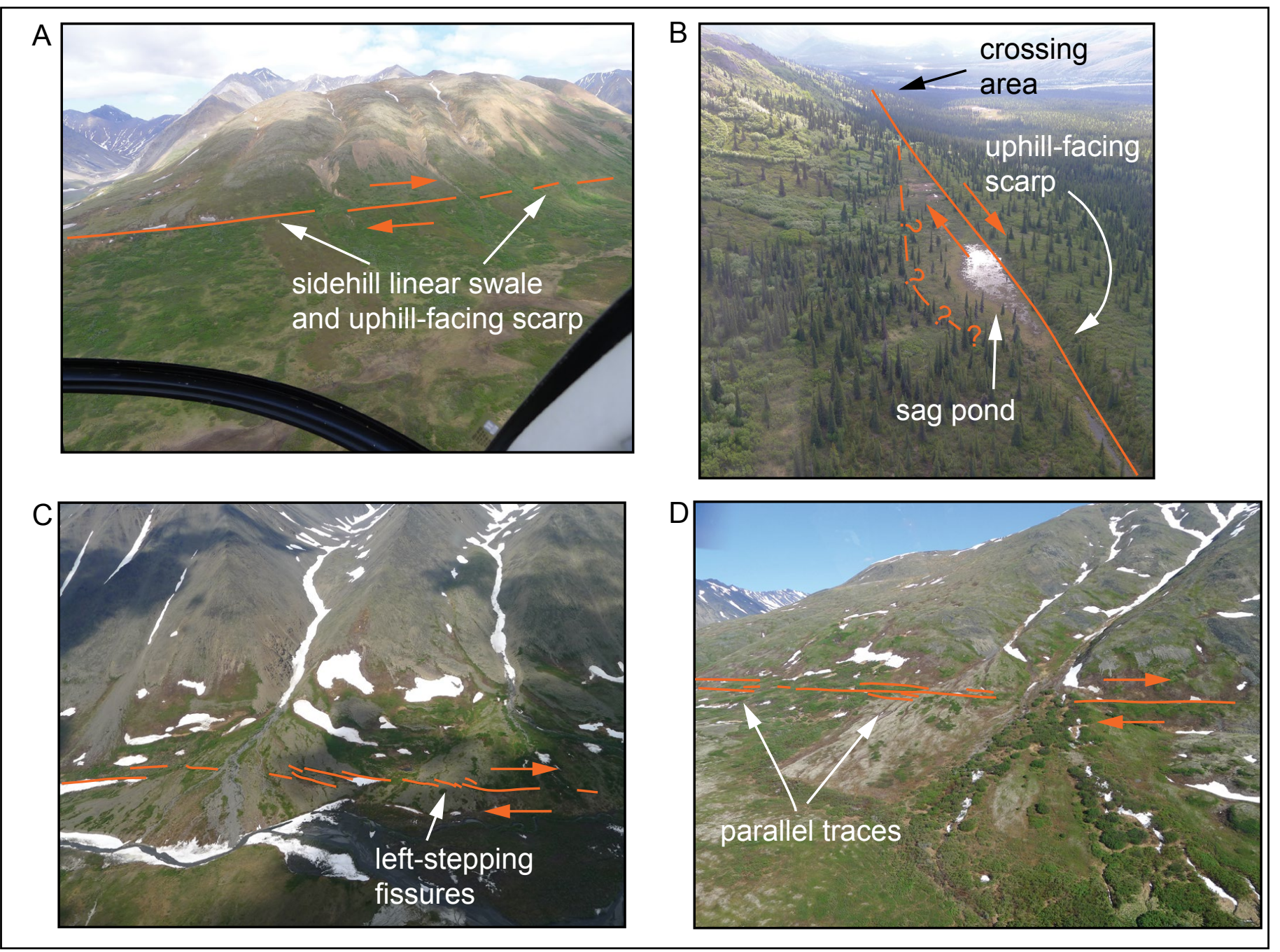

Figure 40. Photographs illustrating surface rupture patterns along the Denali fault. A. Simple straight trace where the fault extends across a steep bedrock slope west of the crossing. Photograph taken from helicopter looking north from GPS coordinates $63.404^{\circ} \mathrm{N}$, $149.261^{\circ}$ W. B. Sag depression directly west of crossing. Helicopter photograph looking east from GPS coordinates $63.443^{\circ} \mathrm{N}$, $149.958^{\circ} \mathrm{W}$. C and D show the wide zone of deformation associated with left-stepping en echelon fissures and parallel traces where

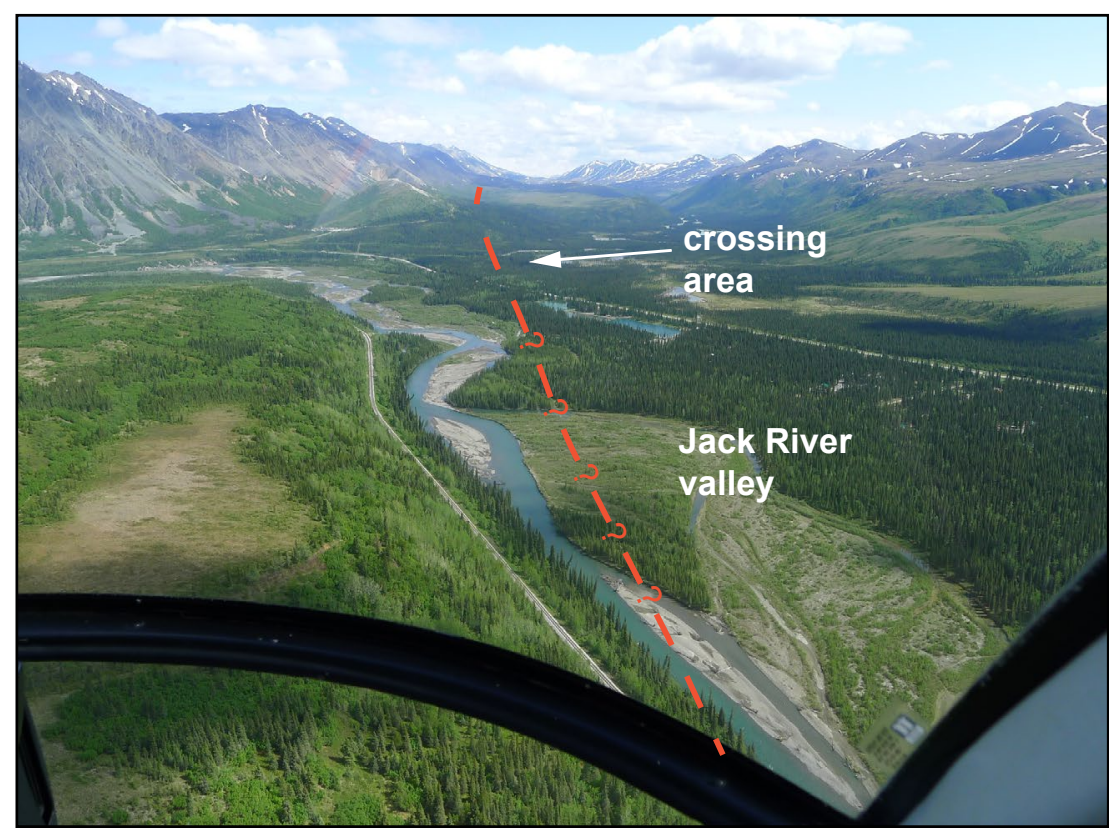
the fault crosses unconsolidated alluvium and colluvium east of the crossing. Both photographs taken from helicopter looking north. GPS coordinates for photograph $\mathrm{C}$ are $63.485^{\circ} \mathrm{N}, 148.083^{\circ} \mathrm{W}$; GPS coordinates for photograph D are $63.474^{\circ} \mathrm{N}$, $148.328^{\circ} \mathrm{W}$.

Figure 41. Oblique air photo of the projection of the Denali fault across the forested Jack River alluvial valley in the vicinity of the proposed ASAP pipeline route. View is to the east; photograph taken from helicopter from GPS coordinates $63.447^{\circ} \mathrm{N}, 148.871^{\circ} \mathrm{W}$. 


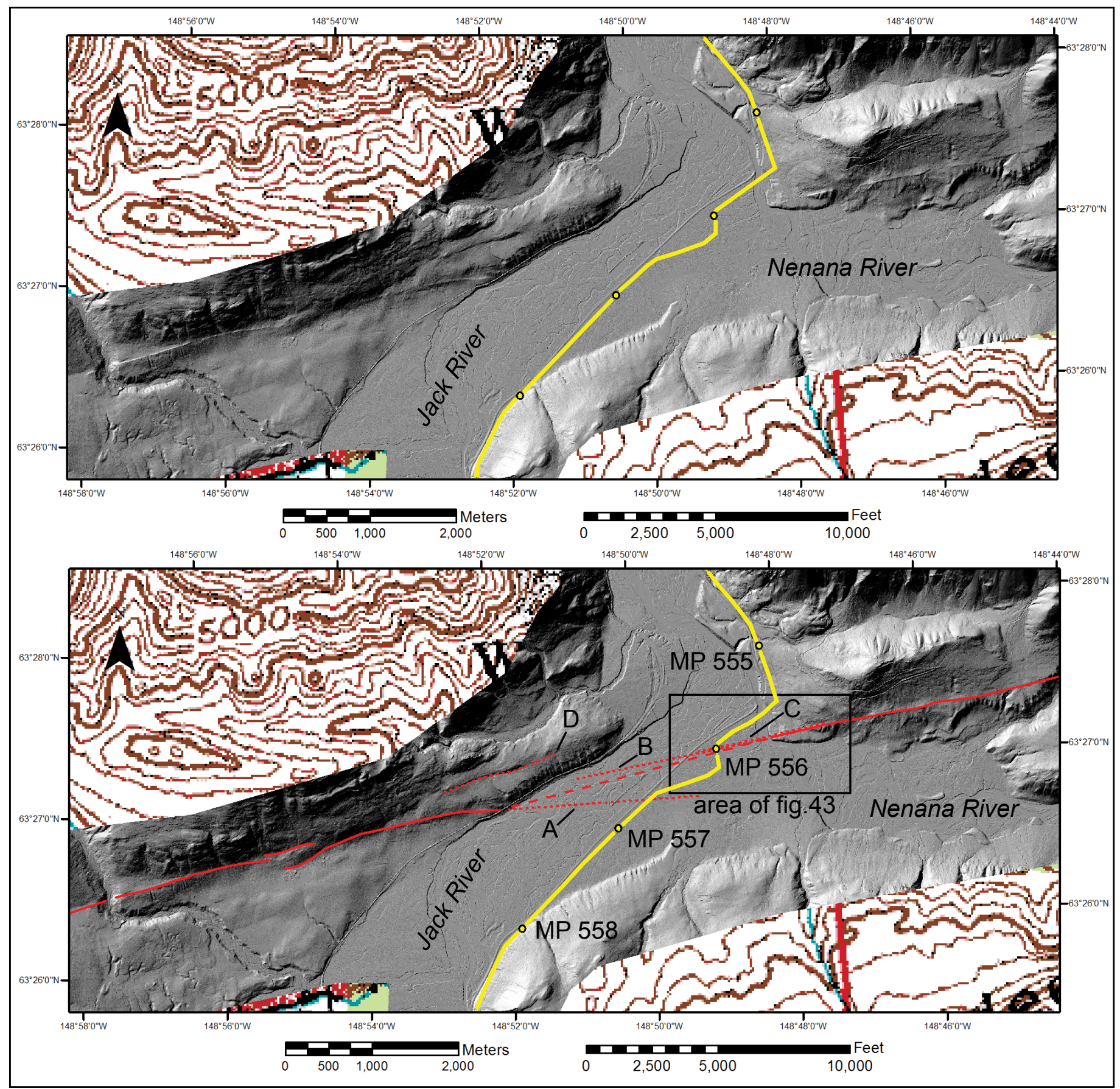

Figure 42. Lidar hillshade image of the Denali fault at the confluence of the Jack and Nenana rivers. Proposed pipeline route shown by yellow line. Uninterpreted image shown at top. Traces of the Denali fault mapped in this project are shown in red in bottom image. Solid lines are well-located fault traces. Dashed line is a straight line connection of the most recent surface rupture from either side of the alluvial valley. Dotted lines are: A. projection of the most recent surface rupture from the west; B. projection of the most recent surface rupture from the east; C. projection of the northern limit of the fault zone from the east; and D. possible older fault trace or glacial scour lineament. Mileposts shown in black next to yellow circles on the route. For reference MP 556 is located at GPS coordinates $63.452^{\circ} \mathrm{N}, 148.815^{\circ} \mathrm{W}$. 


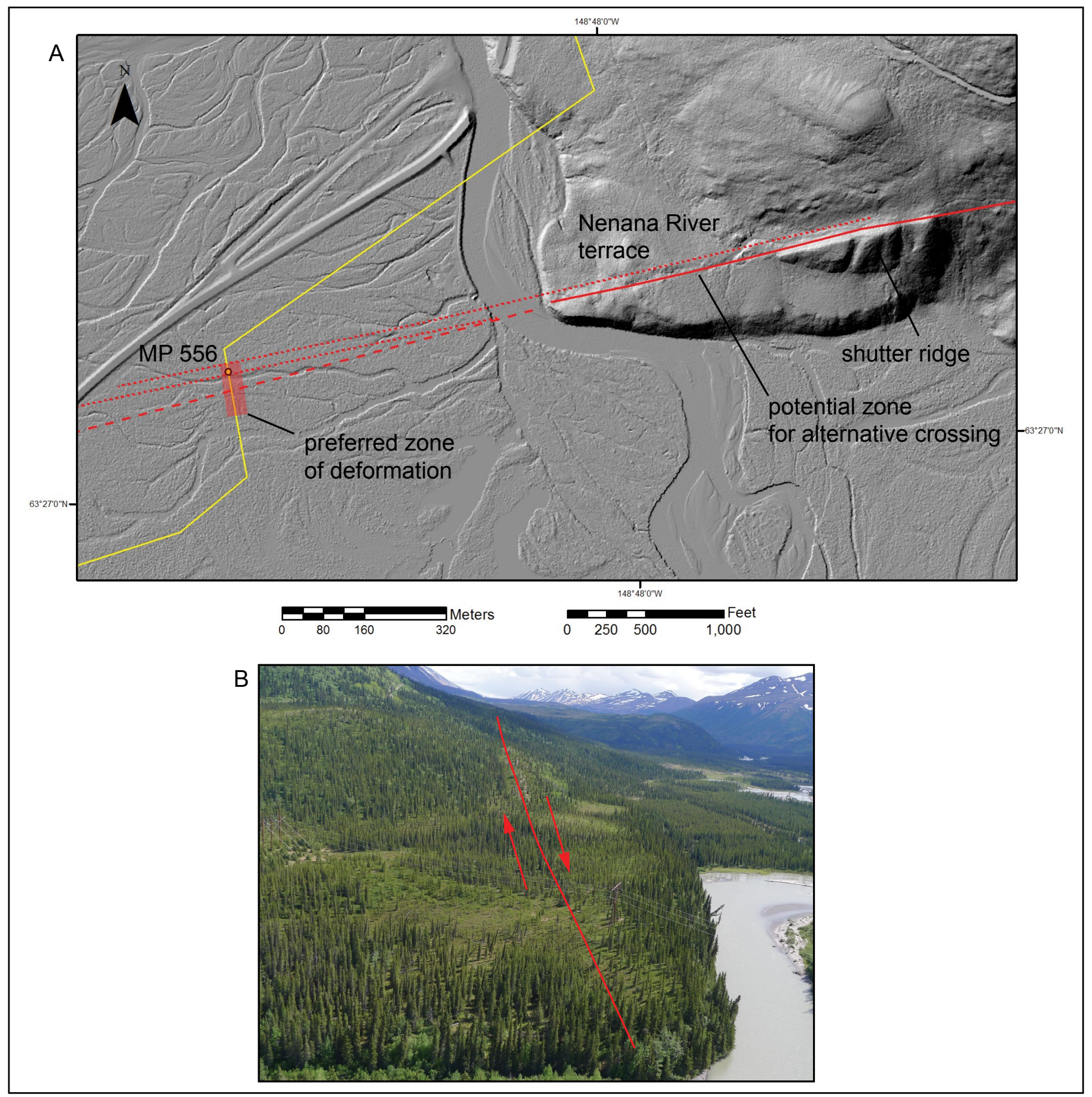

Figure 43. A. Lidar hillshade image zoomed in to the Denali fault crossing, showing the preferred interpretation of the width of deformation marked by red-shaded rectangle. Definitions for dashed and dotted lines are described in caption for figure 42 . For reference MP 556 is located at GPS coordinates $63.452^{\circ} \mathrm{N}, 148.815^{\circ} \mathrm{W}$. B. Oblique photo showing possible alternative crossing on Nenana River terrace east of the river. View to east taken from helicopter from GPS coordinates $63.452^{\circ} \mathrm{N}, 148.807^{\circ} \mathrm{W}$. 


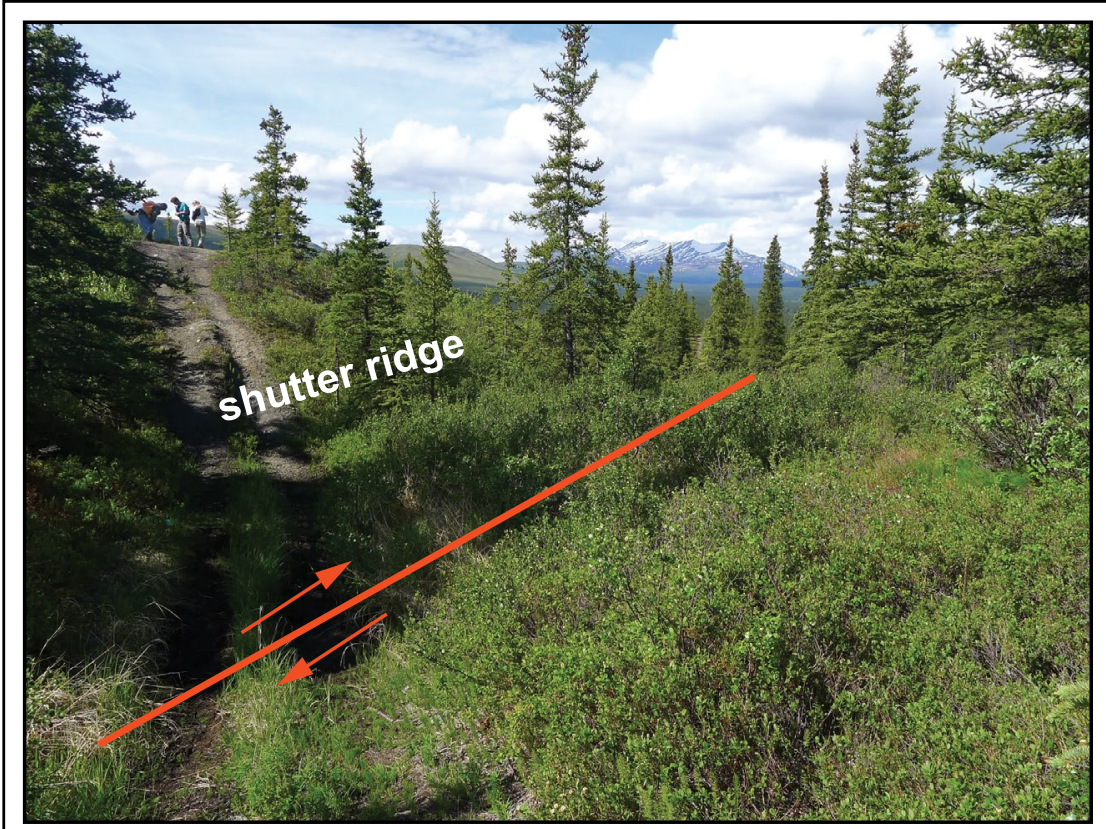

Figure 44. Photographs of the Denali fault directly east of the Nenana River. Bedrock shutter ridge and narrow fault valley (top, GPS coordinates $63.454^{\circ} \mathrm{N}, 148.787^{\circ} \mathrm{W}$ ) and $\sim 1-\mathrm{m}$-high north-facing scarp (bottom, GPS coordinates $63.453^{\circ} \mathrm{N}$, $\left.148.798^{\circ} \mathrm{W}\right)$. Geologists for scale.

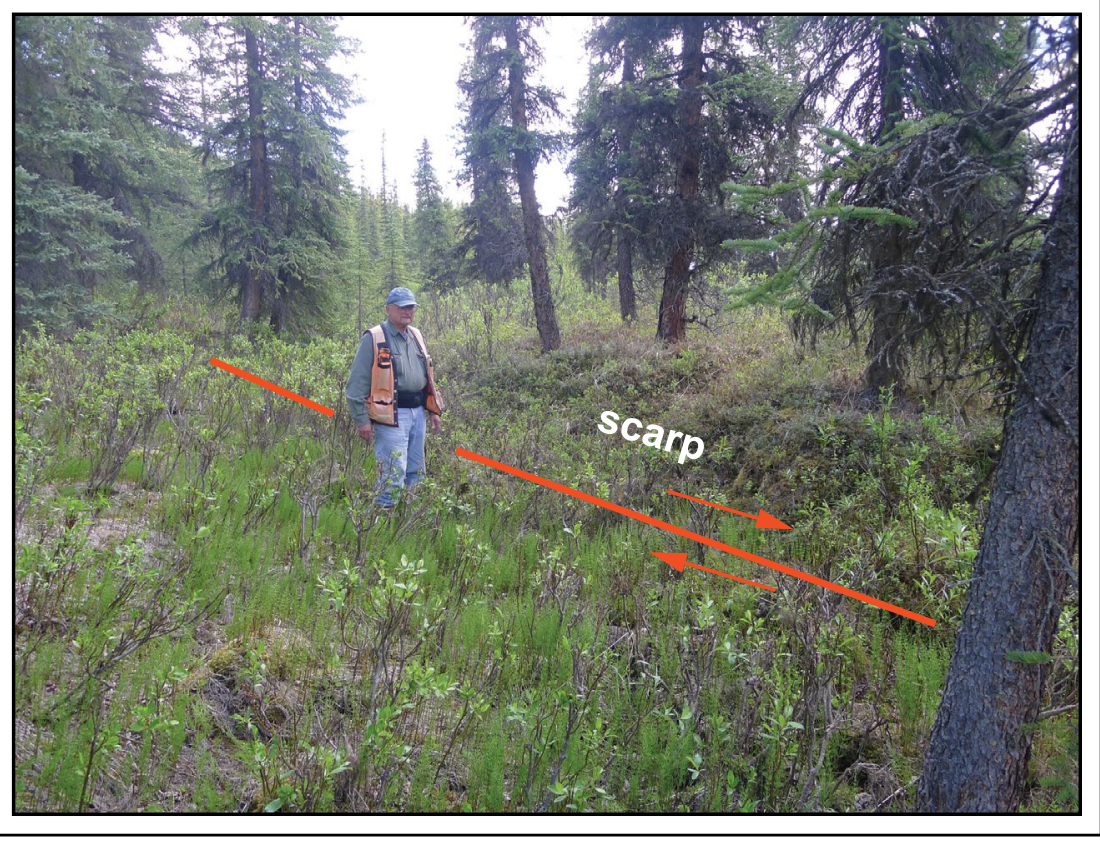

\subsection{Castle Mountain Fault}

The Castle Mountain fault extends from the southern front of the Talkeetna Mountains on the east to Mount Susitna on the west, and represents the structural boundary between the Cook Inlet forearc basin on the south and the Susitna basin on the north (fig. 45). The fault has a regional orientation of 240 degrees and poses a significant surface fault rupture hazard to the proposed pipeline. Interpretation of geophysical data from the Susitna lowland indicates Cenozoic, north-side-up, dip-slip movement of at least $0.5 \mathrm{~km}$ and development of a 4-km-wide anticline (Kelly, 1963; Haeussler and others, 2000). Bedrock mapping to the east indicates post-Paleocene lateral slip of $\sim 14 \mathrm{~km}$ (Fuchs, 1980; Kelly, 1963). Evidence for active deformation includes a well-defined $\sim 60-\mathrm{km}$-long topographic scarp that is readily identifiable by distinct vegetation lineaments in the Susitna lowland (fig. 46) and the occurrence of two moderate historic earthquakes in $1984\left(\mathrm{M}_{\mathrm{w}}\right.$ 5.7, Lahr and others, 1986) and 1996 (M 4.6) along the base of the Talkeetna Mountains (fig. 45).

Previous paleoseismic investigations report conflicting results regarding the style and rate of Quaternary deformation. Dettermann and others (1974) dated a buried soil exposed in a trench excavated across a 2.1-m-high scarp east of the Little Susitna 


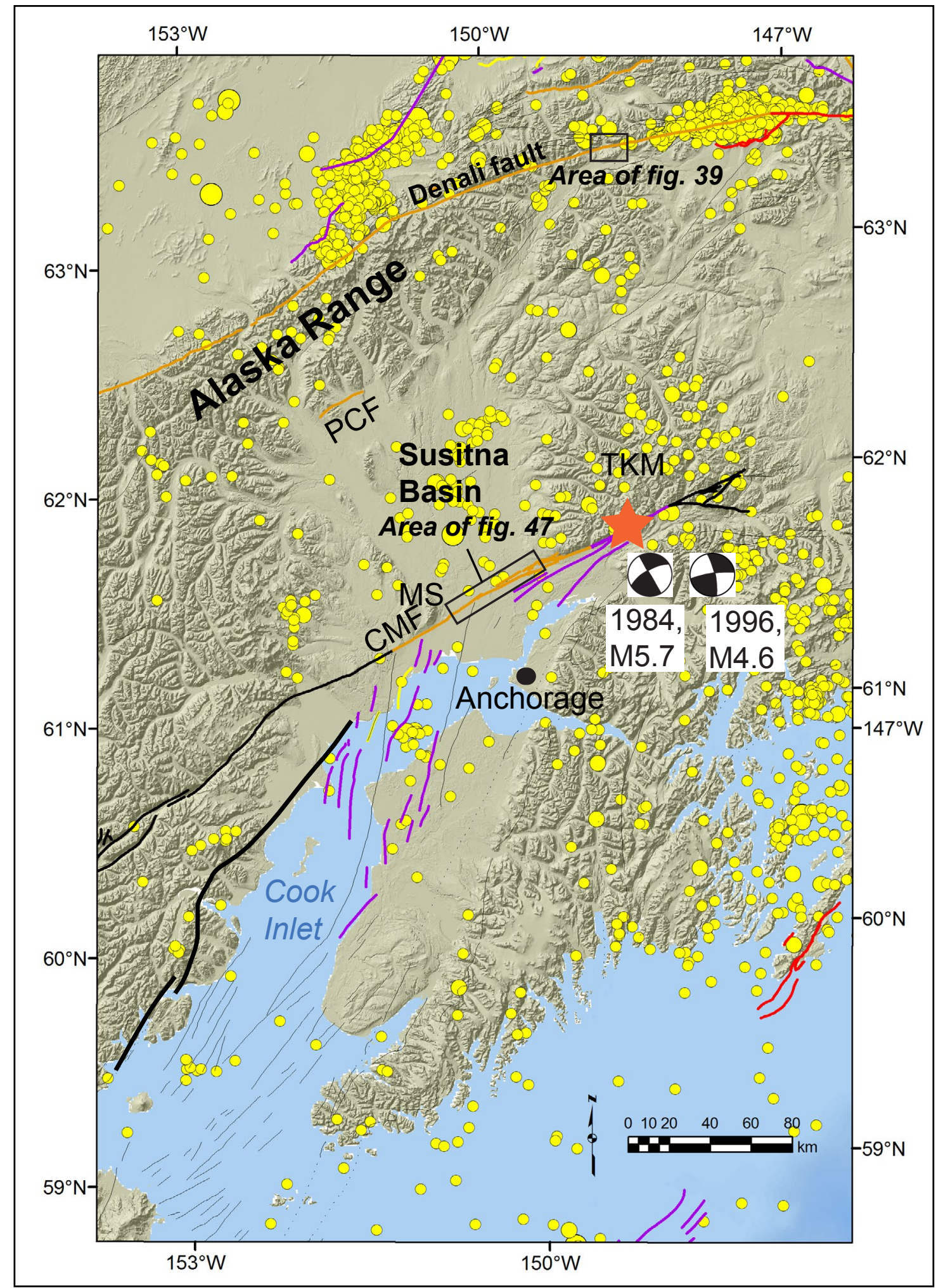

Figure 45. Shaded relief map of south-central Alaska, showing the location of the Castle Mountain (CMF) and Denali faults. Fault colors indicate relative activity including black (suspicious), purple (Quaternary), yellow (latest Quaternary), orange (latest Pleistocene to Holocene), and red (historic). Thin black lines indicate other poorly studied faults in Cook Inlet. Location of historic earthquakes on the eastern Castle Mountain fault shown by red star. Areas of figures 39 and 47 outlined by black rectangles. Yellow circles show shallow crustal seismicity of M >3 from 1980 through 2011. Black and white "beach balls" signify sense of motion for historic earthquakes. MS = Mount Susitna; TKM = Talkeetna Mountains; PCF = Pass Creek Fault. Modified from Koehler and others, 2012a. 
River and imply a $1,860 \pm 250 \mathrm{yr}$ BP age for the most recent event; however, the number of events was not reported. At this locality, the fault dips 75 degrees north. Detterman and others (1974) also suggest possible right-lateral displacements of 3.6 to $7 \mathrm{~m}$, but during our assessment of lidar data we were unable to verify these observations and do not consider them reliable. Trenching studies by Haeussler and others (2002) suggest thrust motion along the fault and the occurrence of four late Holocene earthquakes in the last 2,700 years. A late Pleistocene-Holocene right-lateral slip rate of $2-3 \mathrm{~mm} / \mathrm{yr}$ was estimated by Willis and others (2007) based on lateral offset of $36 \mathrm{~m}$ measured on an inferred channel margin. Based on our field and lidar evaluations, including a visit to the Willis and others (2007) site, offsets of this amount do not occur anywhere along the fault between Houston and the Susitna River (see discussion below); thus we infer that the channel margin that they used to estimate a slip rate is not a fault offset and that the rate they report is unreliable.

Surficial-geologic mapping was performed along $\sim 40 \mathrm{~km}$ of the fault trace in the Susitna lowland to independently evaluate the results of previous paleoseismic investigations and to better characterize faulted deposits and fault rupture parameters. The mapping indicates that the fault is characterized by three relatively straight, well-expressed, and clearly defined traces that gradually change strike from east to west from 242 to 236 degrees. These traces, which trend $\sim 270$ degrees, are separated by two $\sim 1-\mathrm{km}$-wide bends, including one where the Little Susitna River crosses the fault and another in the vicinity of Fish Creek (fig. 47). In some areas, the scarp is confined to a narrow zone less than several meters wide. However, much of the fault trace is characterized by wide zones $(25-150 \mathrm{~m}$ ) of left-stepping, en echelon surface scarps oblique to the trace of the fault, and left-stepping grabens up to $400 \mathrm{~m}$ north of the scarp. In the vicinity of the proposed pipeline crossing, at about MP 716.35, the fault trace lacks a well-defined scarp and crosses the proposed pipeline route at an orientation of 240 degrees (fig. 48). Several left-stepping scarps occur $\sim 90 \mathrm{~m}$ east of the crossing. There the width of the zone of en echelon scarps is about $40 \mathrm{~m}$. West of the crossing the fault is clearly delineated by a vegetation lineament. In this area a $2.8 \mathrm{-km}-$ long topographic profile shows a broad, 1,500-m-wide anticline associated with a gentle south-facing slope north of the fault, indicating that the fault might have a very shallow dip and be blind at the crossing (fig. 49).

Offset late Elmendorf (14-15 ka) glacial and Holocene deposits including glacial drift, sandy fan deltas, outwash plains, grounding-line moraines, stream terraces, and oxbow lakes (fig. 47) (Koehler and others, 2012b) provide observations that bear on the style and amount of displacement. Vertical displacements across these deposits vary in height from $\sim 0.5$ to $5 \mathrm{~m}$,

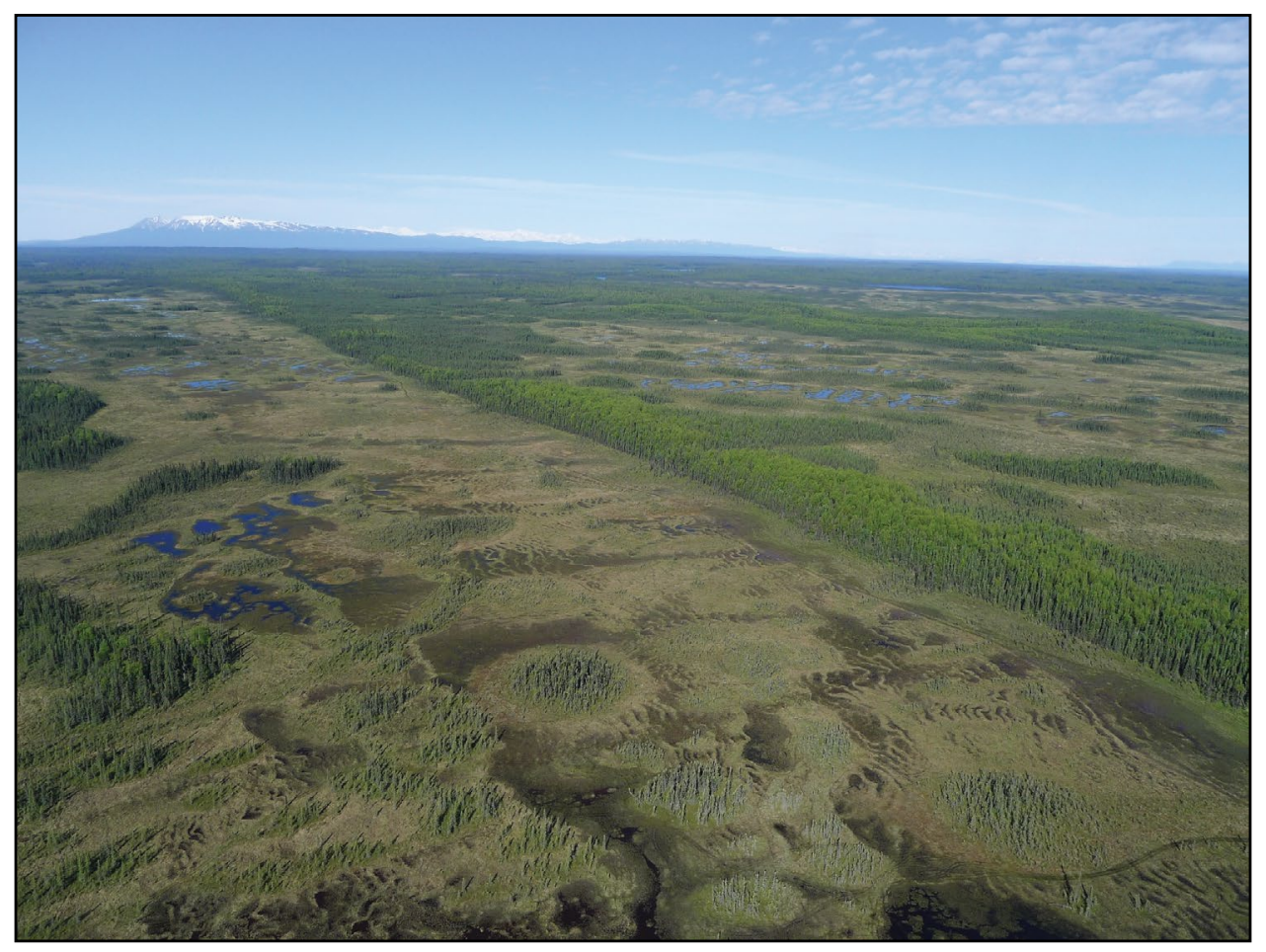

Figure 46. View to west of the Castle Mountain fault. The fault scarp is clearly expressed as a distinct vegetation lineament characterized by large, deciduous trees growing along the uplifted north side of the fault and stunted black spruce growing south of the fault. Mount Susitna is in the background. Photograph taken from helicopter at approximate GPS coordinates $61.53^{\circ} \mathrm{N}, 150.282^{\circ} \mathrm{W}$. 


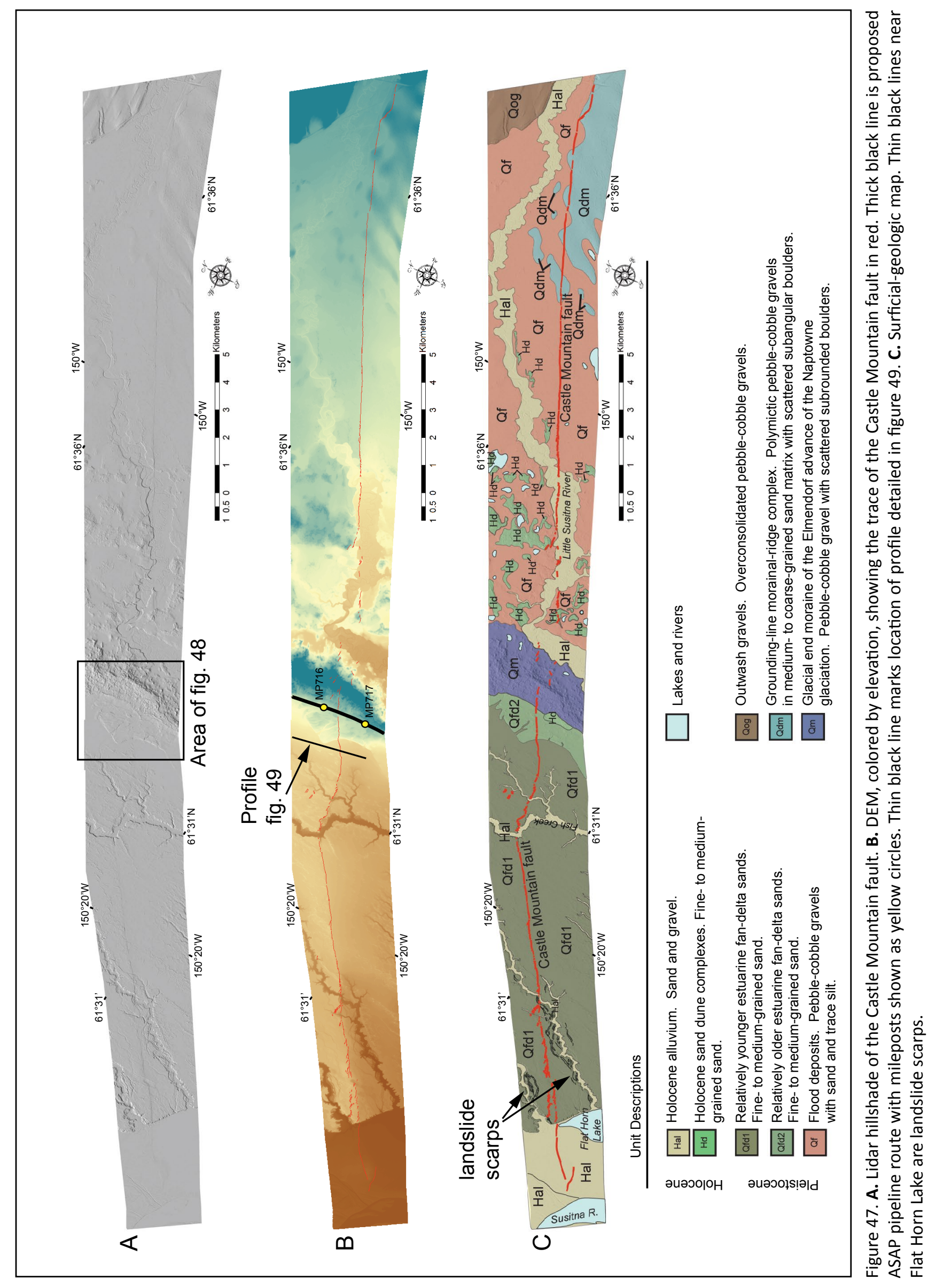




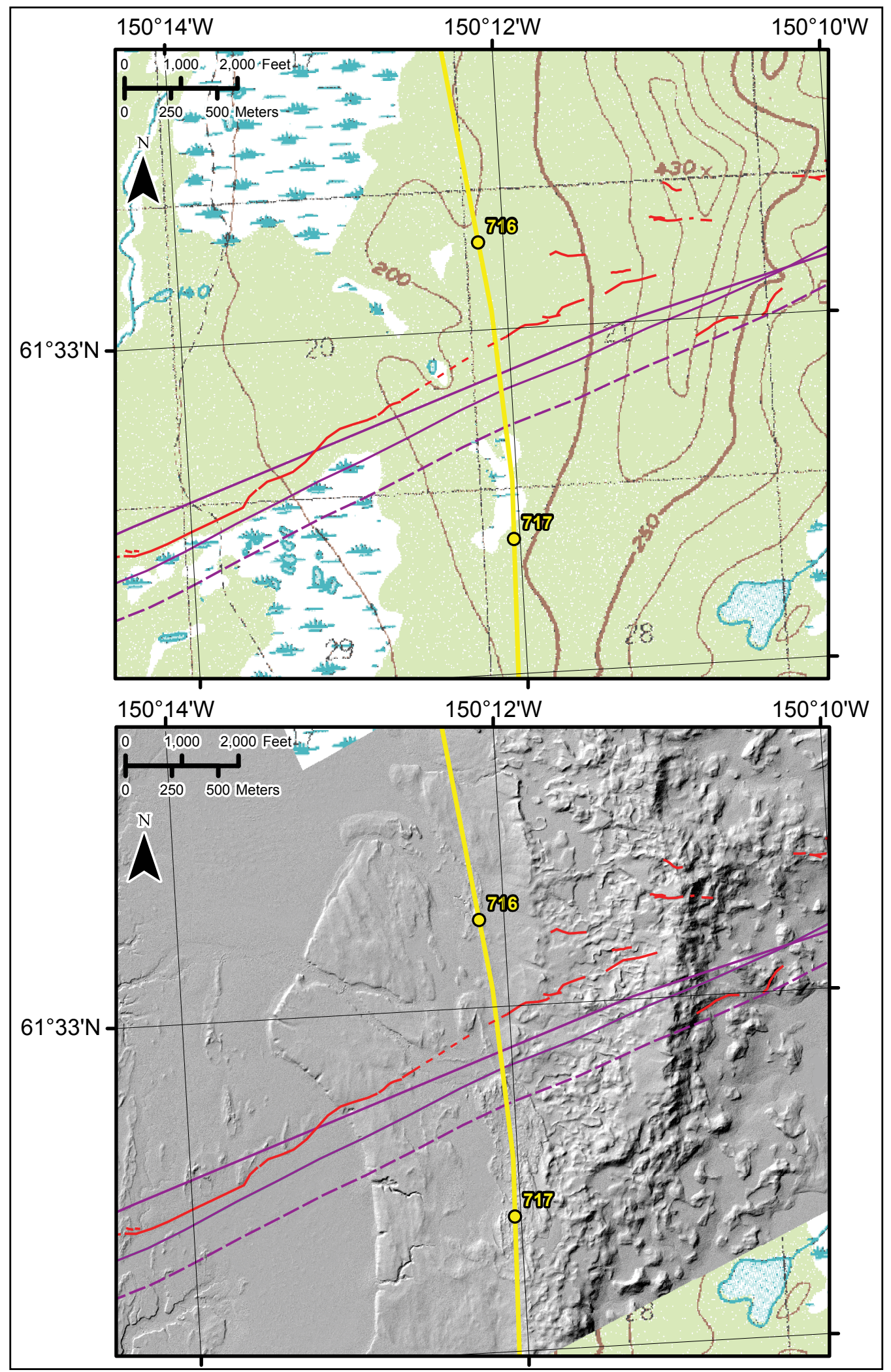

Figure 48. Topographic map (top) and lidar hillshade (bottom), showing the mapped trace of the Castle Mountain fault (red line, this study) in the vicinity of the proposed pipeline crossing. Proposed pipeline route shown by yellow line. Mapping for this project is based on lidar interpretation and field mapping and is more accurate than previous depictions of the fault based on desktop studies by others (purple lines). See Appendix A for references. 


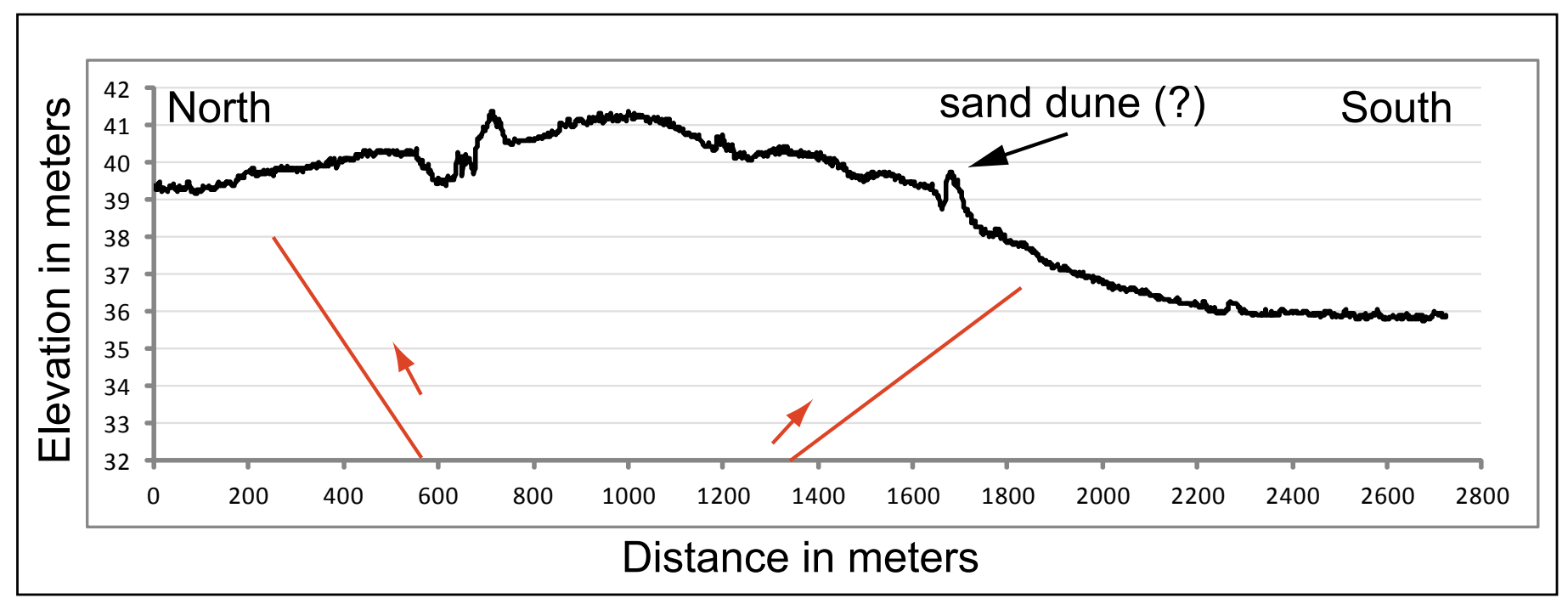

Figure 49. Topographic profile directly west of proposed pipeline crossing, showing originally flat sand plain surface at $36 \mathrm{~m}$ elevation that is warped into an anticline across the fault. Inferred faults shown are schematic. Location of profile shown on figure 47.

and are likely the result of two or more earthquakes (fig. 50). Larger scarps are typically composites of several overlapping smaller scarps. Numerous abandoned channels, stabilized sand dunes, and terrace margins oriented orthogonal to the scarp are vertically offset, and show little lateral displacement (fig. 51). It is possible that glacial advances removed all evidence of late Pleistocene lateral displacement and that the Holocene features present on the Susitna lowland are too young and subtle to preserve evidence of lateral slip. However, the evidence developed in this investigation strongly suggests that the dominant sense of displacement in the Holocene has been reverse. We acknowledge that lateral displacements of up to a meter might not be recognizable due to the curvilinear nature of geomorphic features crossing the fault.

Logistical constraints prevented excavation of a trench at the proposed pipeline crossing; therefore two trenches (CMF-T-1 and CMF-T-2) were excavated approximately $20 \mathrm{~km}$ east of the crossing in the Little Susitna River valley (fig. 52). The purpose of the trenching was to assess the number of displacement events and better characterize rupture parameters, including the dip of the fault in the shallow subsurface. The trenches were excavated across a $\sim 1-\mathrm{m}$-high south-facing scarp that cuts flood deposits inset into a late Elmendorf (14-15 ka) grounding-line moraine. Both trenches exposed interbedded layers of well-sorted fluvial sand and poorly sorted pebble-cobble gravels that postdate the grounding-line moraine (fig. 53). These strata are cut by a 1- to 2-m-wide fault zone. Folded strata north of the fault zone indicate that the total area of deformation is distributed over a 4-m-wide zone. Stratigraphic and structural relations exposed in the trenches provide evidence for at least two earthquakes in latest Pleistocene/Holocene time (figs. 54 and 55). The most recent event is associated with several anastomosing subvertical fault traces that break the surface and form the scarp. A small graben or depression is present south of the main scarp and is bounded by a second set of faults that dip 70 degrees north. These faults, buried by a subtle soil and overbank sand deposit (Unit 2), provide evidence for the penultimate earthquake. Radiometric analyses on an unidentified vitrified seed and a charred Arctostaphylos seed (Samples RDK-CMF-RC1 and RDK-CMF-RC2, fig. 54, Appendix B) indicate that the penultimate earthquake occurred prior to $\sim 12,000$ cal yr. B.P. Drag folding, discrete vertical offsets, stratigraphic juxtapositions, and thickness changes across individual fault traces are consistent with both vertical and lateral deformation. Although facies and thickness changes of the thin fluvial deposits make correlation of stratigraphic units difficult, the gross stratigraphic packages are generally consistent across the fault zone, suggesting that the lateral component of slip is small.

Based on the mapping of scarp and fault zone morphology, rupture trace geometry, and continuity of geomorphic features across the fault, earthquakes along the Castle Mountain fault are best characterized by oblique reverse faulting above a north-dipping fault. The grabens north of the fault are the product of folding and extension (bending moment deformation) in the crest of an anticline developing in the hanging wall of a reverse fault. The left-stepping en echelon pattern of scarps permits a small oblique component of right-lateral slip. These observations on the style of deformation differ from the view of Willis and others (2007) in terms of the amount of lateral displacement. The previously reported slip rate of $3 \mathrm{~mm} / \mathrm{yr}$ is likely too fast; the actual rate might be closer to the long-term bedrock slip rate of $<0.3 \mathrm{~mm} / \mathrm{yr}$.

Although the fault is not expressed at the surface at the pipeline route crossing, the profiles, mapping, and trenching suggest that future earthquakes along the Castle Mountain fault will manifest at the surface as several meters of north-side-up folding distributed across a 1,500-m-wide zone north of the pipeline route crossing and discrete surface ruptures of $0.5-1 \mathrm{~m}$ on several 


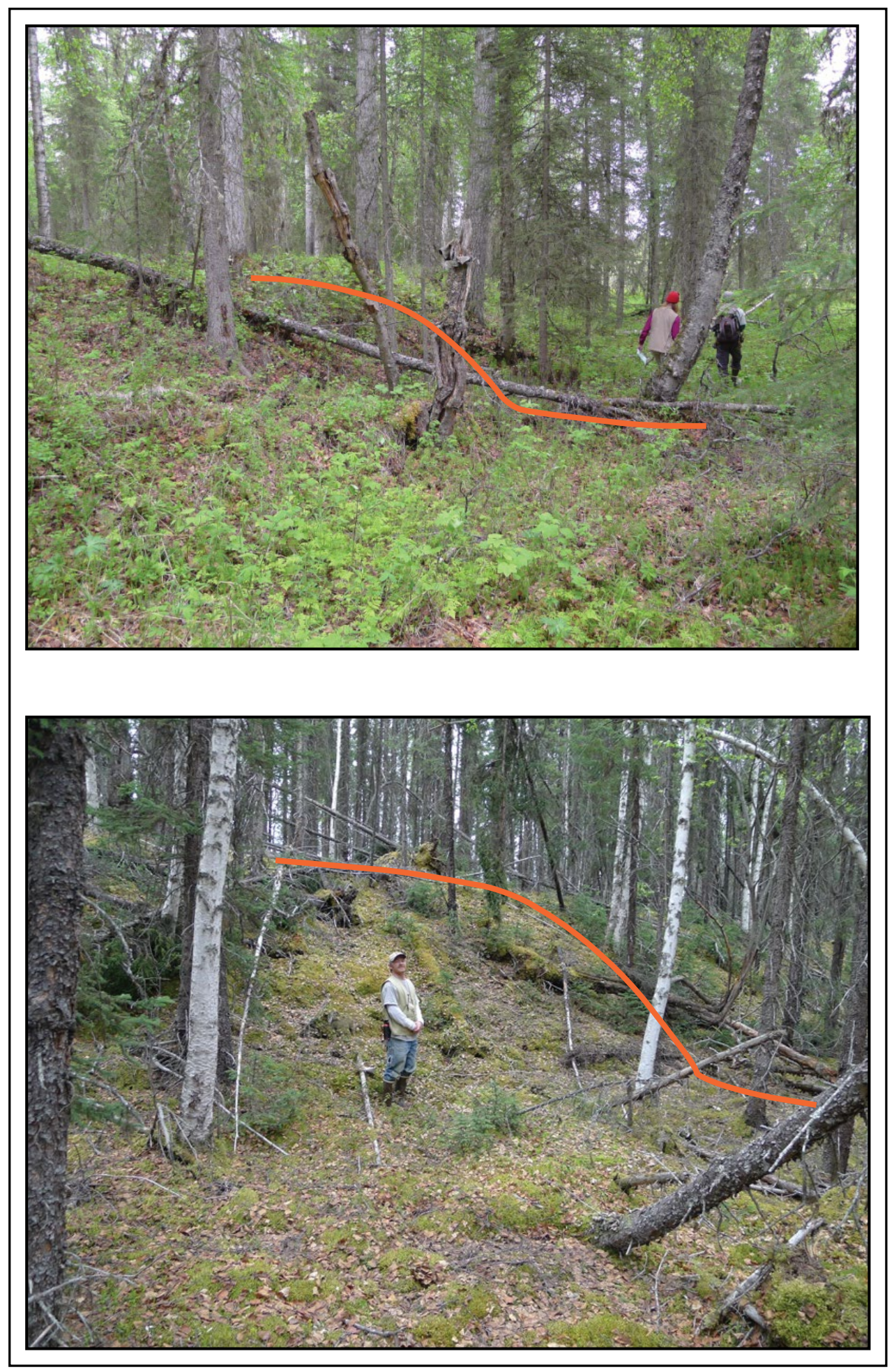

Figure 50. Photos showing typical scarps along the Castle Mountain fault, with vertical displacement on the north side. Scarp profile indicated by red line. GPS coordinates for top photo: $61.573^{\circ} \mathrm{N}, 150.061^{\circ} \mathrm{W}$. GPS coordinates for bottom photo: $61.577^{\circ} \mathrm{N}, 150.044^{\circ} \mathrm{W}$. 
en echelon faults within a $\sim 40$-m-wide zone centered on the crossing $\left(61.549^{\circ} \mathrm{N}, 150.201^{\circ} \mathrm{W}\right)$. Although not observed, there is the possibility that the en echelon scarps east of the route crossing could merge into a single trace at the crossing location. In this case, considering 5-m-high discrete scarps west of the proposed route and two events documented in our trenches, single-event displacements could conceivably be between 1 and $3 \mathrm{~m}$ vertical.

The fault length for the western Castle Mountain fault is around $70 \mathrm{~km}$, which results in an empirically based estimate of maximum earthquake magnitude of moment magnitude $\left(\mathrm{M}_{\mathrm{w}}\right) 7.2$ for future earthquakes along this fault. Based on smoothed seismicity and limited paleoseismic data, Wesson and others (2007) estimated a maximum magnitude $\left(\mathrm{M}_{\max }\right)$ of 7.1 for the Castle Mountain fault.

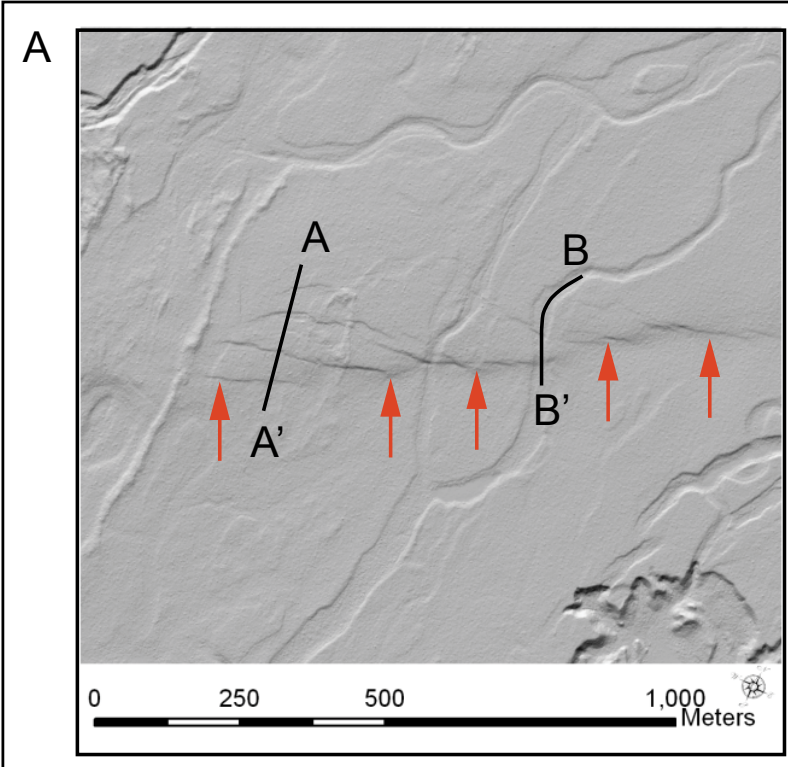

B

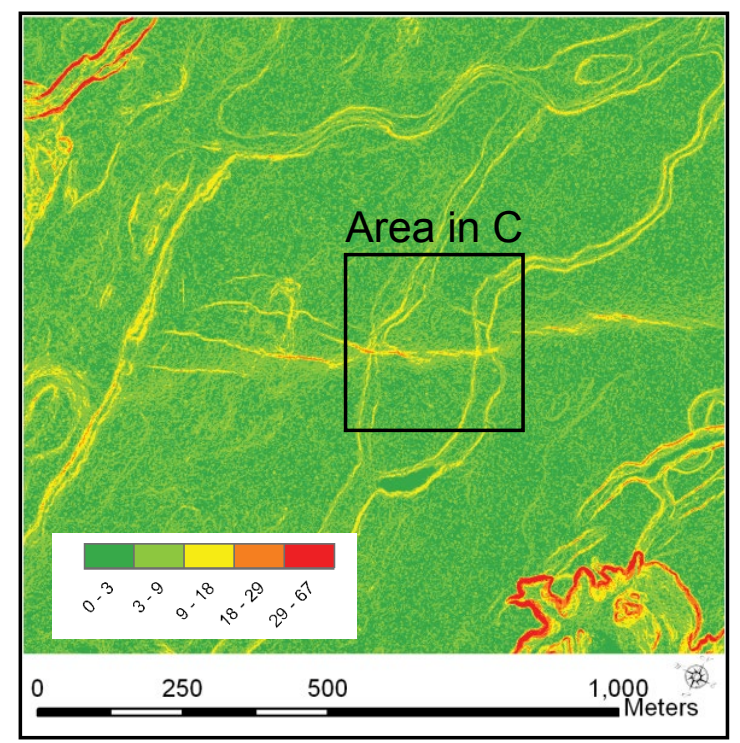

C

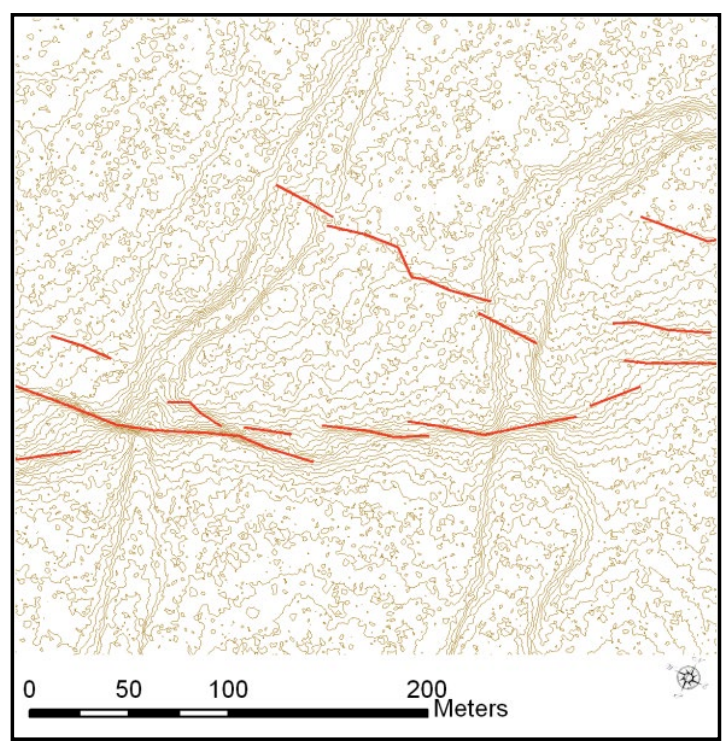

Distance in meters
$\mathrm{D}$

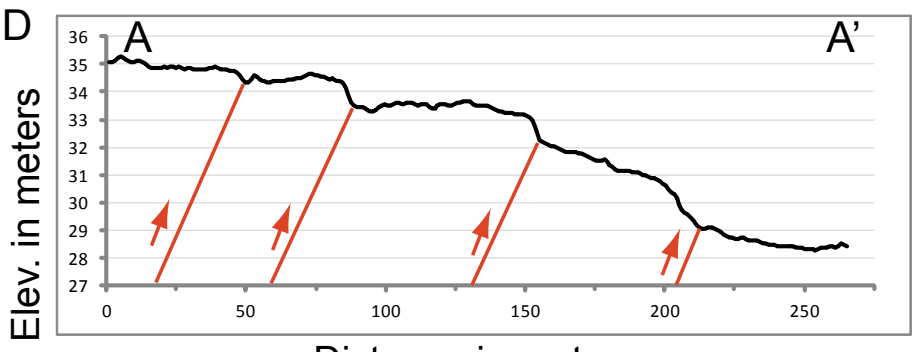

Distance in meters

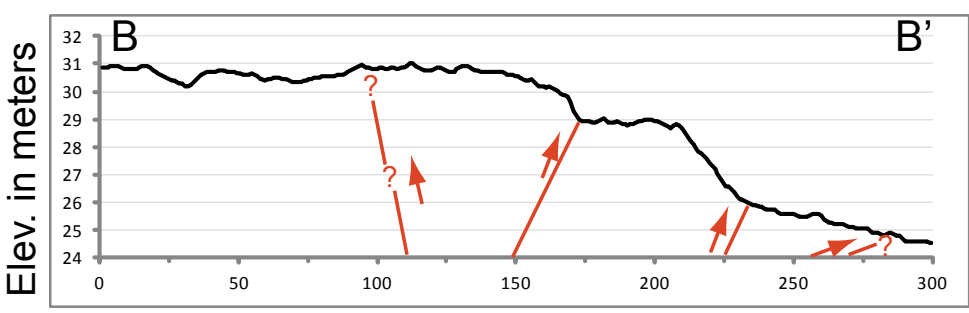

Figure 51. A. Lidar hillshade, B. slope map, and C. 0.5-m-contour map for area west of proposed pipeline crossing, showing little lateral displacement of stream channel margins, left-stepping en echelon scarps, and width of deformation zone. Base of fault scarp shown by red arrows in A. D. Profiles A-A' and B-B'; locations shown in A. 

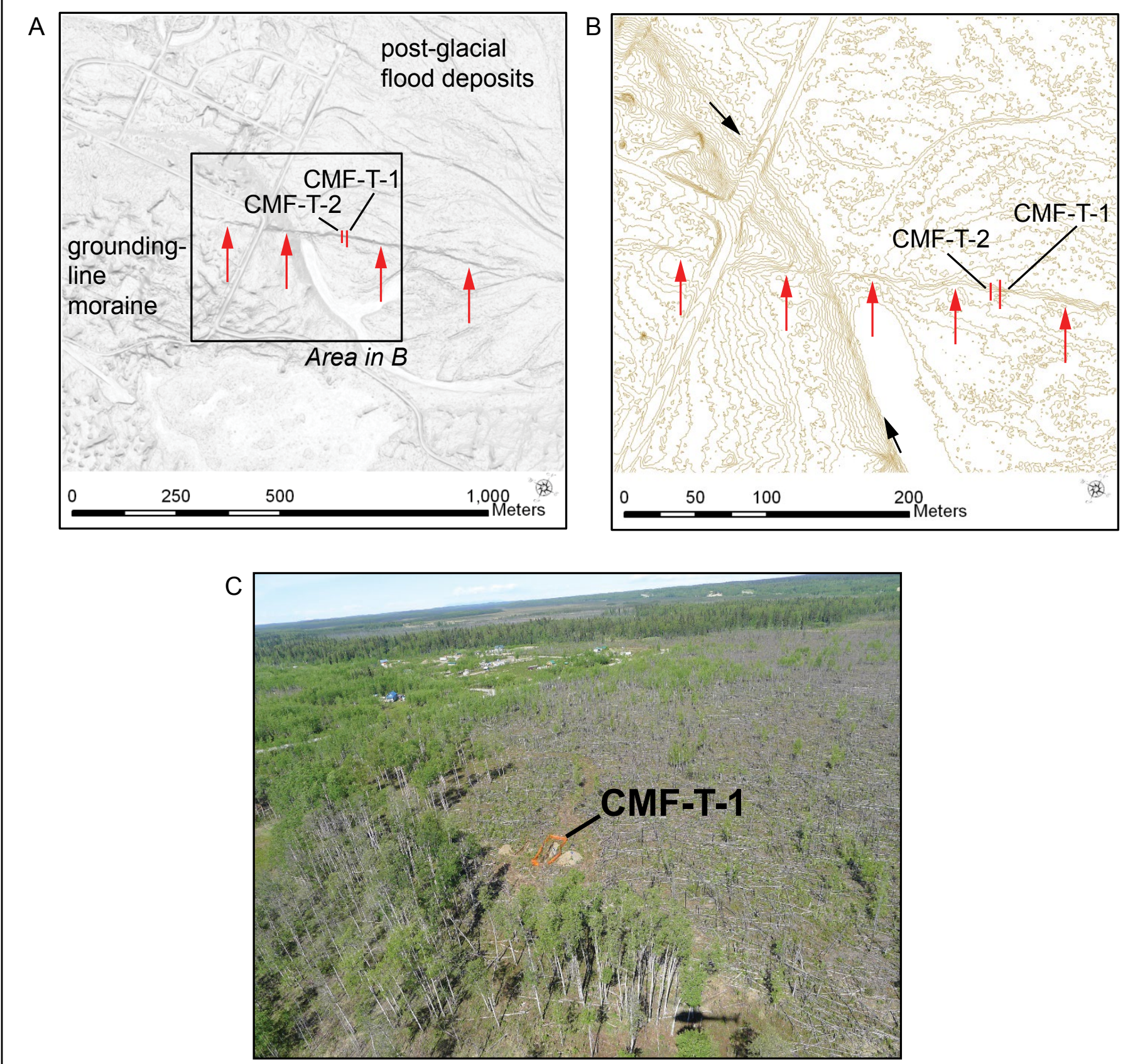

Figure 52. A. Lidar hillshade of the Castle Mountain fault trench sites (T-1 and T-2). B. 0.5-m-contour topographic map of the trench site, showing relatively straight margin of the late Elmendorf grounding-line moraine (between black arrows). Red arrows in A and B point to base of scarp. C. Trench site CMF-T-1, encircled by orange safety fencing; photograph taken from helicopter, looking north, from GPS coordinates $61.617^{\circ} \mathrm{N}, 149.840^{\circ} \mathrm{W}$. 


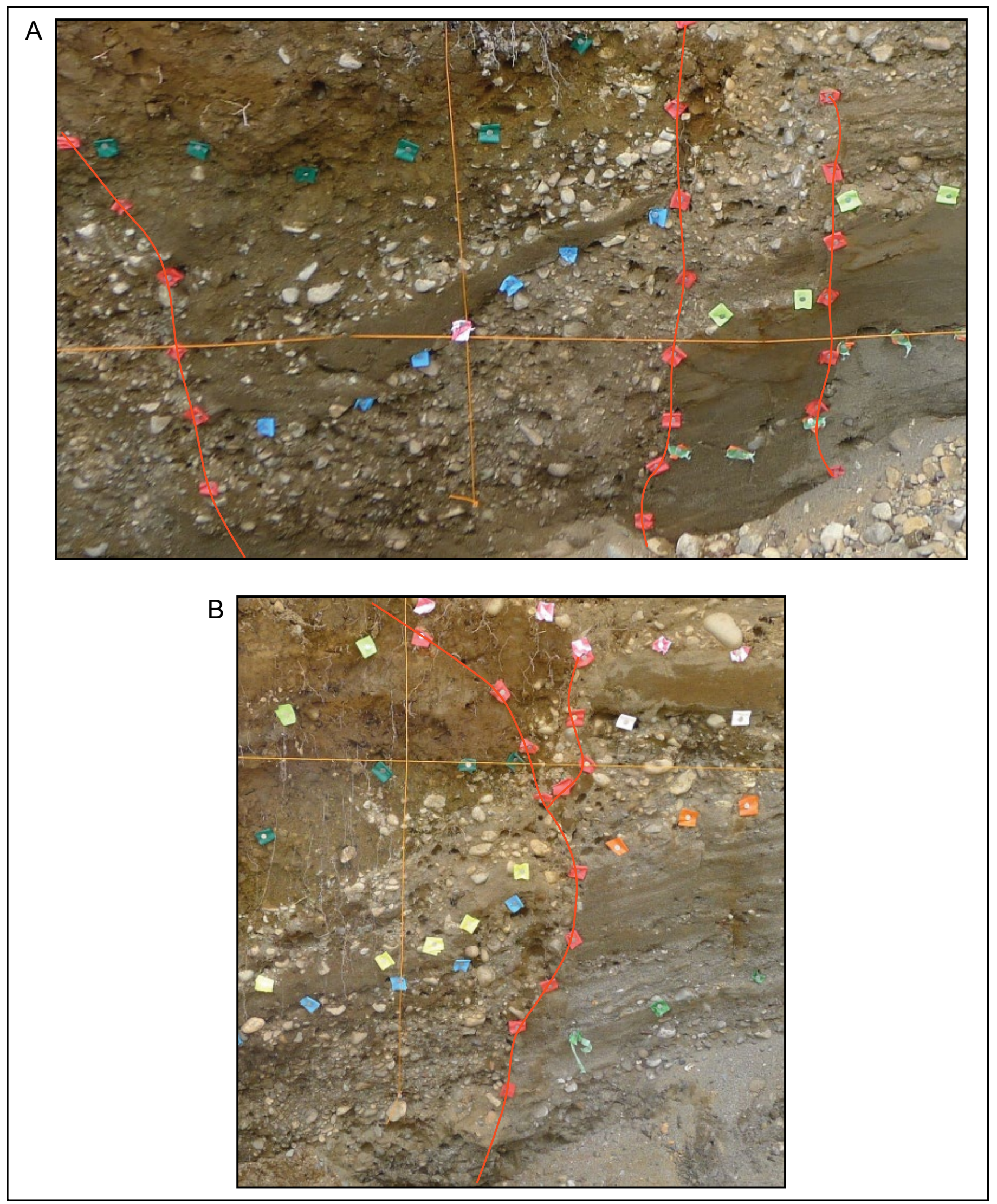

Figure 53. Photographs of faulted fluvial stratigraphy from the Castle Mountain fault trenches. A. Trench CMF-T-1 (west wall). B. Trench CMF-T-2 (west wall). Locations of photos shown on trench logs in figures 54 and 55. 


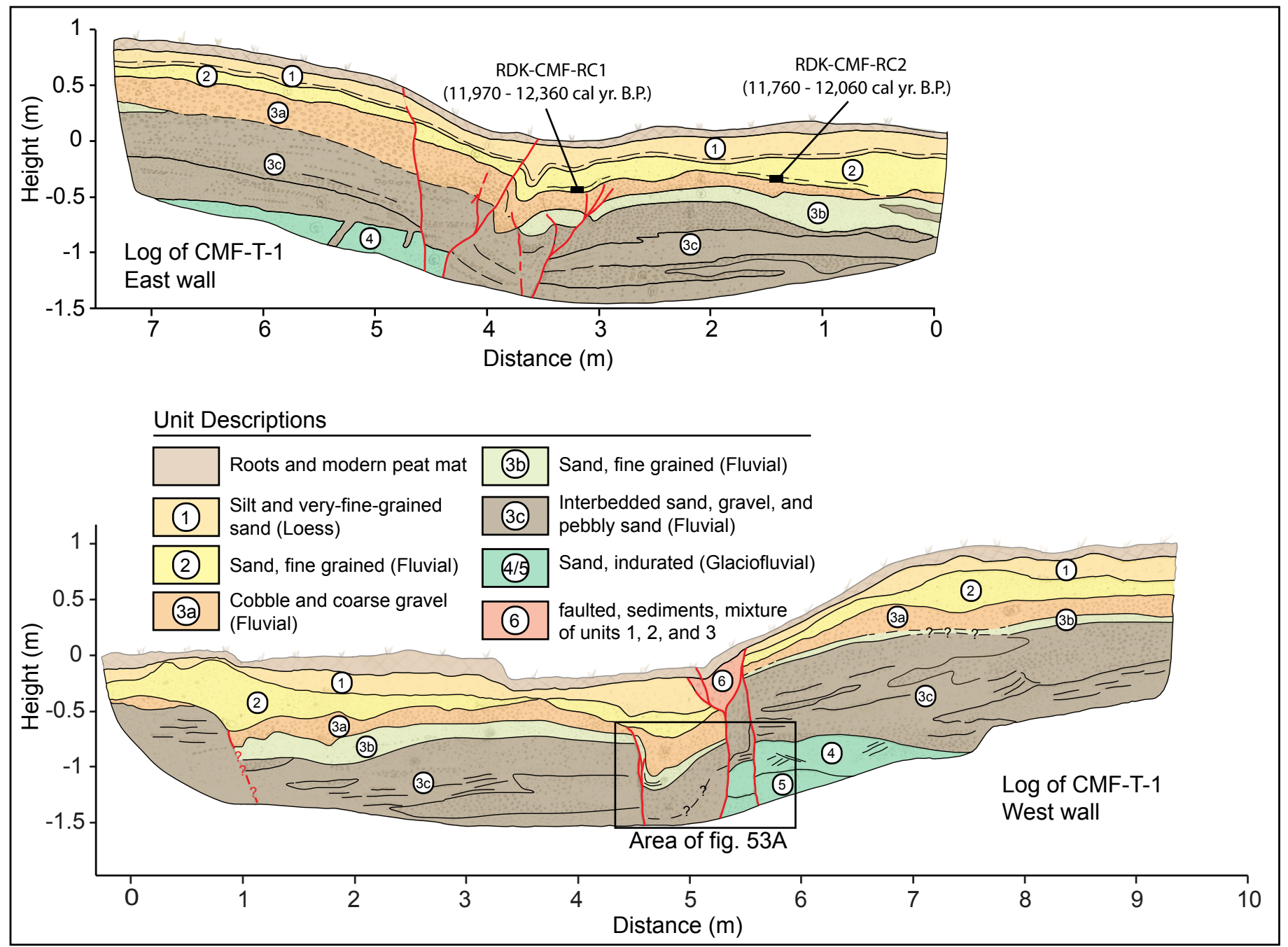

Figure 54. Stratigraphic logs of the east and west walls of trench CMF-T-1. 


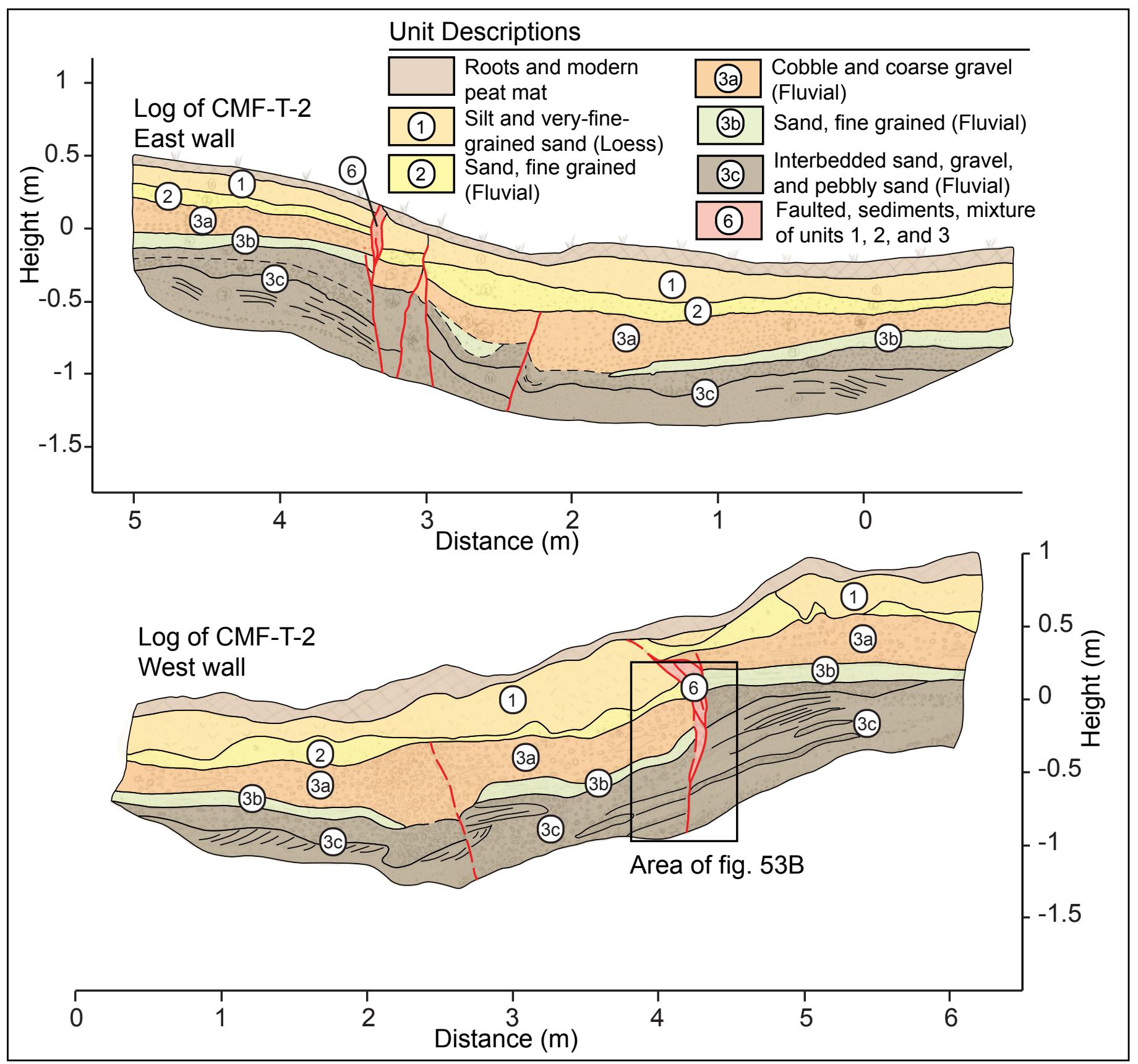

Figure 55. Stratigraphic logs of the east and west walls of trench CMF-T-2. 
The Alaska Division of Geological \& Geophysical Surveys completed surficial-geologic mapping, lidar data evaluations, and paleoseismic trenching investigations along the Minto Flats seismic zone (Minto fault), the Northern Foothills thrust and associated backthrust faults, and the Stampede-Little Panguingue Creek, Healy Creek, Healy, Park Road, Denali, and Castle Mountain faults. Additionally, aerial reconnaissance and lidar assessment were completed along the Tozitna, Kaltag Extension, and Victoria Creek faults. The purpose of these investigations was to summarize the relative tectonic activity for each structure of concern, evaluate fault rupture parameters, and delineate the locations of possible fault crossings of the proposed pipeline route.

Fault rupture parameters for each of the twelve faults or fault zones are summarized in table 2, below. Significant additional conclusions are summarized below.

- Investigations along the Tozitna, Kaltag Extension, and Victoria Creek faults indicate that they are not Holocene-active faults; they were therefore eliminated from consideration. Study of the Tozitna and Kaltag Extension faults was limited to areas covered by lidar along the pipeline route; relative activity east or west of the lidar area cannot be precluded.

- The Minto Flats seismic zone is characterized by frequent, moderate-magnitude earthquakes, and the potential for surface rupture is generally unknown. Investigations along the Minto fault (lineament) indicate that the surface scarp is the product of fluvial erosion associated with the Tanana River and not the product of tectonic displacement. Therefore, surface rupture along the lineament in proximity to the pipeline route was eliminated from consideration.

- Investigations along the Northern Foothills thrust fault indicate that Holocene deposits are not deformed at the pipeline crossing; however, youthful scarps east of the alignment could be Holocene in age. Uncertainties about the fault location, relative activity, and rupture parameters at the proposed pipeline crossing could be resolved with the acquisition and assessment of additional lidar data east and west of the crossing. Thus, we recommend that this additional lidar coverage be acquired.

- Investigations along backthrust faults associated with the Northern Foothills thrust indicate that they are likely Holocene-active tectonic structures.

- Investigations along the Stampede-Little Panguingue Creek fault indicate that the fault is characterized by a low uplift rate and might accommodate slip that steps north from the Healy Creek fault. The fault does not extend across the proposed pipeline route and was eliminated from consideration.

- Investigations along the Healy Creek fault indicate that Holocene deposits are not displaced along the fault. Offset glacial outwash deposits east of the Nenana River could be older than previously documented. The fault is characterized by a low slip rate and is not Holocene active.

- Investigations along the Healy fault indicate that the fault is not expressed at the proposed pipeline crossing. A prominent scarp across Riley Creek-aged fluvial terraces directly east of the proposed pipeline route might or might not be tectonic. Additional paleoseismic trenching is recommended to resolve the origin of the scarp and better define fault-rupture parameters.

- Investigations along the Park Road fault indicate that the fault is not expressed at the proposed pipeline crossing, but is well defined directly west of the Nenana River. The best estimate of the location of the fault at the proposed pipeline route is along the southern canyon wall of Lynx Creek.

- Investigations along the Denali fault indicate that it is not expressed in surficial deposits in the vicinity of the proposed pipeline crossing, but poses a significant surface fault-rupture hazard. Uncertainty in the location of the main surface trace is $>100 \mathrm{~m}$. Rupture parameters for the Denali fault are well understood and the fault is well defined east of the Nenana River, where it crosses a fluvial terrace. Additional ground reconnaissance is recommended to determine whether or not subsidiary strands of the fault mapped by others are active (see purple lines on fig. 39).

- Investigations of the Castle Mountain fault indicate that the fault is expressed as a broad fold $(\sim 1.5 \mathrm{~km})$ in the vicinity of the proposed pipeline crossing. Trenches and surficial mapping nearby indicate that the fault is capable of surface fault ruptures with displacements of 1-3 m vertical and $<1 \mathrm{~m}$ horizontal that could be distributed over a zone up to $150 \mathrm{~m}$ wide. However, en echelon scarps close to the pipeline route occur in a $\sim 40-\mathrm{m}$-wide zone. Projecting this geometry to the pipeline route crossing suggests that 1-3 $\mathrm{m}$ of surface displacement distributed on several fault strands within a 40-m-wide zone is possible. 


\begin{tabular}{|c|c|c|c|c|c|c|c|c|c|c|c|c|}
\hline 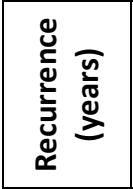 & c. & م. & c. & $\frac{\varangle}{z}$ & $\begin{array}{l}8 \\
0 \\
0 \\
0\end{array}$ & ๘. & 饣. & c. & ค. & 饣. & $\begin{array}{l}8 \\
\text { ஸn } \\
+ \\
+0 \\
8\end{array}$ & 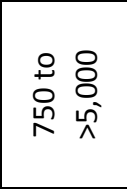 \\
\hline 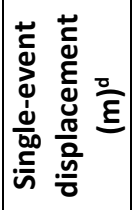 & ळ. & n. & c. & $\frac{\pi}{z}$ & $\stackrel{\vec{I}}{I}$ & $\begin{array}{l}> \\
n \\
t \\
+1 \\
+ \\
0\end{array}$ & 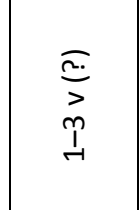 & $\begin{array}{l}\vec{c} \\
> \\
m \\
i\end{array}$ & 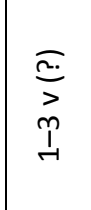 & $\stackrel{\vec{n}}{\sim}$ & $\begin{array}{l}\frac{c}{\infty} \\
> \\
\grave{i}\end{array}$ & $\begin{array}{l}e \\
\vec{v} \\
\vec{I} \\
I \\
\dot{n}\end{array}$ \\
\hline 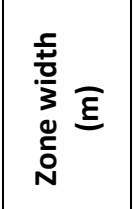 & $\frac{\pi}{z}$ & $\frac{\mathbb{z}}{z}$ & $\frac{\mathbb{z}}{z}$ & $\frac{\pi}{z}$ & $\underset{-1}{\text { ه }}$ & 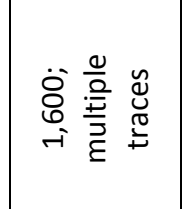 & 饣. & n. & ^. & $\begin{array}{l}\stackrel{P}{1} \\
\stackrel{1}{\sim}\end{array}$ & $\begin{array}{l}8 \\
8 \\
-1 \\
\stackrel{1}{-1}\end{array}$ & 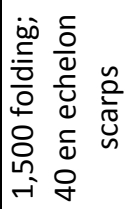 \\
\hline 这 훈 & $\frac{\nwarrow}{z}$ & $\frac{\mathbb{z}}{z}$ & $\frac{\mathbb{z}}{z}$ & $\frac{\varangle}{z}$ & 우 & $m$ & ๘. & c. & 饣. & 우 & $\sim$ & $\stackrel{\sim}{I}$ \\
\hline $\begin{array}{l}\bar{y} \\
\frac{d}{00} \\
\frac{d}{0} \\
\frac{0}{\overline{0}}\end{array}$ & ஜㅇ & ஜ̊ & ஜ̊ & $\frac{\varangle}{z}$ & $\begin{array}{l}n \\
\text { in } \\
\text { ol } \\
\overbrace{n}\end{array}$ & $\begin{array}{l}z \\
0 \\
0 \\
1 \\
i n \\
i n\end{array}$ & $\begin{array}{l}2 \\
0 \\
0 \\
1 \\
0 \\
0\end{array}$ & $\begin{array}{l}2 \\
0 \\
0 \\
1 \\
0 \\
0\end{array}$ & in & $\begin{array}{l}2 \\
0 \\
0 \\
1 \\
0 \\
0 \\
\infty\end{array}$ & 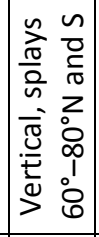 & $\begin{array}{l}z \\
0 \\
0 \\
1 \\
\vdots \\
1\end{array}$ \\
\hline 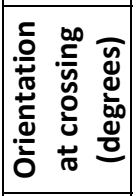 & $\stackrel{\infty}{\stackrel{\infty}{\sim}}$ & $\stackrel{i n}{\sim}$ & $\stackrel{i o j}{\stackrel{i}{\sim}}$ & $\begin{array}{l}\stackrel{\circ}{\circ} \\
\stackrel{ }{N}\end{array}$ & $\begin{array}{l}\stackrel{\infty}{\infty} \\
\stackrel{\sim}{N}\end{array}$ & $\begin{array}{l}\stackrel{\circ}{N} \\
\text { ìn } \\
\grave{i} \\
\stackrel{N}{N}\end{array}$ & $\begin{array}{l}\text { @ì } \\
\stackrel{N}{N}\end{array}$ & $\stackrel{\circ}{\stackrel{\circ}{\sim}}$ & 只 & $\stackrel{i n}{\sim}$ & 足 & $\stackrel{\circ}{\stackrel{i}{\sim}}$ \\
\hline 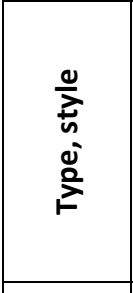 & 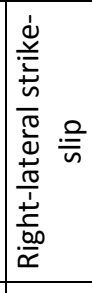 & $\begin{array}{l}\frac{5}{3} \\
0 \\
\frac{c}{5} \\
\frac{5}{5}\end{array}$ & 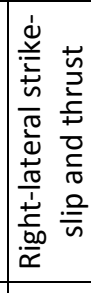 & 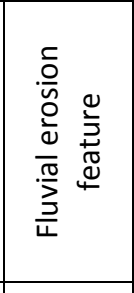 & $\underset{\substack{\frac{n}{2} \\
上}}{F}$ & 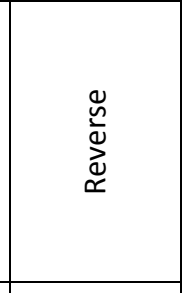 & 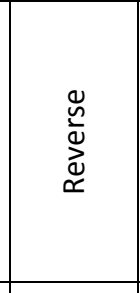 & 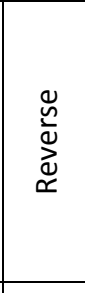 & 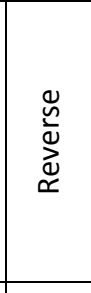 & 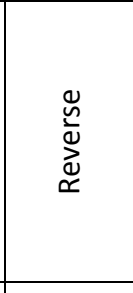 & 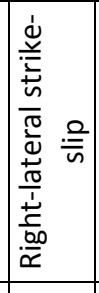 & 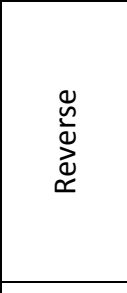 \\
\hline 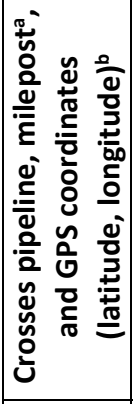 & 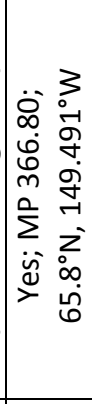 & 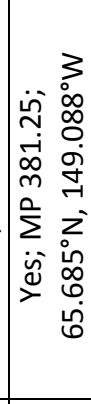 & 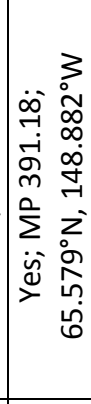 & 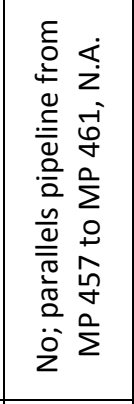 & 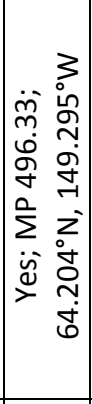 & 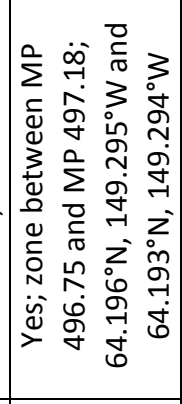 & 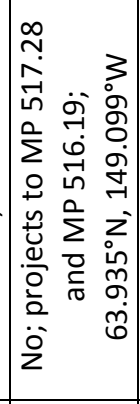 & 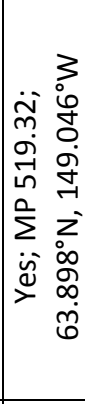 & 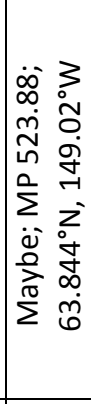 & 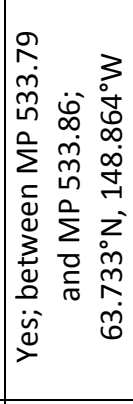 & 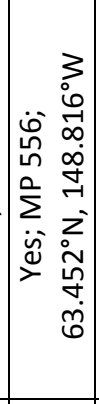 & 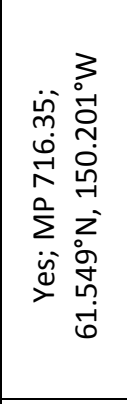 \\
\hline 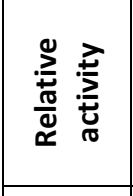 & 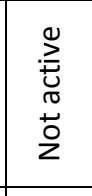 & 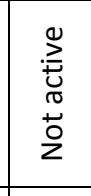 & 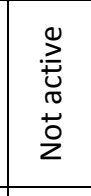 & 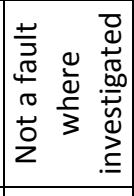 & 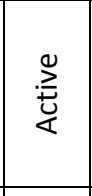 & 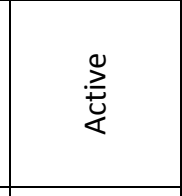 & 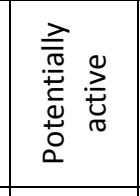 & 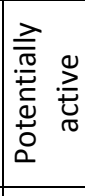 & 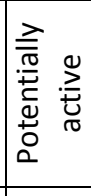 & 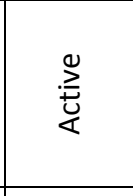 & 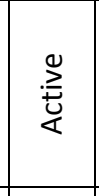 & $\sum_{\stackrel{Z}{*}}^{0}$ \\
\hline $\begin{array}{l}\frac{n}{5} \\
\frac{\pi}{L}\end{array}$ & 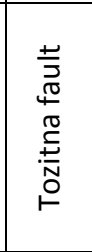 & 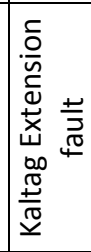 & 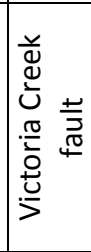 & 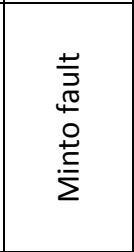 & 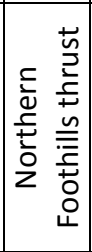 & 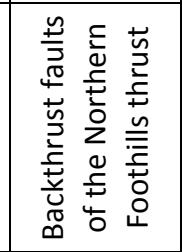 & 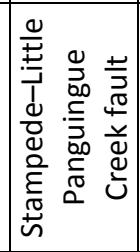 & 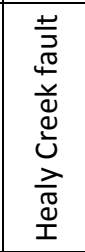 & $\begin{array}{l}\frac{+}{5} \\
\frac{\pi}{\pi} \\
\frac{1}{\pi} \\
\frac{0}{1} \\
\frac{0}{1}\end{array}$ & 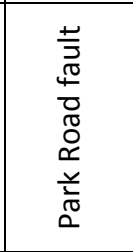 & $\begin{array}{l}\frac{ \pm}{5} \\
\frac{\pi}{\pi} \\
\frac{\bar{\pi}}{\overline{0}} \\
\bar{\Phi} \\
\Delta\end{array}$ & 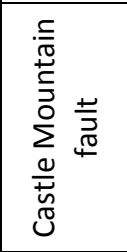 \\
\hline
\end{tabular}

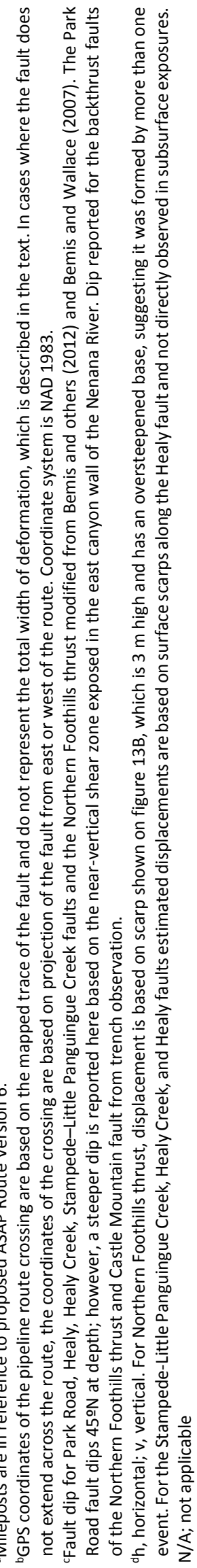


Alaska Earthquake Center (AEC), 2014, www.aeic.alaska.edu, accessed 11/29/2014.

Bemis, S.P., 2004, Neotectonic framework of the north-central Alaska Range foothills: Fairbanks, University of Alaska Fairbanks, M.S. thesis, $142 \mathrm{p}$.

Bemis, S.P., 2010, Moletrack scarps to mountains-Quaternary tectonics of the central Alaska Range: Corvallis, University of Oregon, Ph.D. dissertation, $121 \mathrm{p}$.

Bemis, S.P., and Wallace, W.K., 2007, Neotectonic framework of the north-central Alaska Range foothills, in Ridgway, K.D., Trop, J.M., Glen, J.M.G., and O'Neil, J.M., eds., Tectonic growth of a collisional continental margin - Crustal evolution of southern Alaska: Geological Society of America Special Paper 431, p. 549-572.

Bemis, S.P., Carver, G.A., and Koehler, R.D., 2012, The Quaternary thrust system of the northern Alaska Range: Geosphere, v. 8, no. 1, p. 196-205, 6 figures, 1 table. doi:10.1130/GES00695.1

Benowitz, J.A., Vansant, Galen, Roeske, S.M., Layer, P.W., Hults, C.P., and O’Sullivan, P.B., 2012, Eocene to present slip rate history of the eastern Denali fault system: EOS Transactions, American Geophysical Union, Fall meeting, Abstract \#T11A-2547.

Brogan, G.E., Cluff, L.S., Korringa, M.K., and Slemmons, D.B., 1975, Active faults of Alaska: Tectonophysics, v. 29, p. $73-85$.

Carver, G.A., Plafker, George, Metz, M., Cluff, L.S., Slemmons, D.B., Johnson, E., Roddick, J., and Sorensen, S., 2004, Surface rupture on the Denali fault interpreted from tree damage during the 1912 Delta River $\mathrm{M}_{\mathrm{w}}$ 7.2-7.4 earthquake-Implications for the 2002 Denali fault earthquake slip distribution, in Rowe, C.A., Christenson, D., and Carver, G.A., eds., The 2002 Denali fault earthquake sequence, dedicated issue: Bulletin of the Seismological Society of America, v. 94, no. 6, Part B, p. 58-71.

Detterman, R.L., Plafker, George, Hudson, Travis, Tysdal, R.G., and Pavoni, Nazario, 1974, Surface geology and Holocene breaks along the Susitna segment of the Castle Mountain fault, Alaska: U.S. Geological Survey Miscellaneous Field Studies Map 618, 1 sheet, scale 1:24,000.

Devore, J.R., Bemis, S.P., and Walker, L.A., 2012, Evidence for post-26 ka displacement of the Northern Foothills thrust at the Nenana River, Alaska: EOS Transactions, American Geophysical Union annual meeting, Abstract \#T11A-2552.

Eberhart-Phillips, Donna, Haeussler, P.J., Freymueller, J.T., Frankel, A.D., Rubin, C.M., Craw, P.A., Ratchkovski, N.A., Anderson, Greg, Carver, G.A., Crone, A.J., Dawson, T.E., Fletcher, Hilary, Hansen, Roger, Harp, E.L., Harris, R.A., Hill, D.P., Hreinsdottir, Sigrun, Jibson, R.W., Jones, L.M., Kayen, R.E., Keefer, D.K., Larsen, C.F., Moran, S.C., Personius, S.F., Plafker, George, Sherrod, B.L., Sieh, Kerry, Sitar, Nicholas, and Wallace, W.K., 2003, The 2002 Denali fault earthquake, Alaska—A large magnitude, slip-partitioned event: Science, v. 300, no. 5622, p. 1,113-1,118.

Fletcher, H.J., 2002, Crustal deformation in Alaska measured using the Global Positioning System: Fairbanks, University of Alaska Fairbanks, Ph.D. dissertation, 135 p.

Foster, H.L., Laird, Jo, Keith, T.E.C., Cushing, G.W., and Menzie, W.D., 1983, Preliminary geologic map of the Circle Quadrangle, Alaska: U.S. Geological Survey Open-File report 83-170A, 30 p., 1 sheet, scale 1:250,000.

Freymueller, J.T., Haeussler, P.J., Wesson, R.L., and Ekström, Goran, eds., 2008, Active tectonics and seismic potential of Alaska: Washington, D.C., American Geophysical Union, Geophysical Monograph 179, 430 p.

Fuchs, W.A., 1980, Tertiary tectonic history of the Castle Mountain fault-Caribou fault system in the Talkeetna Mountains, Alaska: Salt Lake City, University of Utah, Ph.D. dissertation, 152 p.

Gedney, L., Shapiro, L., VanWormer, D., and Weber, F.R., 1972, Correlation of epicenters with mapped faults, east-central Alaska, 1968-1971: U.S. Geological Survey Open-File Report 72-128, 7 p., 1 sheet, scale 1:1,000,000.

Grantz, Arthur, 1966, Strike-slip faults in Alaska: U.S. Geological Survey Open-File Report 267, 82 p.

Haeussler, P.J., Best, T.C., and Waythomas, C.F., 2002, Paleoseismology at high latitudes-Seismic disturbance of upper Quaternary deposits along the Castle Mountain fault near Houston, Alaska: Geological Society of America Bulletin, v. 114, no. 10, p. $1,296-1,310,1$ sheet.

Haeussler, P.J., Bruhn, R.L., and Pratt, T.L., 2000, Potential seismic hazards and tectonics of the upper Cook Inlet basin, Alaska, based on analysis of Pliocene and younger deformation: Geological Society of America Bulletin, v. 112, no. 9, p. 1,414-1,429.

Haeussler, P.J., Schwartz, D.P., Dawson, T.E., Stenner, H.D., Lienkaemper, J.J., Sherrod, Brian, Cinti, F.R., Montone, Paola, Craw, P.A., Crone, A.J., and Personius, S.F., 2004, Surface rupture and slip distribution of the Denali and Totschunda faults in the 3 November 2002 M 7.9 earthquake, Alaska: Bulletin of the Seismological Society of America, v. 94, no. 6, Part B, p. $23-52$. 
Hubbard, T.D., Koehler, R.D., and Combellick, R.A., 2011, High-resolution lidar data for Alaska infrastructure corridors, in DGGS Staff, LiDAR Datasets of Alaska: Alaska Division of Geological \& Geophysical Surveys Raw Data File 2011-3, 291 p. doi: $10.14509 / 22722$

Kelly, T.E., 1963, Geology and hydrocarbons in Cook Inlet basin, Alaska: American Association of Petroleum Geologists Memoir, v. 2, p. 278-296.

Koehler, R.D., Farrell, R.-E., Burns, P.A.C., and Combellick, R.A., 2012a, Quaternary faults and folds in Alaska-A digital database, in Koehler, R.D., Quaternary faults and folds (QFF): Alaska Division of Geological \& Geophysical Surveys Miscellaneous Publication 141, 31 p., 1 sheet, scale 1:3,700,000. doi:10.14509/23944

Koehler, R.D., Reger, R.D., and Frohman, R.A., 2012b, The Castle Mountain fault, south-central Alaska-New lidar-based observations on the sense of slip: EOS Transactions, American Geophysical Union, Fall Meeting Supplement, Abstract \#S53D-2530.

Koehler, R.D., Schwartz, D.P., Rood, D., Reger, R.D., and Wolken, Gabriel, 2013, Preliminary paleoseismic observations along the central Denali fault, Alaska, EOS Transactions, American Geophysical Union, Fall Meeting Supplement, Abstract \#T23C-2598.

Lahr, J.C., Page, R.A., Stephens, C.D., and Fogleman, K.A., 1986, Sutton, Alaska, earthquake of 1984-Evidence for activity on the Talkeetna segment of the Castle Mountain fault system: Bulletin of the Seismological Society of America, v. 76, no. 4, p. 967-983.

Matmon, A., Schwartz, D.P., Haeussler, P.J., Finke, R., Lienkaemper, J.J., Stenner, H.D., and Dawson, T.E., 2006, Denali fault slip rates and Holocene-Late Pleistocene kinematics of central Alaska: Geology, v. 34, no. 8, p. 645-648. doi:10.1130/G22361.1

Mériaux, A.-S., Sieh, K., Finkel, R.C., Rubin, C.M., Taylor, M.H., Meltzner, A.J., and Ryerson, F.J., 2009, Kinematic behavior of southern Alaska constrained by westward decreasing postglacial slip rates on the Denali fault, Alaska: Journal of Geophysical Research, v. 114, no. B3, p. 404. doi:10.1029/2007JB005053.

Mull, C.G., and Adams, K.E., eds., 1989, Bedrock geology of the eastern Koyukuk Basin, central Brooks Range, and east-central Arctic Slope along the Dalton Highway, Yukon River to Prudhoe Bay, Alaska, Volume 1: Alaska Division of Geological \& Geophysical Surveys Guidebook 7, v. 1, 309 p., 1 sheet, scale 1 inch = 45 miles. doi: $\underline{10.14509 / 269}$

Nokleberg, W.J., Jones, D.L., and Silberling, N.J., 1985, Origin and tectonic evolution of the Maclaren and Wrangellia terranes, eastern Alaska Range, Alaska: Geological Society of America Bulletin, v. 96, no. 10, p. 1,251-1,270.

Page, R.A., Plafker, George, and Pulpan, Hans, 1995, Block rotation in east-central Alaska-A framework for evaluating earthquake potential?: Geology, v. 23, no. 7, p. 629-632.

Patton, W.W., Jr., and Hoare, J.M., 1968, The Kaltag fault, west-central Alaska: U.S. Geological Survey Professional Paper 600-D., p. D147-D153.

Péwé, T.L., Wahrhaftig, Clyde, and Weber, F.R., 1966, Geologic map of the Fairbanks Quadrangle, Alaska: U.S. Geological Survey Miscellaneous Geologic Investigations Map 455, 5 p., 1 sheet, scale 1:250,000.

Plafker, George, Carver, G.A., Metz, M., and Cluff, L.S., 2004, Repeated historic surface ruptures of the Denali fault at Delta River, Alaska, during large earthquakes in 1912 and 2002: EOS Transactions, American Geophysical Union, Fall meeting, Abstract \#G11A-0780.

Plafker, George, Hudson, Travis, and Richter, D.H., 1977, Preliminary observations on late Cenozoic displacements along the Totschunda and Denali fault system, in Blean, K.M., ed., The United States Geological Survey in Alaska: Accomplishments during 1976: U.S. Geological Survey Circular 751-B, p. B67-69.

Schwartz, D.P., Dawson, T.E., Haeussler, P.J., Lienkaemper, J.J., Matmon, A., Stenner, H.D., Sherrod, Brian, Cinti, F.R., Montone, Paola, Carver, G.A., and Plafker, George, 2003, Paleo-earthquakes on the Denali-Totschunda fault system-Preliminary observations of slip and timing: American Geophysical Union, fall meeting, abstract \#S11B-03.

Schwartz, D.P., Haeussler, P.J., Seitz, G.G., Dawson, T.E., Stenner, H.D., Crone, A.J., Personius, S.F., Cadena, A., and Armstrong, P., [in review], Field data and preliminary interpretations at four paleoseismic sites on the western Denali fault, Alaska: U.S. Geological Survey Open-File Report.

St. Amand, Pierre, 1957, Geological and geophysical synthesis of the tectonics of portions of British Columbia, the Yukon Territory, and Alaska: Geological Society of America Bulletin, v. 68, no. 10, p. 1,343-1,370.

Tape, Carl, West, Michael, Silwal, Vipul, and Ruppert, Natalia, 2013, Earthquake nucleation and triggering on an optimally oriented fault: Earth and Planetary Science Letters, v. 363, p. 231-241.

Taylor, T.P., and Bemis, S.P., 2012, Paleoseismology of the Denali fault at the Nenana River: EOS Transactions, American Geophysical Union, Fall Meeting, Abstract \#T11A-2551. 
Ten Brink, N.W., and Waythomas, C.F., 1985, Late Wisconsin glacial chronology of the north-central Alaska Range-A regional synthesis and its implications for early human settlements, in Powers, W.R., and others, eds., North Alaska Range Early Man Project: National Geographic Society Research Reports, v. 19, p. 15-32.

Thorson, R.M., 1979, Recurrent late Quaternary faulting near Healy, Alaska, in Short Notes on Alaskan Geology, 1978: Alaska Division of Geological \& Geophysical Surveys Geologic Report 61C, p. 10-14. doi:10.14509/410

Wahrhaftig, Clyde, 1958, Quaternary geology of the Nenana River valley and adjacent parts of the Alaska Range: U.S. Geological Survey Professional Paper 293-A, 118 p.

Wahrhaftig, Clyde, 1970a, Geologic map of the Healy D-4 Quadrangle, Alaska: U.S. Geological Survey Quadrangle Map GQ-806, scale $1: 63,360$.

Wahrhaftig, Clyde, 1970b, Geologic map of the Healy D-5 Quadrangle, Alaska: U.S. Geological Survey Quadrangle Map GQ-807, scale $1: 63,360$.

Weber, F.R., Wheeler, K.L., Rinehart, C.D., Chapman, R.M., and Blodgett, R.B., 1992, Geologic map of the Livengood Quadrangle, Alaska, U.S. Geological Survey, Open-File Report 92-562, 20 p., 1 sheet, scale 1:250,000.

Weber, F.R., Wheeler, K.L., Rinehart, C.D., and Light, T.D., 1997, Generalized geologic map of the Livengood Quadrangle, Alaska, U.S. Geological Survey Open-File Report 97-484-A, 1 sheet, scale 1:250,000.

Wells, D.L., and Coppersmith, K.J., 1994, New empirical relationships among magnitude, rupture length, rupture width, rupture area, and surface displacement: Bulletin of the Seismological Society of America, v. 84, no. 4, p. 974-1,002.

Wesson, R.L., Boyd, O.S., Mueller, C.S., Bufe, C.G., Frankel, A.D., and Petersen, M.D., 2007, Revision of time-independent probabilistic seismic hazard maps for Alaska, U.S. Geological Survey Open-File Report 2007-1043, 33 p.

Wickens, A.J., and Hodgson, J.H., 1967, Computer re-evaluation of earthquake mechanism solutions, 1922-1962: Ottawa, Ontario, Publications of the Dominion Observatory, Department of Energy, Mines, and Resources, Observatories Branch, v. 33, no. 1, 560 p.

Willis, J.B., Haeussler, P.J., Bruhn, R.L., and Willis, G.C., 2007, Holocene slip rate for the western segment of the Castle Mountain fault, Alaska: Bulletin of the Seismological Society of America, v. 97, no. 3, p. 1,019-1,024. 


\section{References for previously-mapped faults shown on map figures}

\section{Figure 2}

Grantz, Arthur, Moore, T.E., and Roeske, S.M., 1991, Transect A-3 - Gulf of Alaska to Arctic Ocean: Geological Society of America, Centennial continent/Ocean Transect, v. 15, 3 sheets, scale 1:500,000.

Koehler, R.D., Farrell, Rebecca-Ellen, Burns, P.A.C., and Combellick, R.A., 2012, Quaternary faults and folds in Alaska-A digital database, in Koehler, R.D., Quaternary faults and folds (QFF): Alaska Division of Geological \& Geophysical Surveys Miscellaneous Publication 141, 31 p., 1 sheet, scale 1:3,700,000. doi:10.14509/23944

Labay, K.A., Crews, Jesse, Wilson, F.H., Shew, Nora, Hults, C.K., Till, A.B., Dumoulin, J.A., Phillips, J.D., and Stanley, R.G., 2006, Preliminary integrated geologic map databases for the United States-Digital data for the generalized bedrock geologic map, Yukon Flats region, east-central Alaska: U.S. Geological Survey Open-File Report 2006-1304, 1 p.

Plafker, George, Gilpin, L.M., and Lahr, J.C., 1994, Neotectonic map of Alaska, in Plafker, George, and Berg, H.C., The Geology of Alaska: Geological Society of America, 2 sheets, scale 1:2,500,000.

Weber, F.R., Wheeler, K.L., Rinehart, C.D., and Light, T.D., 1997, Generalized geologic map of the Livengood Quadrangle, Alaska: U.S. Geological Survey Open-File Report 97-484-A, 1 sheet, scale 1:250,000.

\section{Figure 3}

Grantz, Arthur, Moore, T.E., and Roeske, S.M., 1991, Transect A-3 - Gulf of Alaska to Arctic Ocean: Geological Society of America, Centennial continent/Ocean Transect, v. 15, 3 sheets, scale 1:500,000.

Jones, D.L., Silberling, N.J., Gilbert, W.G., and Coney, P.J., 1983, Tectono-stratigraphic map and interpretive bedrock geologic map of the Mount McKinley region, Alaska: U.S. Geological Survey Open-File Report 83-11, 2 sheets, scale 1:250,000.

\section{Figure 22}

Csejtey, Béla, Jr., Mullen, M.W., Cox, D.P., and Stricker, G.D., 1992, Geology and geochronology of the Healy Quadrangle, south-central Alaska: U.S. Geological Survey Miscellaneous Investigations Series Map 1961, 63 p., 2 sheets, scale 1:250,000.

Grantz, Arthur, Moore, T.E., and Roeske, S.M., 1991, Transect A-3 - Gulf of Alaska to Arctic Ocean: Geological Society of America, Centennial continent/Ocean Transect, v. 15, 3 sheets, scale 1:500,000.

Jones, D.L., Silberling, N.J., Gilbert, W.G., and Coney, P.J., 1983, Tectono-stratigraphic map and interpretive bedrock geologic map of the Mount McKinley region, Alaska: U.S. Geological Survey Open-File Report 83-11, 2 sheets, scale 1:250,000.

\section{Figure 33}

Csejtey, Béla, Jr., Mullen, M.W., Cox, D.P., and Stricker, G.D., 1992, Geology and geochronology of the Healy Quadrangle, south-central Alaska: U.S. Geological Survey Miscellaneous Investigations Series Map 1961, 63 p., 2 sheets, scale 1:250,000.

Frost, G.M., Barnes, D.F., and Stanley, R.G., 2002, Geologic and isostatic gravity map of the Nenana basin area, central Alaska: U.S. Geological Survey Geologic Investigations Series Map 2543, 16 p., 2 sheets, scale 1:250,000.

Grantz, Arthur, Moore, T.E., and Roeske, S.M., 1991, Transect A-3 - Gulf of Alaska to Arctic Ocean: Geological Society of America, Centennial continent/Ocean Transect, v. 15, 3 sheets, scale 1:500,000.

Hickman, R.G., and Craddock, Campbell, 1976, Geologic maps of the west-central and central Healy Quadrangle, Alaska: Alaska Division of Geological \& Geophysical Surveys Alaska Open-File Report 95, 3 sheets, scale 1:63,360. doi:10.14509/191

Jones, D.L., Silberling, N.J., Gilbert, W.G., and Coney, P.J., 1983, Tectono-stratigraphic map and interpretive bedrock geologic map of the Mount McKinley region, Alaska: U.S. Geological Survey Open-File Report 83-11, 2 sheets, scale 1:250,000.

Sherwood, K.W., and Craddock, Campbell, 1979, General geology of the central Alaska Range between the Nenana River and Mount Deborah: Alaska Division of Geological \& Geophysical Surveys Alaska Open-File Report 116, 24 p., 3 sheets, scale 1:63,360. doi: $10.14509 / 32$

Wahrhaftig, Clyde, and Black, R.F., 1958, Quaternary and engineering geology in the central part of the Alaska Range: U.S. Geological Survey Professional Paper 293, 118 p., 7 sheets, scale 1:250,000. 


\section{Figure 39}

Capps, S.R., 1933, The eastern portion of Mount McKinley National Park, in U.S. Geological Survey, Mineral resources of AlaskaReport on progress of investigations in 1930: U.S. Geological Survey Bulletin 836, p. 219-300, 1 sheet, scale 1:250,000.

Capps, S.R., 1940, Geology of the Alaska Railroad region: U.S. Geological Survey Bulletin 907, 201 p., 3 sheets, scale 1:250,000.

Csejtey, Béla, Jr., Mullen, M.W., Cox, D.P., and Stricker, G.D., 1992, Geology and geochronology of the Healy Quadrangle, south-central Alaska: U.S. Geological Survey Miscellaneous Investigations Series Map 1961, 63 p., 2 sheets, scale 1:250,000.

Hickman, R.G., and Craddock, Campbell, 1976, Geologic maps of the west-central and central Healy Quadrangle, Alaska: Alaska Division of Geological \& Geophysical Surveys Alaska Open-File Report 95, 3 sheets, scale 1:63,360. doi:10.14509/191

Jones, D.L., Silberling, N.J., Gilbert, W.G., and Coney, P.J., 1983, Tectono-stratigraphic map and interpretive bedrock geologic map of the Mount McKinley region, Alaska: U.S. Geological Survey Open-File Report 83-11, 2 sheets, scale 1:250,000.

Moxham, R.M., and Eckhart, R.A., 1959, Geology and cement raw materials of the Windy Creek area, Alaska: U.S. Geological Survey Bulletin 1039-D, p. 67-100, 1 sheet, scale 1:48,000.

Sherwood, K.W., and Craddock, Campbell, 1979, General geology of the central Alaska Range between the Nenana River and Mount Deborah: Alaska Division of Geological \& Geophysical Surveys Alaska Open-File Report 116, 24 p., 3 sheets, scale 1:63,360. doi: $10.14509 / 32$

Wahrhaftig, Clyde, and Black, R.F., 1958, Quaternary and engineering geology in the central part of the Alaska Range: U.S. Geological Survey Professional Paper 293, 118 p., 7 sheets, scale 1:250,000.

Wilson, F.H., Dover, J.H., Bradley, D.C., Weber, F.R., Bundtzen, T.K., and Haeussler, P.J., 1998, Geologic map of central (interior) Alaska: U.S. Geological Survey Open-File Report 98-133-A, 62 p., 3 sheets. http://pubs.er.usgs.gov/publication/ofr98133B

\section{Figure 48}

Koehler, R.D., Farrell, Rebecca-Ellen, Burns, P.A.C., and Combellick, R.A., 2012, Quaternary faults and folds in Alaska-A digital database, in Koehler, R.D., Quaternary faults and folds (QFF): Alaska Division of Geological \& Geophysical Surveys Miscellaneous Publication 141, 31 p., 1 sheet, scale 1:3,700,000. doi:10.14509/23944

Labay, K.A., and Haeussler, P.J., 2001, GIS coverages of the Castle Mountain Fault, south-central Alaska: U.S. Geological Survey Open-File Report 2001-504. http://pubs.er.usgs.gov/publication/ofr01504

Wilson, F.H., Dover, J.H., Bradley, D.C., Weber, F.R., Bundtzen, T.K., and Haeussler, P.J., 1998, Geologic map of central (interior) Alaska: U.S. Geological Survey Open-File Report 98-133-A, 62 p., 3 sheets. http://pubs.er.usgs.gov/publication/ofr98133B 
Summary of laboratory results and calibration probability density functions for radiocarbon samples collected from trenches excavated across the Minto Fault, Northern Foothills backthrust faults, and the Castle Mountain fault. Analyses performed at PaleoResearch Facilities.

\begin{tabular}{|c|c|c|c|c|c|c|}
\hline Sample & Lab No. & Sample Identification & $\begin{array}{c}\text { AMS }^{14} \mathrm{C} \\
\text { Date }^{\mathrm{a}}\end{array}$ & $\begin{array}{c}\text { 1-sigma } \\
\text { Calibrated Date } \\
(68.2 \%)\end{array}$ & $\begin{array}{c}\text { 2-sigma } \\
\text { Calibrated } \\
\text { Date }(95.4 \%)\end{array}$ & $\begin{array}{r}{ }^{* 13} \mathrm{C}^{\mathrm{b}} \\
(\% \mathrm{o})\end{array}$ \\
\hline \multicolumn{7}{|c|}{ Minto Fault Trench (MF-T1) } \\
\hline RDK-FF-1 & $\begin{array}{l}\text { PRI-515-008- } \\
\text { RDK-MF-1 }\end{array}$ & $\begin{array}{l}\text { Salicaceae and } \\
\text { unidentified hardwood } \\
\text { charcoal }\end{array}$ & $\begin{array}{c}10,166 \pm 33 \\
\text { RCYBP }\end{array}$ & $\begin{array}{c}11,970-11,860 \\
11,840-11,760 \\
\text { CAL yr BP }\end{array}$ & $\begin{array}{c}12,030-11,710 \\
\text { CAL yr BP }\end{array}$ & -25.0 \\
\hline \multicolumn{7}{|c|}{ Northern Foothills Thrust Trench (NFT-T-1) } \\
\hline NFT-T1-RDK3 & $\begin{array}{l}\text { PRI-15-008- } \\
\text { NFT-T1-RDK3 }\end{array}$ & Picea charcoal & $\begin{array}{c}3,209 \pm 22 \\
\text { RCYBP }\end{array}$ & $\begin{array}{c}3,450-3,400 \\
\text { CAL yr BP }\end{array}$ & $\begin{array}{c}3,470-3,380 \\
\text { CAL yr BP }\end{array}$ & -23.4 \\
\hline NFT-T1-RDK1 & $\begin{array}{l}\text { PRI-15-008- } \\
\text { NFT-T1-RDK1 }\end{array}$ & Picea charcoal & $\begin{array}{c}2,805 \pm 22 \\
\text { RCYBP }\end{array}$ & $\begin{array}{c}2,945-2,870 \\
C A L \text { yr BP }\end{array}$ & $\begin{array}{c}2,970-2,850 \\
C A L \text { yr BP }\end{array}$ & -25.9 \\
\hline NFT-T1-RDK4 & $\begin{array}{l}\text { PRI-15-008- } \\
\text { NFT-T1-RDK4 }\end{array}$ & Picea charcoal & $\begin{array}{c}4,803 \pm 22 \\
\text { RCYBP }\end{array}$ & $\begin{array}{c}5,590-5,580 \\
5,530-5,480 \\
\text { CAL yr BP }\end{array}$ & $\begin{array}{c}5,600-5,570 \\
5,550-5,470 \\
\text { CAL yr BP }\end{array}$ & -23.7 \\
\hline NFT-T1-RDK5 & $\begin{array}{l}\text { PRI-15-008- } \\
\text { NFT-T1-RDK5 }\end{array}$ & Picea charcoal & $\begin{array}{c}4,767 \pm 23 \\
\text { RCYBP }\end{array}$ & $\begin{array}{c}5,590-5,570 \\
5,550-5,500 \\
5,490-5,470 \\
\text { CAL yr BP }\end{array}$ & $\begin{array}{c}5,590-5,460 \\
\text { CAL yr BP }\end{array}$ & -25.9 \\
\hline \multicolumn{7}{|c|}{ Castle Mountain Fault Trench (CMF-T1) } \\
\hline RDK-CMF-RC1 & $\begin{array}{l}\text { PRI-15-008- } \\
\text { RDK-CMF- } \\
\text { RC1 }\end{array}$ & $\begin{array}{l}\text { Unidentified seed, } \\
\text { vitrified }\end{array}$ & $\begin{array}{c}10,306 \pm 32 \\
\text { RCYBP }\end{array}$ & $\begin{array}{c}12,160-12,030 \\
\text { CAL yr BP }\end{array}$ & $\begin{array}{c}12,360-12,310 \\
12,300-12,270 \\
12,240-11.970 \\
\text { CAL yr BP }\end{array}$ & -24.6 \\
\hline RDK-CMF-RC2 & $\begin{array}{l}\text { PRI-15-008- } \\
\text { RDK-CMF- } \\
\text { RC2 }\end{array}$ & $\begin{array}{l}\text { Arctostaphylos seed, } \\
\text { charred }\end{array}$ & $\begin{array}{c}10,205 \pm 34 \\
\text { RCYBP }\end{array}$ & $\begin{array}{c}12,030-11,950 \\
11,930-11,820 \\
\text { CAL yr BP }\end{array}$ & $\begin{array}{c}12,060-11,760 \\
\text { CAL yr BP }\end{array}$ & -21.5 \\
\hline
\end{tabular}

${ }^{a}$ Reported in radiocarbon years at 1 standard deviation measurement precision $(68.2 \%)$, corrected for ${ }^{* 13} \mathrm{C}$.

${ }^{b}{ }^{* 13} \mathrm{C}$ values are measured by AMS during the ${ }^{14} \mathrm{C}$ measurement for use during the ${ }^{14} \mathrm{C}$ calculation and should not be used for dietary or paleoenvironmental interpretations. 
Laboratory Number: PRI-15-008-RDK-MF-1

Sample Identification: Salicaceae and Unidentified hardwood charcoal

Conventional AMS ${ }^{14} \mathrm{C}$ Date: $10166 \pm 33 \mathrm{RCYBP}$

1-sigma Calibrated Age Range (68.2\%): 11970-11860; 11840-11760 CAL yr. BP

2-sigma Calibrated Age Range (95.4\%): 12030-11710 CAL yr. BP

${ }^{* 13} \mathrm{C}\left({ }^{\circ}{ }_{\mathrm{oo}}\right):-25.0$ (Measured for ${ }^{14} \mathrm{C}$ calculation, not valid for dietary or paleoenvironmental interpretations)

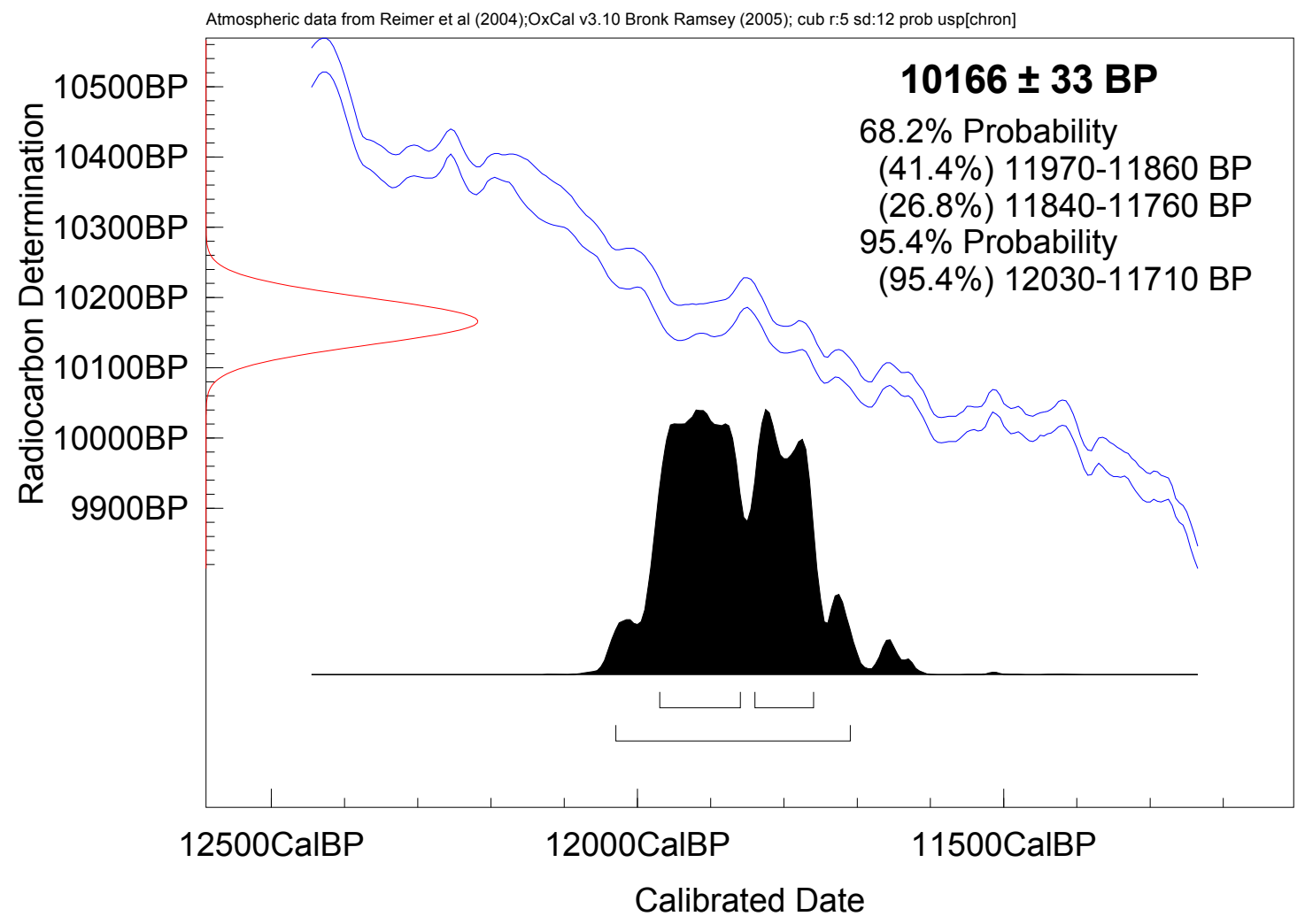

Intercept Statement. For radiocarbon calibration, PRI uses OxCal3.10 (Bronk Ramsey 2005), which is a probability-based method for converting ages in radiocarbon years (RCYBP) into calibrated dates (CAL yr $\mathrm{BP})$. This method is preferred over the intercept-based alternative because instead of providing individual point estimates, it reflects the probability of the date's occurrence within a given range (reflected by the amplitude [height] of the curve). As a result, the probability-based method produces more stable calibrated values than do intercept-based methods (Telford 2004). Ongoing refinements and adjustments to the calibration curve have a greater apparent effect on individual points than on ranges.

\section{References}

Bronk Ramsey, C., 2005, OxCal. 3.1 ed. www.rlaha.ox.ac.uk/oxcal/oxcal.htm.

Reimer, P. J., M. G. L. Baillie, E. Bard, A. Bayliss, J. W. Beck, P.G. Blackwell, C. Bronk Ramsey, C. E. Buck, G. S. Burr, R. L. Edwards, M. Friedrich, P. M. Grootes, T. P. Guilderson, I. Hajdas, T. J. Heaton, A. G. Hogg, K. A. Hughen, K. F. Kaiser, B. Kromer, F. G. McCormac, S. W. Manning, R. W. Reimer, D. A. Richards, J. R. Southon, S. Talamo, C. S. M. Turney, J. van der Plicht, C. E. Weyhenmeyer. 2009. IntCal09 and Marine09 radiocarbon age calibration curves, 0-50,000 years cal BP. Radiocarbon 51(4):1111-1150.

Telford, R. J., E. Heegaard, and H. J. B. Birks, 2004, The Holocene 14(2):296-298. 
Laboratory Number: PRI-15-008-NFT-T1-RDK4

Sample Identification: Picea charcoal

Average Lifespan: Variable, depending on species, from 150-200, up to 250 years

Conventional AMS ${ }^{14} \mathrm{C}$ Date: $4803 \pm 22 \mathrm{RCYBP}$

1-sigma Calibrated Age Range (68.2\%): 5590-5580; 5530-5480 CAL yr. BP

2-sigma Calibrated Age Range (95.4\%): 5600-5570; 5550-5470 CAL yr. BP

${ }^{*}{ }^{13} \mathrm{C}(\%)$ : -23.7 (Measured for ${ }^{14} \mathrm{C}$ calculation, not valid for dietary or paleoenvironmental interpretations)

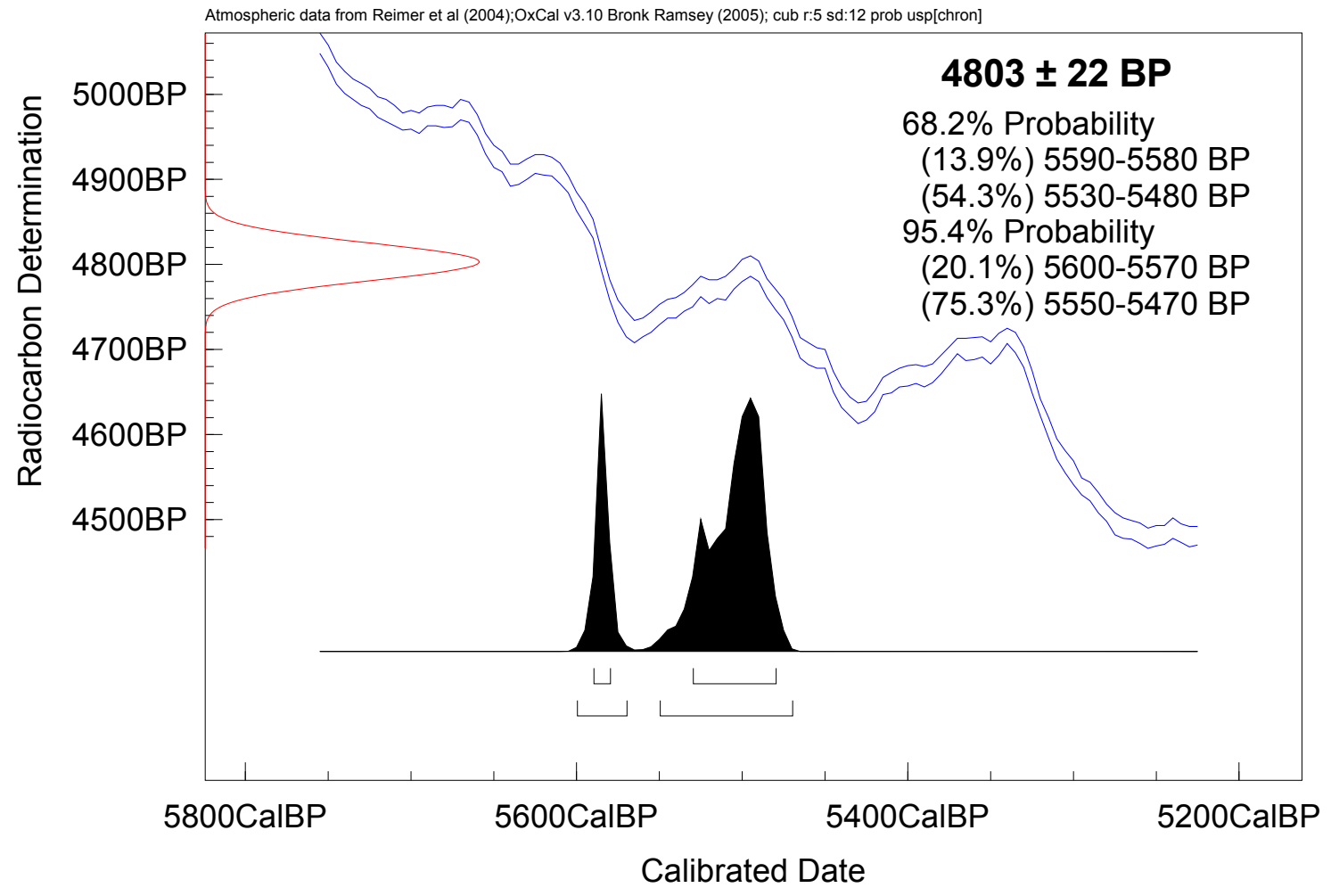

Intercept Statement. For radiocarbon calibration, PRI uses OxCal3.10 (Bronk Ramsey 2005), which is a probability-based method for converting ages in radiocarbon years (RCYBP) into calibrated dates (CAL yr $\mathrm{BP}$ ). This method is preferred over the intercept-based alternative because instead of providing individual point estimates, it reflects the probability of the date's occurrence within a given range (reflected by the amplitude [height] of the curve). As a result, the probability-based method produces more stable calibrated values than do intercept-based methods (Telford 2004). Ongoing refinements and adjustments to the calibration curve have a greater apparent effect on individual points than on ranges.

\section{References}

Bronk Ramsey, C., 2005, OxCal. 3.1 ed. www.rlaha.ox.ac.uk/oxcal/oxcal.htm.

Reimer, P. J., M. G. L. Baillie, E. Bard, A. Bayliss, J. W. Beck, P.G. Blackwell, C. Bronk Ramsey, C. E. Buck, G. S. Burr, R. L. Edwards, M. Friedrich, P. M. Grootes, T. P. Guilderson, I. Hajdas, T. J. Heaton, A. G. Hogg, K. A. Hughen, K. F. Kaiser, B. Kromer, F. G. McCormac, S. W. Manning, R. W. Reimer, D. A. Richards, J. R. Southon, S. Talamo, C. S. M. Turney, J. van der Plicht, C. E. Weyhenmeyer. 2009. IntCal09 and Marine09 radiocarbon age calibration curves, 0-50,000 years cal BP. Radiocarbon 51(4):1111-1150.

Telford, R. J., E. Heegaard, and H. J. B. Birks, 2004, The Holocene 14(2):296-298. 
Laboratory Number: PRI-15-008-NFT-T1-RDK5

Sample Identification: Picea charcoal

Average Lifespan: Variable, depending on species, from 150-200, up to 250 years

Conventional AMS ${ }^{14} \mathrm{C}$ Date: $4767 \pm 23$ RCYBP

1-sigma Calibrated Age Range (68.2\%): 5590-5570; 5550-5500; 5490-5470 CAL yr. BP

2-sigma Calibrated Age Range (95.4\%): 5590-5460 CAL yr. BP

${ }^{*}{ }^{13} \mathrm{C}(\%)$ ): -25.9 (Measured for ${ }^{14} \mathrm{C}$ calculation, not valid for dietary or paleoenvironmental interpretations)

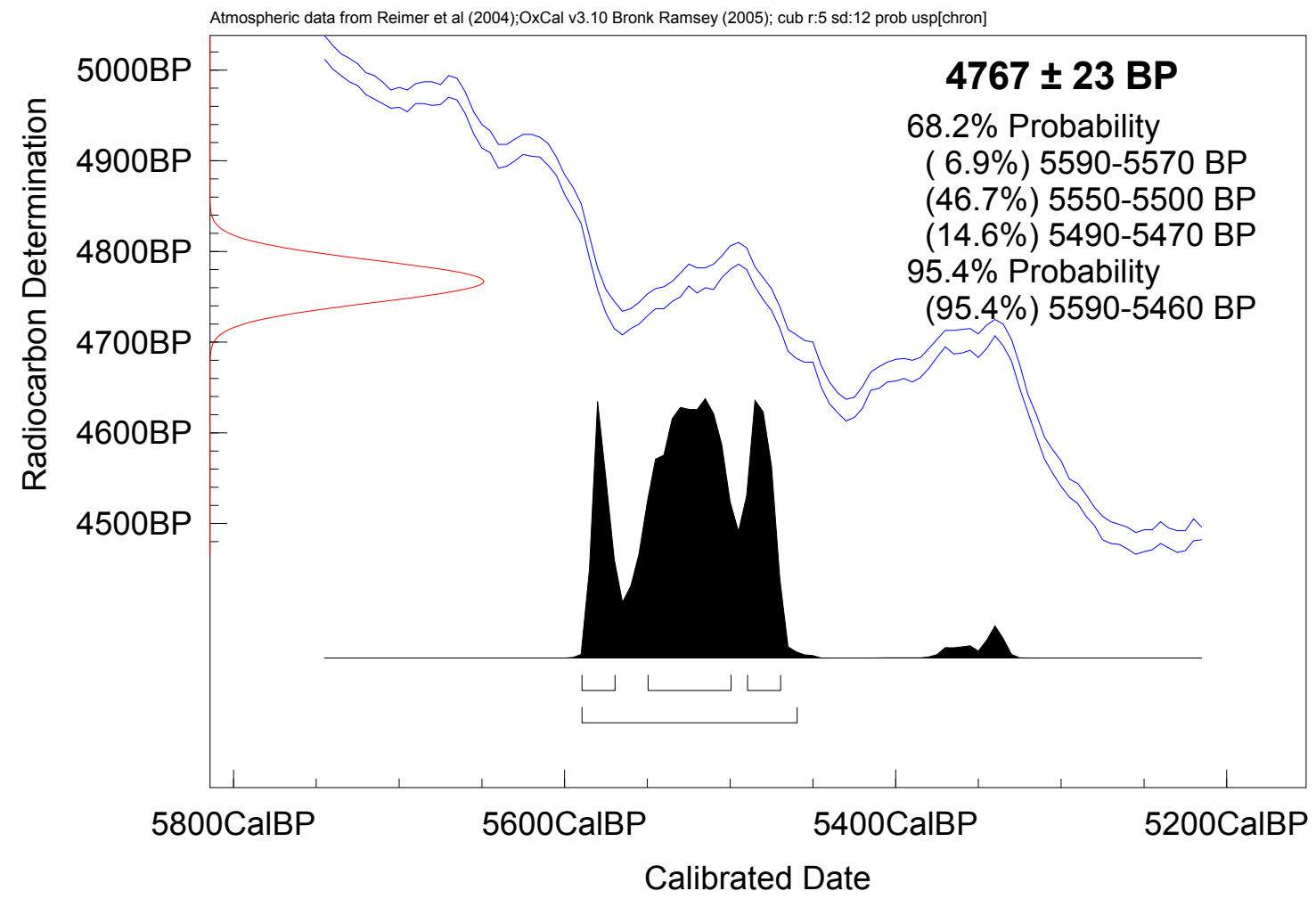

Intercept Statement. For radiocarbon calibration, PRI uses OxCal3.10 (Bronk Ramsey 2005), which is a probability-based method for converting ages in radiocarbon years (RCYBP) into calibrated dates (CAL yr $\mathrm{BP})$. This method is preferred over the intercept-based alternative because instead of providing individual point estimates, it reflects the probability of the date's occurrence within a given range (reflected by the amplitude [height] of the curve). As a result, the probability-based method produces more stable calibrated values than do intercept-based methods (Telford 2004). Ongoing refinements and adjustments to the calibration curve have a greater apparent effect on individual points than on ranges.

\section{References}

Bronk Ramsey, C., 2005, OxCal. 3.1 ed. www.rlaha.ox.ac.uk/oxcal/oxcal.htm.

Reimer, P. J., M. G. L. Baillie, E. Bard, A. Bayliss, J. W. Beck, P.G. Blackwell, C. Bronk Ramsey, C. E. Buck, G. S. Burr, R. L. Edwards, M. Friedrich, P. M. Grootes, T. P. Guilderson, I. Hajdas, T. J. Heaton, A. G. Hogg, K. A. Hughen, K. F. Kaiser, B. Kromer, F. G. McCormac, S. W. Manning, R. W. Reimer, D. A. Richards, J. R. Southon, S. Talamo, C. S. M. Turney, J. van der Plicht, C. E. Weyhenmeyer. 2009. IntCal09 and Marine09 radiocarbon age calibration curves, 0-50,000 years cal BP. Radiocarbon 51(4):1111-1150.

Telford, R. J., E. Heegaard, and H. J. B. Birks, 2004, The Holocene 14(2):296-298. 
Laboratory Number: PRI-15-008-NFT-T1-RDK1

Sample Identification: Picea charcoal

Average Lifespan: Variable, depending on species, from 150-200, up to 250 years

Conventional AMS ${ }^{14} \mathrm{C}$ Date: $2805 \pm 22 \mathrm{RCYBP}$

1-sigma Calibrated Age Range (68.2\%): 2945-2870 CAL yr. BP

2-sigma Calibrated Age Range (95.4\%): 2970-2850 CAL yr. BP

${ }^{*}{ }^{13} \mathrm{C}(\%)$ : -25.9 (Measured for ${ }^{14} \mathrm{C}$ calculation, not valid for dietary or paleoenvironmental interpretations)

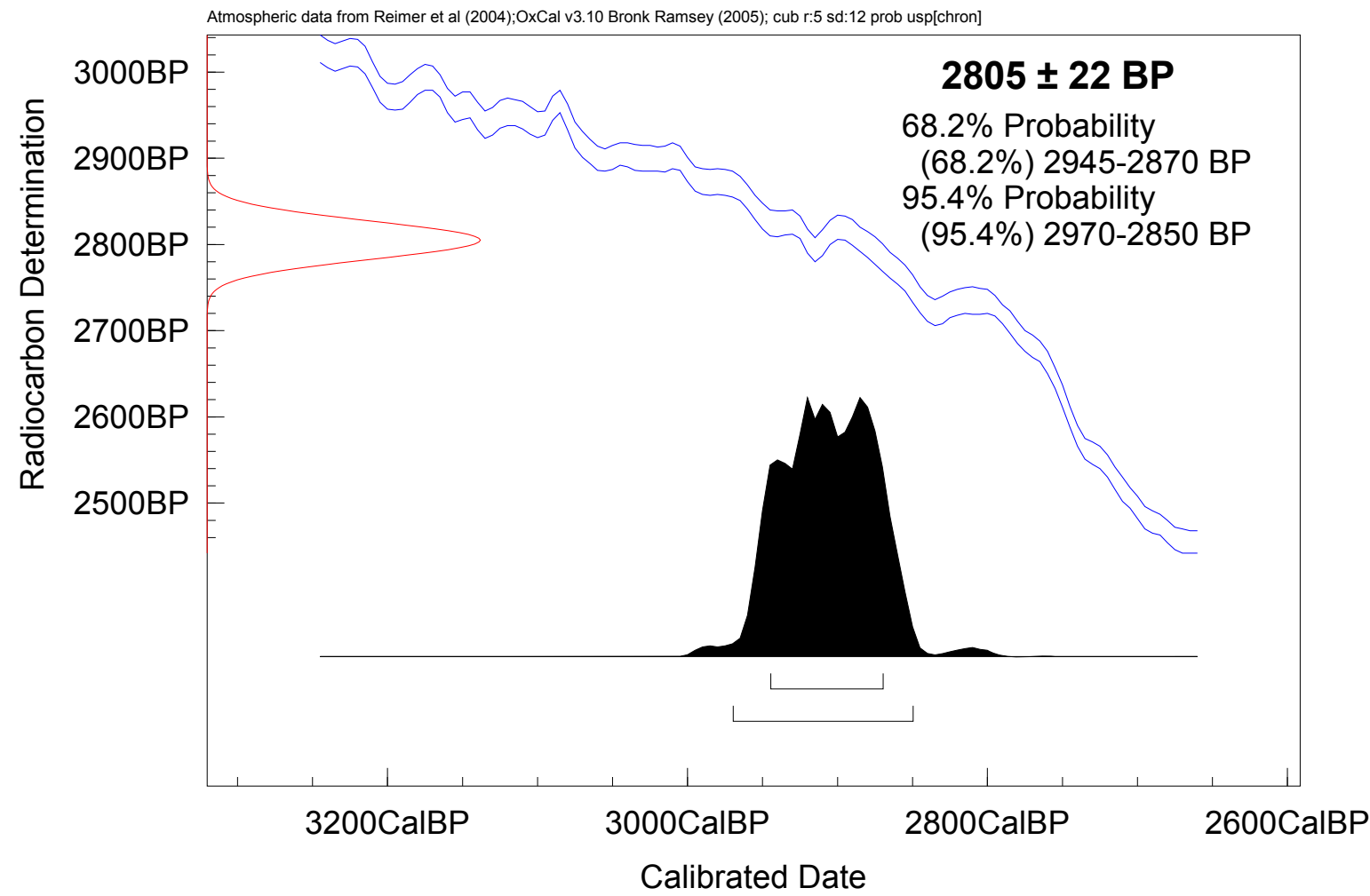

Intercept Statement. For radiocarbon calibration, PRI uses OxCal3.10 (Bronk Ramsey 2005), which is a probability-based method for converting ages in radiocarbon years (RCYBP) into calibrated dates (CAL yr $\mathrm{BP}$ ). This method is preferred over the intercept-based alternative because instead of providing individual point estimates, it reflects the probability of the date's occurrence within a given range (reflected by the amplitude [height] of the curve). As a result, the probability-based method produces more stable calibrated values than do intercept-based methods (Telford 2004). Ongoing refinements and adjustments to the calibration curve have a greater apparent effect on individual points than on ranges.

\section{References}

Bronk Ramsey, C., 2005, OxCal. 3.1 ed. www.rlaha.ox.ac.uk/oxcal/oxcal.htm.

Reimer, P. J., M. G. L. Baillie, E. Bard, A. Bayliss, J. W. Beck, P.G. Blackwell, C. Bronk Ramsey, C. E. Buck, G. S. Burr, R. L. Edwards, M. Friedrich, P. M. Grootes, T. P. Guilderson, I. Hajdas, T. J. Heaton, A. G. Hogg, K. A. Hughen, K. F. Kaiser, B. Kromer, F. G. McCormac, S. W. Manning, R. W. Reimer, D. A. Richards, J. R. Southon, S. Talamo, C. S. M. Turney, J. van der Plicht, C. E. Weyhenmeyer. 2009. IntCal09 and Marine09 radiocarbon age calibration curves, 0-50,000 years cal BP. Radiocarbon 51(4):1111-1150.

Telford, R. J., E. Heegaard, and H. J. B. Birks, 2004, The Holocene 14(2):296-298. 
Laboratory Number: PRI-15-008-NFT-T1-RDK3

Sample Identification: Picea charcoal

Average Lifespan: Variable, depending on species, from 150-200, up to 250 years

Conventional AMS ${ }^{14} \mathrm{C}$ Date: $3209 \pm 22 \mathrm{RCYBP}$

1-sigma Calibrated Age Range (68.2\%): 3450-3400 CAL yr. BP

2-sigma Calibrated Age Range (95.4\%): 3470-3380 CAL yr. BP

${ }^{*}{ }^{13} \mathrm{C}(\%)$ ):-23.4 (Measured for ${ }^{14} \mathrm{C}$ calculation, not valid for dietary or paleoenvironmental interpretations)

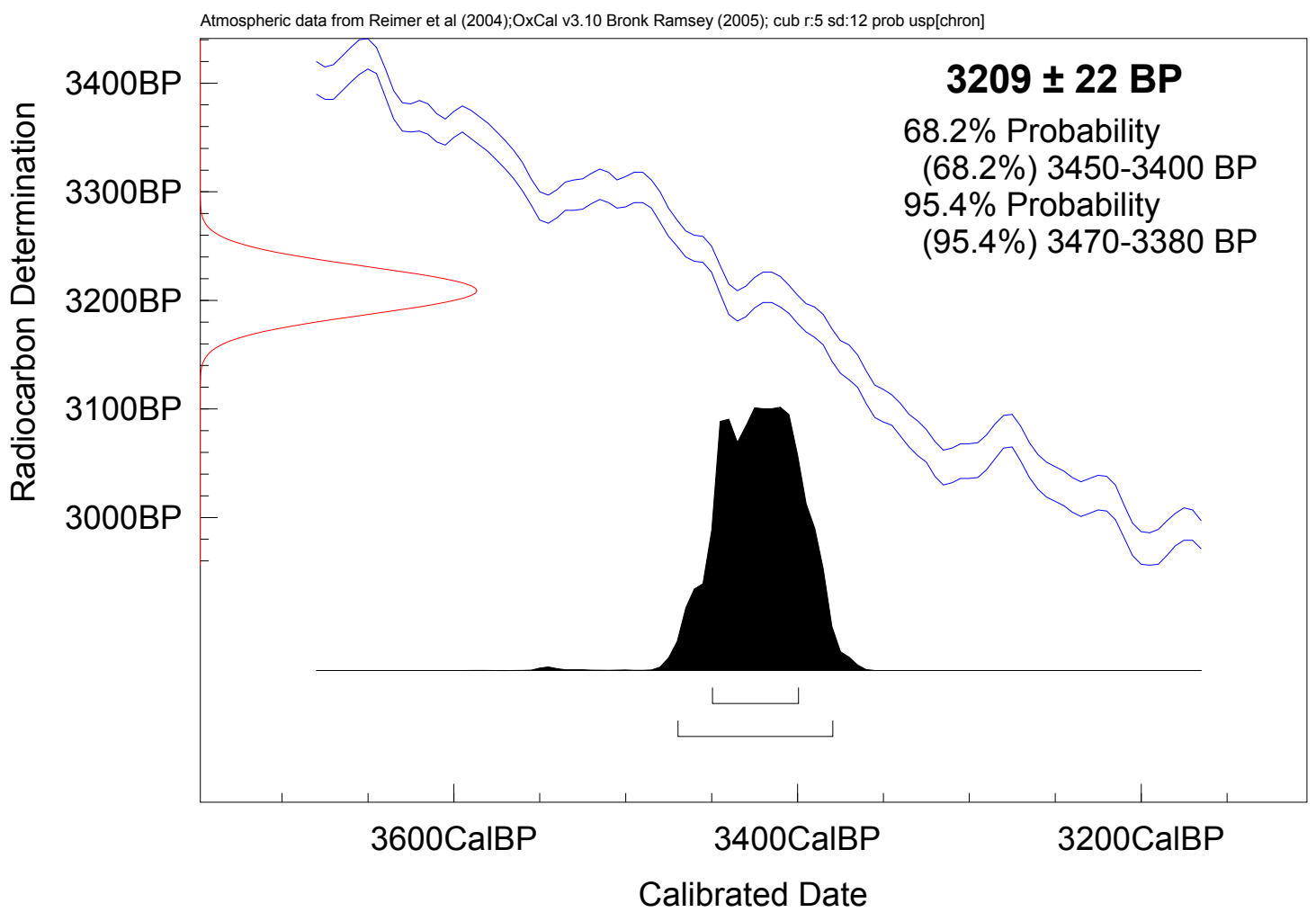

Intercept Statement. For radiocarbon calibration, PRI uses OxCal3.10 (Bronk Ramsey 2005), which is a probability-based method for converting ages in radiocarbon years (RCYBP) into calibrated dates (CAL yr $\mathrm{BP})$. This method is preferred over the intercept-based alternative because instead of providing individual point estimates, it reflects the probability of the date's occurrence within a given range (reflected by the amplitude [height] of the curve). As a result, the probability-based method produces more stable calibrated values than do intercept-based methods (Telford 2004). Ongoing refinements and adjustments to the calibration curve have a greater apparent effect on individual points than on ranges.

\section{References}

Bronk Ramsey, C., 2005, OxCal. 3.1 ed. www.rlaha.ox.ac.uk/oxcal/oxcal.htm.

Reimer, P. J., M. G. L. Baillie, E. Bard, A. Bayliss, J. W. Beck, P.G. Blackwell, C. Bronk Ramsey, C. E. Buck, G. S. Burr, R. L. Edwards, M. Friedrich, P. M. Grootes, T. P. Guilderson, I. Hajdas, T. J. Heaton, A. G. Hogg, K. A. Hughen, K. F. Kaiser, B. Kromer, F. G. McCormac, S. W. Manning, R. W. Reimer, D. A. Richards, J. R. Southon, S. Talamo, C. S. M. Turney, J. van der Plicht, C. E. Weyhenmeyer. 2009. IntCal09 and Marine09 radiocarbon age calibration curves, 0-50,000 years cal BP. Radiocarbon 51(4):1111-1150.

Telford, R. J., E. Heegaard, and H. J. B. Birks, 2004, The Holocene 14(2):296-298. 
PRI RADIOCARBON AGE CALIBRATION FOR SAMPLE PRI-15-008-RDK-CMF-RC2

Laboratory Number: PRI-15-008-RDK-CMF-RC2

Sample Identification: Arctostaphylos seed, charred

Conventional AMS ${ }^{14} \mathrm{C}$ Date: $10205 \pm 34$ RCYBP

1-sigma Calibrated Age Range (68.2\%): 12030-11950; 11930-11820 CAL yr. BP

2-sigma Calibrated Age Range (95.4\%): 12060-11760 CAL yr. BP

${ }^{*}{ }^{13} \mathrm{C}\left(\%{ }_{\mathrm{oo}}\right):-21.5$ (Measured for ${ }^{14} \mathrm{C}$ calculation, not valid for dietary or paleoenvironmental interpretations)

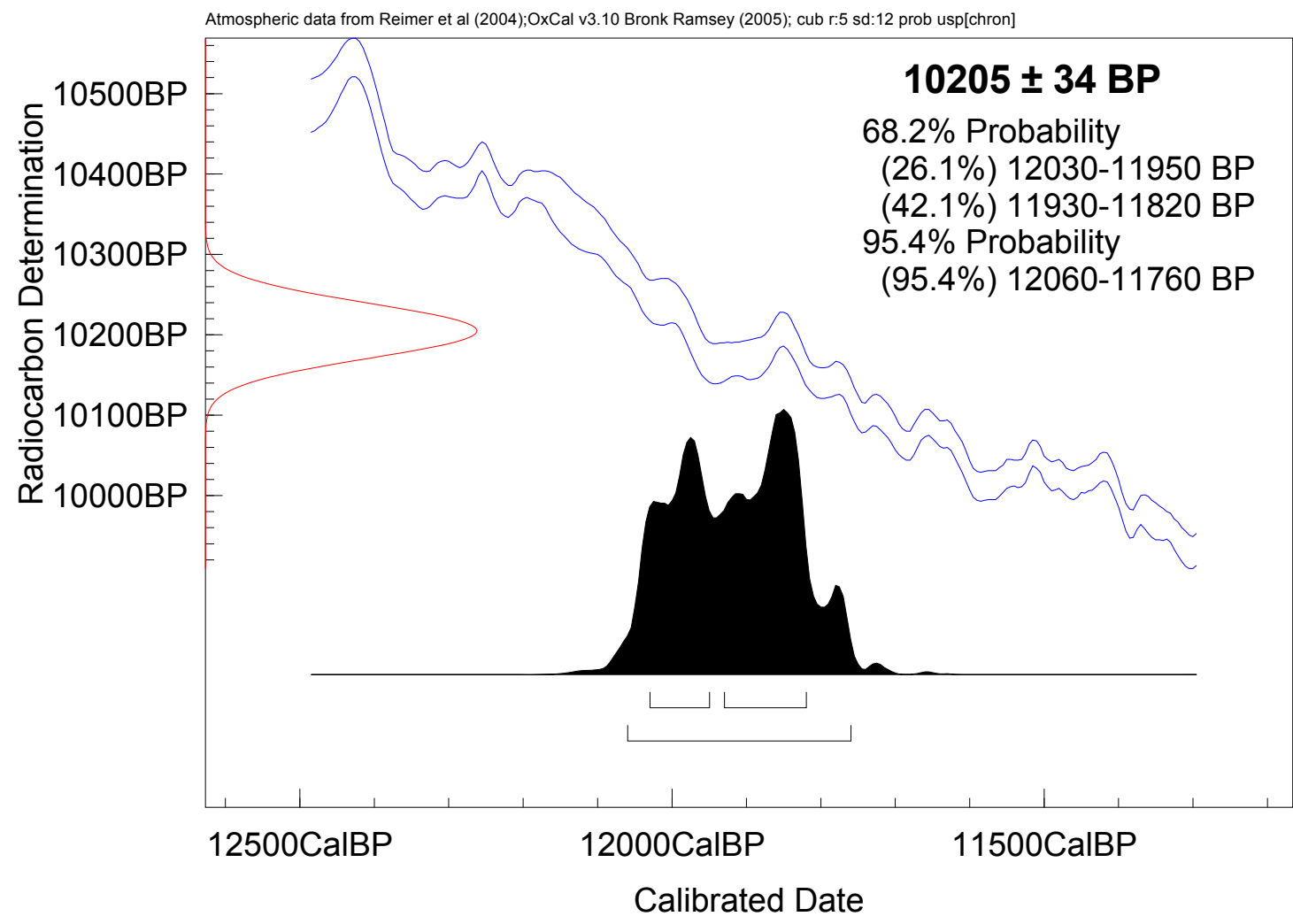

Intercept Statement. For radiocarbon calibration, PRI uses OxCal3.10 (Bronk Ramsey 2005), which is a probability-based method for converting ages in radiocarbon years (RCYBP) into calibrated dates (CAL yr $\mathrm{BP}$ ). This method is preferred over the intercept-based alternative because instead of providing individual point estimates, it reflects the probability of the date's occurrence within a given range (reflected by the amplitude [height] of the curve). As a result, the probability-based method produces more stable calibrated values than do intercept-based methods (Telford 2004). Ongoing refinements and adjustments to the calibration curve have a greater apparent effect on individual points than on ranges.

\section{References}

Bronk Ramsey, C., 2005, OxCal. 3.1 ed. www.rlaha.ox.ac.uk/oxcal/oxcal.htm.

Reimer, P. J., M. G. L. Baillie, E. Bard, A. Bayliss, J. W. Beck, P.G. Blackwell, C. Bronk Ramsey, C. E. Buck, G. S. Burr, R. L. Edwards, M. Friedrich, P. M. Grootes, T. P. Guilderson, I. Hajdas, T. J. Heaton, A. G. Hogg, K. A. Hughen, K. F. Kaiser, B. Kromer, F. G. McCormac, S. W. Manning, R. W. Reimer, D. A. Richards, J. R. Southon, S. Talamo, C. S. M. Turney, J. van der Plicht, C. E. Weyhenmeyer. 2009. IntCal09 and Marine09 radiocarbon age calibration curves, 0-50,000 years cal BP. Radiocarbon 51(4):1111-1150.

Telford, R. J., E. Heegaard, and H. J. B. Birks, 2004, The Holocene 14(2):296-298. 
Laboratory Number: PRI-15-008-RDK-CMF-RC1

Sample Identification: Unidentified seed, vitrified

Conventional AMS ${ }^{14} \mathrm{C}$ Date: $10306 \pm 32$ RCYBP

1-sigma Calibrated Age Range (68.2\%): 12160-12030 CAL yr. BP

2-sigma Calibrated Age Range (95.4\%): 12360-12310; 12300-12270; 12240-11970 CAL yr. BP

${ }^{*}{ }^{13} \mathrm{C}(\%)$ : -24.6 (Measured for ${ }^{14} \mathrm{C}$ calculation, not valid for dietary or paleoenvironmental interpretations)

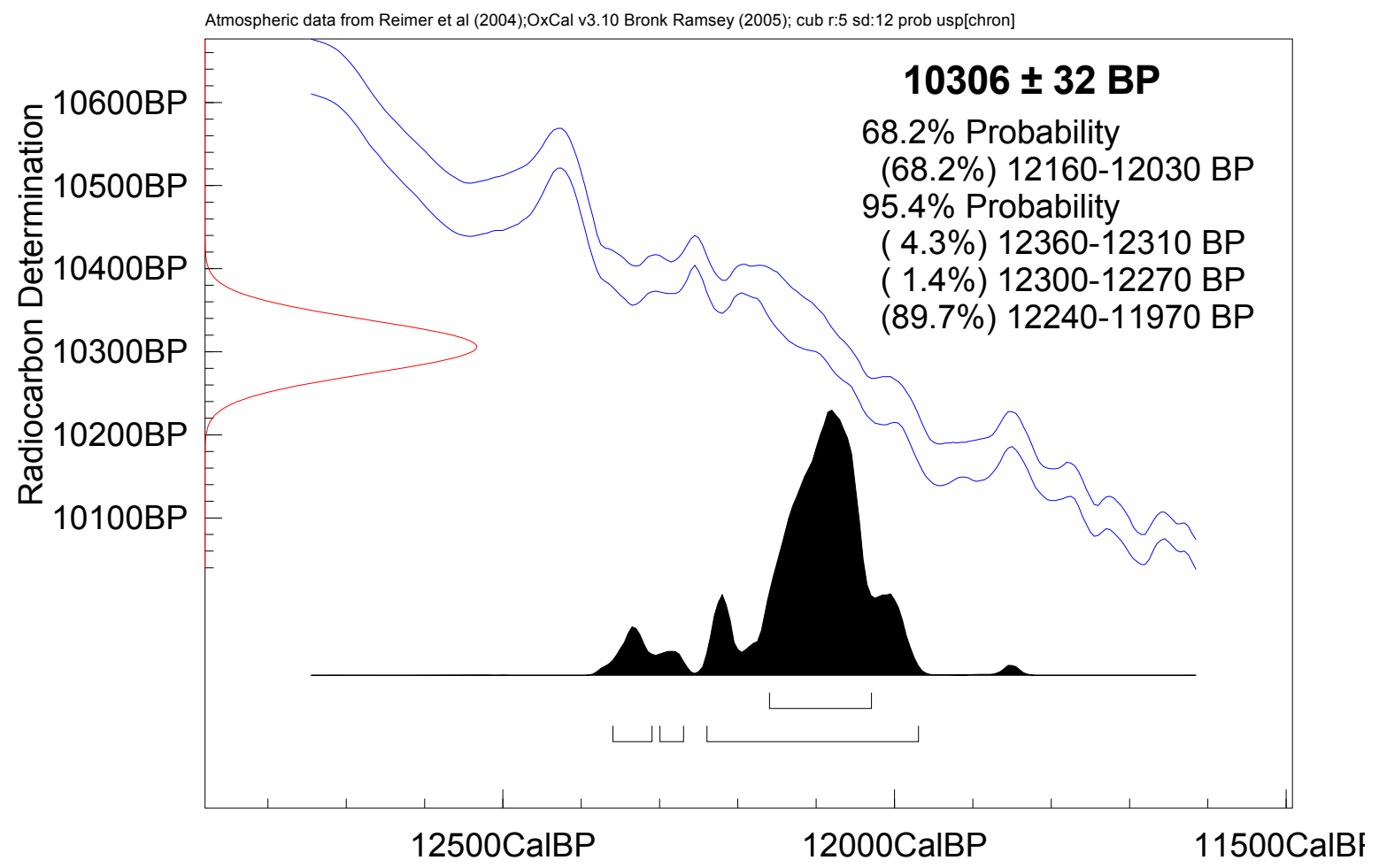

Calibrated Date

Intercept Statement. For radiocarbon calibration, PRI uses OxCal3.10 (Bronk Ramsey 2005), which is a probability-based method for converting ages in radiocarbon years (RCYBP) into calibrated dates (CAL yr $\mathrm{BP}$ ). This method is preferred over the intercept-based alternative because instead of providing individual point estimates, it reflects the probability of the date's occurrence within a given range (reflected by the amplitude [height] of the curve). As a result, the probability-based method produces more stable calibrated values than do intercept-based methods (Telford 2004). Ongoing refinements and adjustments to the calibration curve have a greater apparent effect on individual points than on ranges.

\section{References}

Bronk Ramsey, C., 2005, OxCal. 3.1 ed. www.rlaha.ox.ac.uk/oxcal/oxcal.htm.

Reimer, P. J., M. G. L. Baillie, E. Bard, A. Bayliss, J. W. Beck, P.G. Blackwell, C. Bronk Ramsey, C. E. Buck, G. S. Burr, R. L. Edwards, M. Friedrich, P. M. Grootes, T. P. Guilderson, I. Hajdas, T. J. Heaton, A. G. Hogg, K. A. Hughen, K. F. Kaiser, B. Kromer, F. G. McCormac, S. W. Manning, R. W. Reimer, D. A. Richards, J. R. Southon, S. Talamo, C. S. M. Turney, J. van der Plicht, C. E. Weyhenmeyer. 2009. IntCal09 and Marine09 radiocarbon age calibration curves, 0-50,000 years cal BP. Radiocarbon 51(4):1111-1150.

Telford, R. J., E. Heegaard, and H. J. B. Birks, 2004, The Holocene 14(2):296-298. 